\title{
ATTRACTION TO AND SELECTION OF PREY BY \\ MMATURE LOBSTERS (HOMARUS AMERICANUS)
}

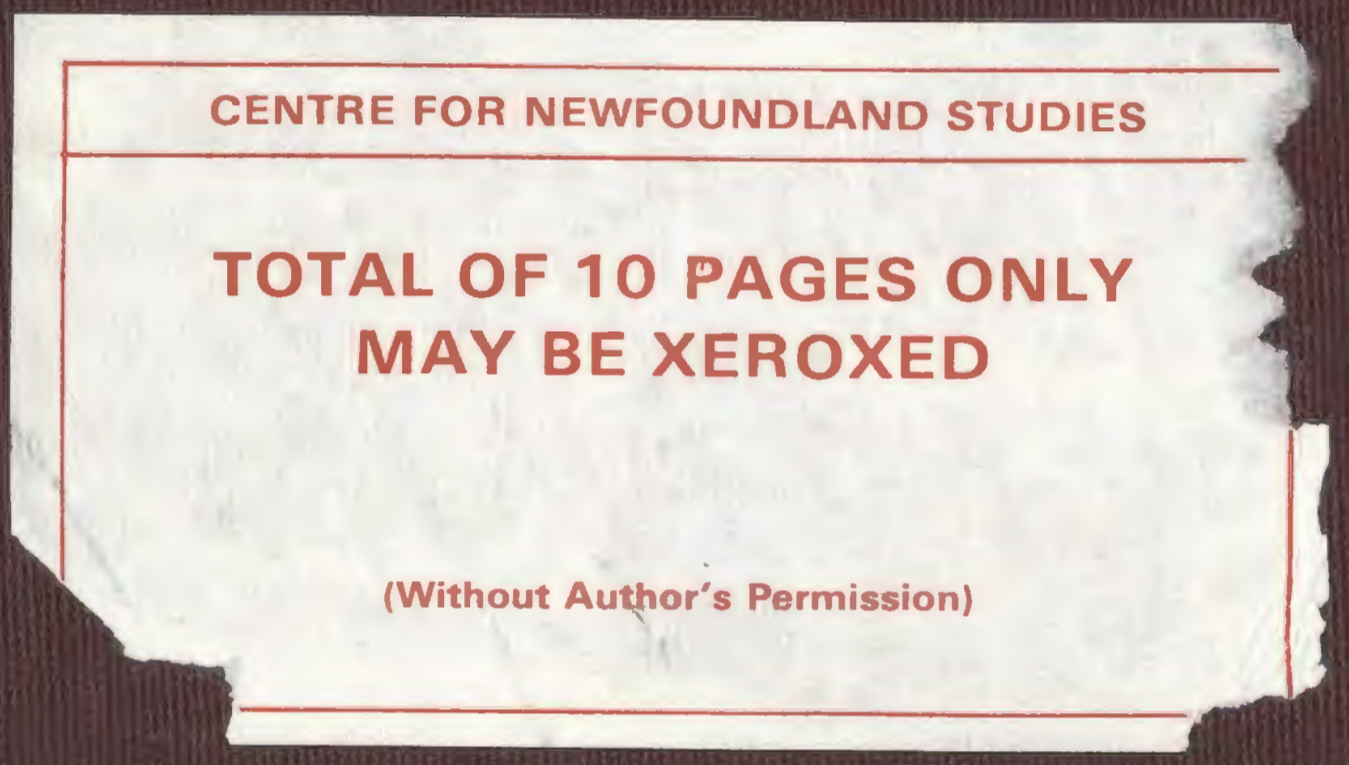

JOHN ANDREW CARTER 



$$
00132
$$

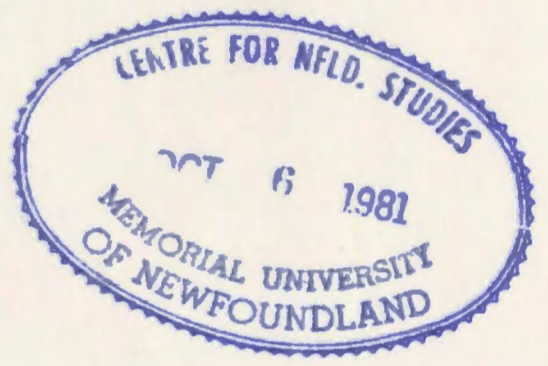



National Library of Canada

Coillections Developritent'Branch

Canadian Theses on

Microfiche Service
Bibliotheque nationale du Canada

Drection du développement des collections

Servjce des theses canadiennes sur microfiche.
NOTICE

The quality of this microfiche is heavily dependerit upor the quality 'of the original thesis submitted for. microfilming: Every effort has beên made to ensure the highest quality of reprodiction possible. .

'If pages are missing, contact the university which granted the degree.

Some pages may have indistinct print especialdv if the original pages were typed "with a poor typewriter ribbon or if the university sent us a poor photocopy.

Previously copyrighted materials (journal, articles, published tests, etç.) àre not filmed.

Reproduction in full or in part of this film is governed by the Canadian Copyright Act, R.S.C. 1970, c. C-30. 'Please read the authorization forms which accompany this thesis.

\section{AVIS}

La qualité de cette microfiche dépend grandement de la qualité de la thèse, soumise au microfilmage. Nous avons tout falt pour assurer une qualité supérieure de reproduction.

'S'it" manque des" pages, veuillez communiquer avec l'université qui a conféré le grade".

La qualité dimpressioh de certaines pages peut láisser à désirer, surtout si les pages originales ont étê "dactylographiées à l'aide d'un ruban usé ou si l'univer. site nous a fait parvenir unfe photocopie de 'maúvaise qualité.

Les documents "qưi font déjà l'objet d'un droit d'auteur (articles de revue, examens, publiés, etc.) ne soñt pas microfilmés. :

La reproduction, même partielle de ce microfilm est soumise à la Li canadienne sur le drait d'auteur, SRC 1970, c. C-30. Veuillez prendre connaíssance des formules d'autorisation qui accompagnent cette thèse.

\section{THIS DISSERTATION HAS BEEN "MICROFILMED EXACTLY AS' RECEIVED}

\section{LA THESE A. ÉTÉ MICROFILMÉE TÉLLE QUUE NOUS L'AVONS, RECUE}




\section{ATTRACTION TO AND SELECTION OF PREY}

\section{BY' IMMATURE LOBSTEERS (HOMARUS AMERICANUS)}

by

(1) John Andrew Carter B Sc

A thesis submitted in partial fulfilinent

of the requiremints for the degree of Master of Science

Department of Biology

Memorial University of Newfoundiand 
Little is known of the diet of inmature lobsters chomarus americanus). Attraction to and selection of prey by inimature lobsters in Newfoundland were the subject of the present study:

The relative attractiveness of extracts of Asterias vulgaris, Cancer irroratus; Mytilus edui is, and Strongylocentrotus droebachien's is werc determined by obsẹrving behaviour of immature lobsters. All extracts, except that of Asterias, were attractive to imnature lobsters Cancer was preferred over Mytilus and the two echinodern species Imature lobsters were subjected to metabolites of prey. Most lobsters showed alert phase behaviour regardiess of the quality of the stimulus cancer ef fiuent wa significantly more effective than controls in eliciting foodsearching behaviour Mytilus and Strongylocentrotus effluents were Iess effective stimulants

The percentage responses of inmature lobsters presented with. ninhydrin-positive compouthd (NPC) targets were determined Proline, ammonia, arginine, and 1ysine were the most attractive NPCs. The NPC compositions of effluents and extracts of various prey were detemined. Extracts of Nereis sp. and Cancer irroratus had the highest total concen trations of NPCs (excluding urea, unknowns polyamines, and trace amounts) Cancer had significartly higher concentrations of glutamine, proline, and taurine compared to Asterias and Strongyiocentrotus Effluents of Nereis arid Cancer had higher levels of ammonia than those of three echinoderm and two mollusc species.

Selection of intact prey by immature lobsters given a choice was deternined Brittlestars and polychaetes we the most frequently at ! 
tacked, followed by Cancer, Asterias, Mytilus, and strongylocentrotus

Consumption of polychaétes by imature lobsters was generally complete. Substantiliy greater proportions of the ofther prey species were 1eft unconsimed Size, morphology, and behaviour of prey appeared to infiuence the attack rates:

$+1$

The natural diet of immature Iobsters was determined by gut content analysis Sea urchìns, mussês and crabs were frequenticy consumed Cancer was the dominant item in terms of volume of gut contents seasorial differences in feeding behaviour of inature lobsters were observed $\mathrm{E}$ lectivity indices indicated a high selection of crabs and mussels by im mature lobsters:

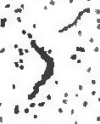


It is very cautious and cunning, capturing its prey by stealth, and with weapons which it lowows how to conceal. Lying hidden in a buch 'of seaweed, in a crevice anong the rocks,or in its' burrow'in the mud, it waits unitil its ictin is within reach of its claws before striking the fatàl blow.
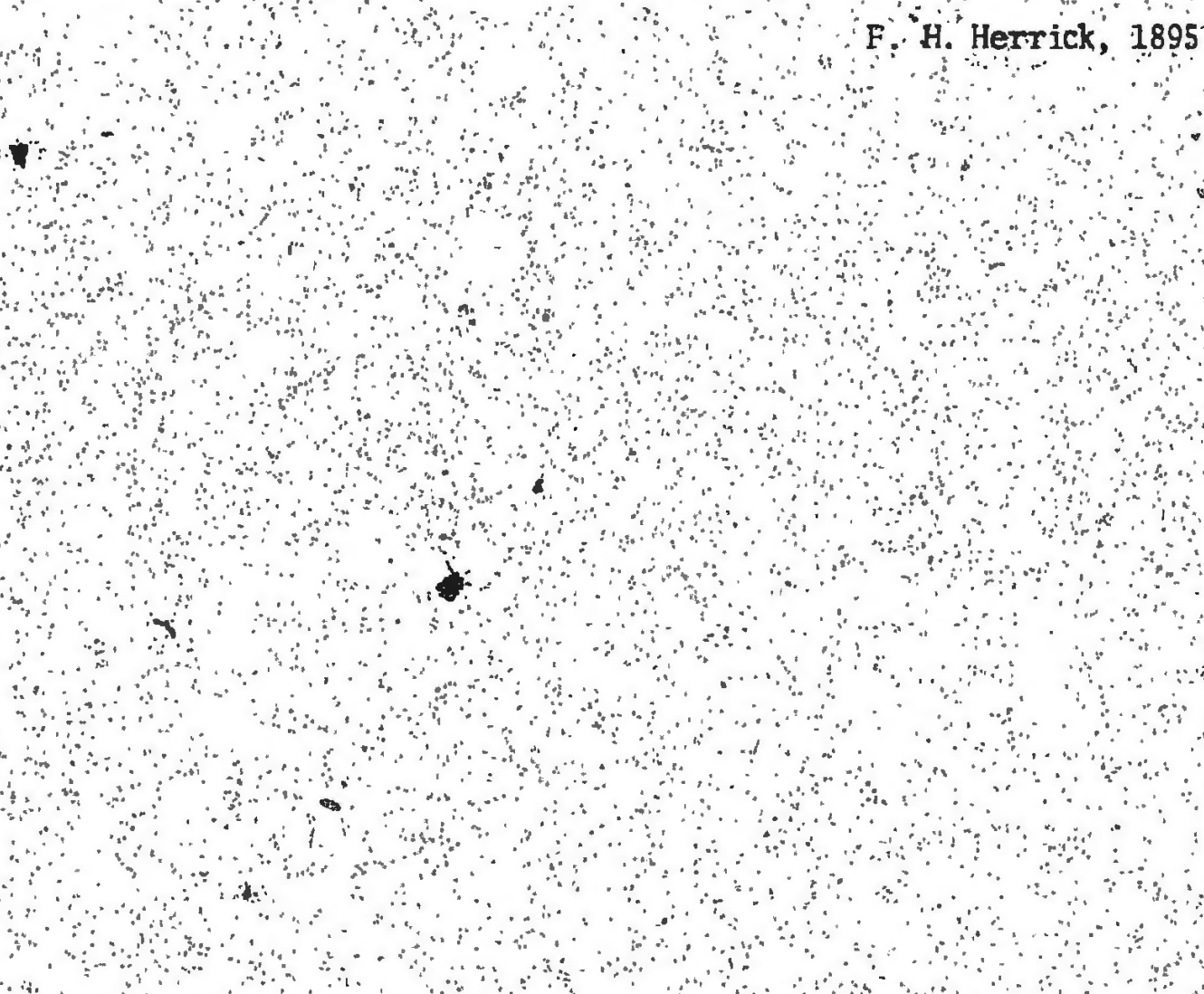
I thank Dr. D H Steele for helpful coments on the experimental phases of this study and preparation of the manuscript. I would like to acknowledge as well the ass istance of Drs. J Green and Cavis in revision of the manuscript.

Robert Fisher generously assisted on all diving aspects of this study and helped with the photography His contribution to this thes is is greatly appreciated. Doug Hali conducted the NPC analyses and Róy Ficken printed the photographs I would like to thank Gary Dumphy for many discussions on a wide range of topics, and Tom Brewer and Roy Lockyer, the crew of the Elsie $G$ for their assistance Al the personnel of the Marine Sciences Research Laboratory were most generous with their tive and equipment.

Finally, I would like to acknowledge the financial assistance in the form of a University Fel lowship, from Memorial University. 


\section{TABLE OF CONTENTS}

Page No.

ABSTRACT

ACKNOWLEDGEMENTS

LIST OF TABLES

LIST OF " FİGURES

INTRODUCTION

MATERIALS AND METHODS

Collection and holding conditions

5.

Attraction to prey extracts

7

Attraction to prey effiuents.

Attraction to nithydrin positive compounds (NPCs)

Analysis of NPCs in prey tissue extracts and

14 .

on

effluents

16.

Controlled prey selection

Gut content analysïs

18 .

Prey density in Placentia Bay

20.

RESULTS

Attraction to prey extracts

22

Attraction to prey effluents

32.

Attraction to ninhydrin positive compounds (NPCs)

34.

Analysis of NPCs in prey tissue extracts and

36.

effluents

Controlled prey selectión

40.

Gut content analysis

48.

Prey density, in Placentia Bay

65 .

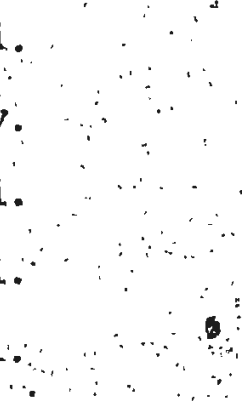




\section{(G) TABLE OF CONTENSS CONT'D.}

Page No:

\section{DISCUSSION}

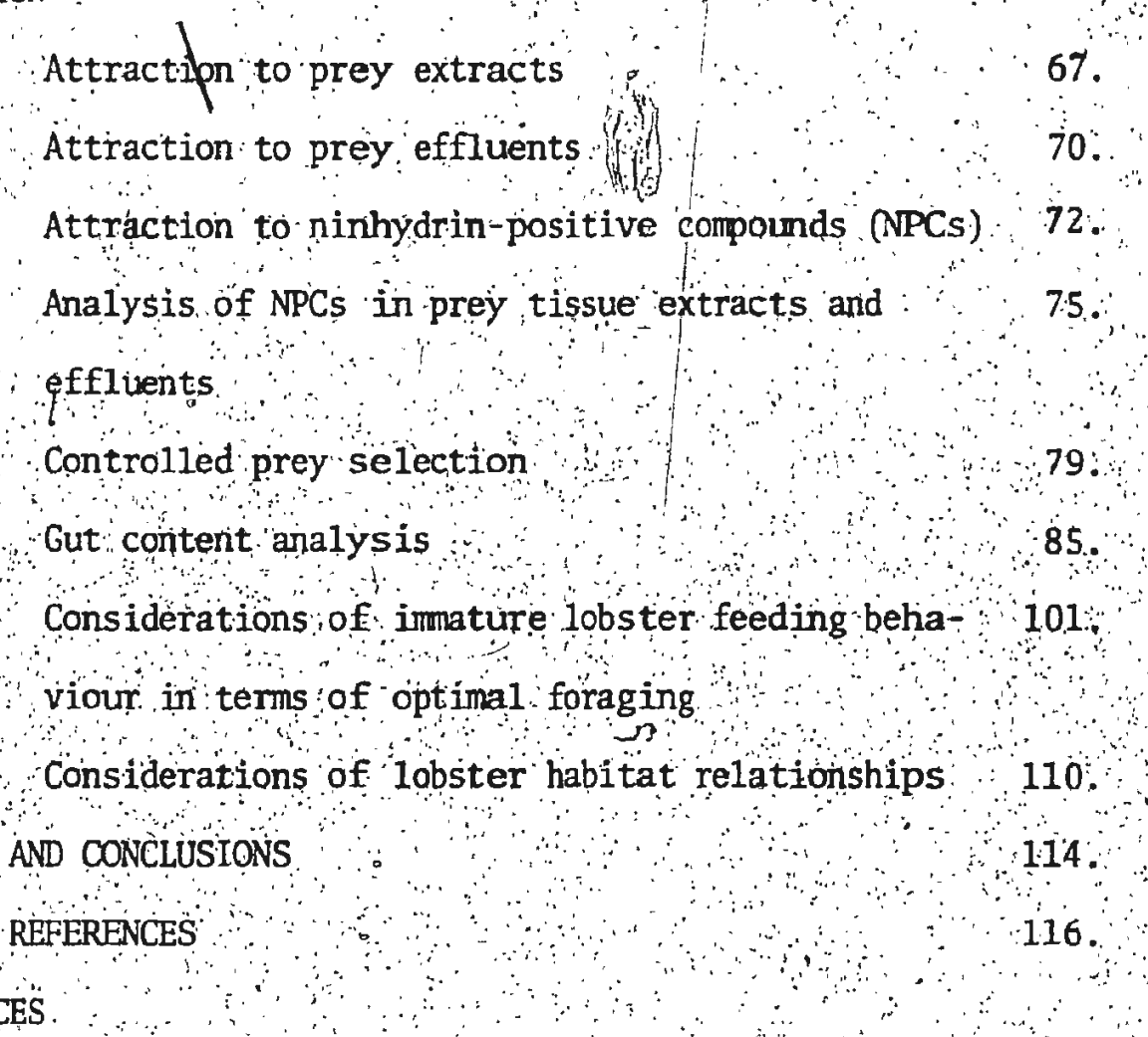

APPENDIX A. Individual lobster data at time of 124 colilection

APPENDIX B. Free ninhydrin-positive compound (NPC) concentrations of prey or-

1 ganism tissue extracts

APPENDIX Gut items of imature lobstèrs

130

(Homarus americanus) characteristic hard parts

APPENDIX D. Percentage of umature lobsters

132. 



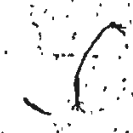

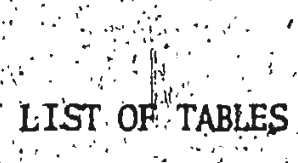

vili-

Page No:

Table 1 Responses of immature lobsters (H. americanus) 26. to prey extracts

Table 2 Paired comparison $\mathrm{F}$ values for responses of im- 24 mature lobsters (H americanus to prey extracts

Table 3 Percentage of inature lobsters (1- americanus) ex-29. hibiting food-searching response to prey extracts

Table 4 . Percentage of imature Iobsters (H americanus) 30 moving to and exhibiting food-searching response at the stimuilus origin

Table 5 Percentagé of imature lobsters (H afericanus $) \quad 31$ in which prey extracts elicited the greatest food-searching response

Table 6. Percentage of imature lobsters (H. americanus) 33. showing types of behaviour elicited by prey effiuents

Table 7 Perentage frequency of NPC target captures by imature lobsters. ( $\mathrm{H}$. americanus)

Table 8 Mean concentrations of free ninhydrin-positive cơmpounds (NPCs) of prey tissue extracts as a percentage of tota1 NPC concentration

Table 9 Mean ninhydrin positive compound. (NPC) concen-

$39=$ trations of prey effluents ir seawater

Table 10. Percentage frequency of attack of various prey 41. organisms by immature lobsters (H. americanus)

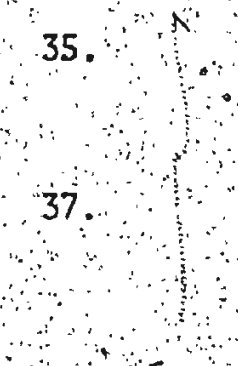


LIST OF TABLES CONT D.

Page $N 0^{\circ}$

Table 11: Ratios of weight of prey residues to wet weight

42. of prey attacked by inmature lobsters $\mathrm{H}$ amer

( icanus)

Tab1e 12 Consuintion efficiency of immature lobsters (H. americanus) offered various prey organisms

Table 13. Sizes of attacked and ignored prey organisms as 45 a percentage of innature lobster (H americanus) wet "weight

Table 14. Percentage frequency of occurrence of 1tems in guts of imatire lobsters (H. americanus) from Placentia Bay in sumier and fall

Table 15. Estimat contributions of prey items to the 52. imature lobster $(H$ americanus diet

Table 16. Seasonal differences in percentage frequency $54:$ of occurrence of gut itens of inmature lobsters (H. americanus) frớn Placènt la Bay

Table 17. Various estimates of gut fullness of imature 56 lobsters (Af americanus) from Placentia Bay by season

Tabie 18. Residency of prey hard parts in guts of inmature lobsters (H. americanus)

Table 19. Clearance of gut contents of imature lobsters. 58. ious estimates of gut fulliness

\section{(H anericanus at $8^{\circ}$ as undicated byr-}



LIST OF FIGURES

Page No.

Figure 1.ר Placentia Bay collection sites of immature lob-

6. sters (ㅂ. amerieanus)

Figure 2. Schenftic diagram of olfaction apparatus used

8. to observe attraction of inmature lobsters (H. americanus) to prey extracts

Figure 3.: Portion of kymograph record of an inmature 1obster (H. americanus) responding to extract of Asterias

Figure 4a". Typical attitude of an imnature lobster (H. amer24. icanus) during an exploratory foray

Figure 4b. Typical attitude of an immature lobster (H: amer 24 icanus) showing food-searching behaviour

Figure 5. Remains of Mytilus edulis after feeding by an 46. immature lobster $(\underline{H}$. americanus)

Figure 6. Remains of Cancer irroratus after feeding by 47. an imnature lobster (ㅂ. americanus)

Figure 7. Remains of Strongylocentrotus droebachiensis 49. after feeding by an imature lobster (H. americanus)

Figure 8. Estimated percentage contribution of the main taxonomic groups to the total volume of the innature lobster (H. americanus) population diet 
LISTT OF FIGURES CONT'D.

Page No.

Figure 9. Gut contents of an inmature lobster (H. amer-

59. icanus) with a high incidence of remains of Ophiopholis aculeata

Figure 10. Gut contents of an immature lobster (ㅂ. 60. icanus) with opercula of Littorina littorea and remains of Cancer

Figure 11. Gut contents of an imiature lobster (H: amer61. icanusj with a high incidence of Cancer irro: ratus remains

Figure 12. Gut contents of an inmature lobster $\mathrm{H}$ americanus) with a high incidence of lobster exuviae

Figure 13. Gut contents of an immature lobster (H. amer63. icanus) recently feeding on Mytilus edulis

Figure 14. Gut contents of a recently moulted immature 64. lobster (H. :mericanus) with a high incidence of Cancer remains and molluse shells

Figure 15. Relative Volume contributions of prey species to the imature lobster (H americanus) population diet. 


\section{INTRODUCT ION}

The American lobster, Homarus americanus Milne-Edwards, is one of the most important invertebrate predators of the east coast of North America. It occurs in the inshore subtidal zone and on offshore banks froit North Carolina to southern Labrador (Templeman, 1940). In the middle of this:range (Maine, Nova Scotia, and Gulf of St..Lawrence), the lobster is subject to an important commercial fișhery: In Newfoundland; apart from the west coast," small lobster fisheries are generally concentrated in Fortune Bay; Placentia Bay, Bonavista Bay, and Notre Dame Bay (Ennis, 1974)

Because of the commercial importance of the lobster, there has been arge number of studies on the animal since Herrick (1895) described its habits and development. Most have been concerned with fishery aspects, al though studies of lobster feeding behaviour and habitat relationships are becoming increasingly common (Reddin; 1973; Breen, $-1974 ;$ Breen and Mann, 1976; Evans, 1976; Ëvans and Mann, 1977; Mann, 1977; ; Hirtle and Mann, 1978):

Knowledge of the feeding habits of the lobster has been enhanced considerably in the last eighty years. Herrick (1895) described the lobster as cautious and cunning, sometimes capturing its prey by stealth; al though he suggested that the lobster is basically a scavenger feeding on dead fish. Later analyses of gut contents dispelied the idea that lobsters are scavengers. Squires and Ennis (1968), Squires (1970), Weiss (1970). Miller et al. (1971); and Ennis (1973) demonstrated a wide range of invertebrate prey in lobster guts and sugges, ted that lobsters probably: take prey more or less in proportion to their natural availability. This 
assumption is an integral part of hypotheses of lobster - sea urchin kelp associations in eaștern Canada. These hypotheses implicate the lob: ster as a key predator of sea urchins and a possible ultimate control of ke1p beds which are grazed by urchins (Mann and Breen, 1972; Breen, 1974; Breen and Mann, 1976; Mainn, 1977).

Studies of prey selection by adult lobsters suggest that. the nature of lobster predation is complicated by innate food preferences, (Reddin, 1973; Evans, 1976; Evans and Mann, 1977; Hirtle and Mann, 1978). Lobsters generally show a preference for erabs and a maller attraction to mussels and sea turchins. Evans (1976) suggested that the evidence for prey preference in adult lobsters may force a re-evaluation of hypotheses of Tobster sea urchin interactions in east cóst kelp beds

The mechanisms of food attraction in the lobster have been studied by various people. Early observations by Herrick (1895) and Hadley (1912) demorist fated the impor tance of olfact ion food detection Mcleese $(1970,1973$ c) determined the olfactory responses of adult lobsters to various solutions from prey species and iniplicated amino acids as compounds capabie of eliciting food-seàrching behaviour. Ache (1972) and Shepheard (1974) observed that chemoreceptors in the lateral antennular filaments of lobsters respond electrophysiologically to variety of anino acids and that prolonged discharge may be a possible mechanism of peripheral dis crimination of specific amino acids (Ache., 1972).

The stereotyped food-searching behaviour or feeding response of adult iobsters has been described by McLeese (1970) and Atema and Engstrom (1971). Observation of feeding responses has been used to detect the effects of various pollutants on lobster behaviour (McLeese, 1973a; Atema and Steiri, 1974). 
Imature lobsters have never been studied in terms of their: at: traction to and selection "of prey. Studies related to the potential culture of lobsters were concerned with the nutritional requirements and agonistic behaviour of jưvenile lobsters (Castell et al., 1975, 1976; Mason, 1977; Logan and Epifanio, 1978; Zeitlin-Hale and Sastry, 1978). The lobsters used in these studies generalily ranged from fifth to fourteenth stage (less than one year old). Because these young lobsters moult frequently in laboratory situations, their metabolism may be in a constant flux between moult and intermoưlt stageș.: They are not particuilarly suited to olfaction and prey selection experiments which require individuals in a stable intermoult stage

Larger jumbture fobsters (one year old to maturity), which pro bably moult once or twice a year in Newfoundland waters (Templenan 1940), are amenable to laboratory studies. They are space than adult lobsters for holding stock populations and remain in stable intermoult for relatively long periods:

Apart from the practical aspects of working on imature lobsters these animals probably comprise a muerical majority of the natural lobster population, as the adults are susceptible to an intense fishery which may take up to $90 \%$ of the avallable legal-sized lobsters (Squires, f970) Immature 1obsters may have a considerable effect on the biota of the shallow subtidal zone in which they occur. As food is one of the most important ecological factors controlling marine organisms (Miller et al , 1971), the present study is concerred with the attraction to and selection of prey by inmature lobsters.

Because the feeding behaviour of immature lobsters had not been studied before the approach of this study was to look at problems at 
various levels where attraction to and selection of prey may occur, rather than concentrate on one particular aspect. "In the ffinal analysis of prey selection, the results of the various experiments are integrated to describe the nature of feeding in inmature lobsters and several factors which mediate attraction to food and affect the selection of prey.

Specifically, the purpose of this study was to determine the relative attractiveness to imatture lobsters of prey effiuent prey extracts, intact prey, and the chemical components which are characteristic of particular species Selection of prey by immature lobsters was determined in the laboraton and the natura d det of imature placentia Bay was deternned by gut content analysis the results af the various experiments are discussed in tem of the prenises optimal foraging hyotheses (see Pyke et al, 1977 for review) and integrated with the present knowledge of feeding behaviour of adult lobsters and their habitat relationships. 
MATERIALS AND METHODS:

Collection and holding conditions

(1) Innature lobsters were collected from Arnold's Cove, Grassy Point, and Spencer's Cove in Placentia Bay (Figure i) by SCUBA divers licensed by Erivironment Canada All lobsters were obtained from nearshore talus areas in depths of water ranging from 3 to 8 metres. They were transported in colers to the Marine Sciences Research Laboratory at Logy Bay and allowed to acclimate at ambient temperatures before recording of individual wet weight carapace length and sex buring the period November 1975 to December 1976 . 776 individuals were collected (see APPENDIX A) Seventythree lobsters $(1.5 \mathrm{~g}-163.8 \mathrm{~g}$, mean wet weight of $64.4 \mathrm{~g})$ were is kept in the Iaboratory for experimental purposes The remainder $1.3 \mathrm{~g}$ $275.4 \mathrm{~g}$; mean wet weight of $85 . \mathrm{Ig}$ were analysed for gut contents. Lobsters were kept in individuat compartments of a long tank $(490$ cn 75 on $\times 12$ an), the compartments separated by plastic mesh on wooden frames compartments were labelled to allow identification of individuals water at $12^{\circ} \mathrm{C} \div 1^{\circ} \mathrm{C}$ was supplied continuously from an overhead heated reservoir When the long tank was filled to capacity additional lobsters were kept in shallow fibreglass tanks supported by Aframes and continuously supplied with water ambient temperature Shelter for lobsters was provided by seval rocks and a scallop value in each compartment. Natural ight was avalable from three windows on the north side of the laboratory.

Lobsters were fed every week a ration of fresh cod and pork liver equal to $6 \%$ of the individual's wet weight Mclese $(1972 \mathrm{~b})$ observed 


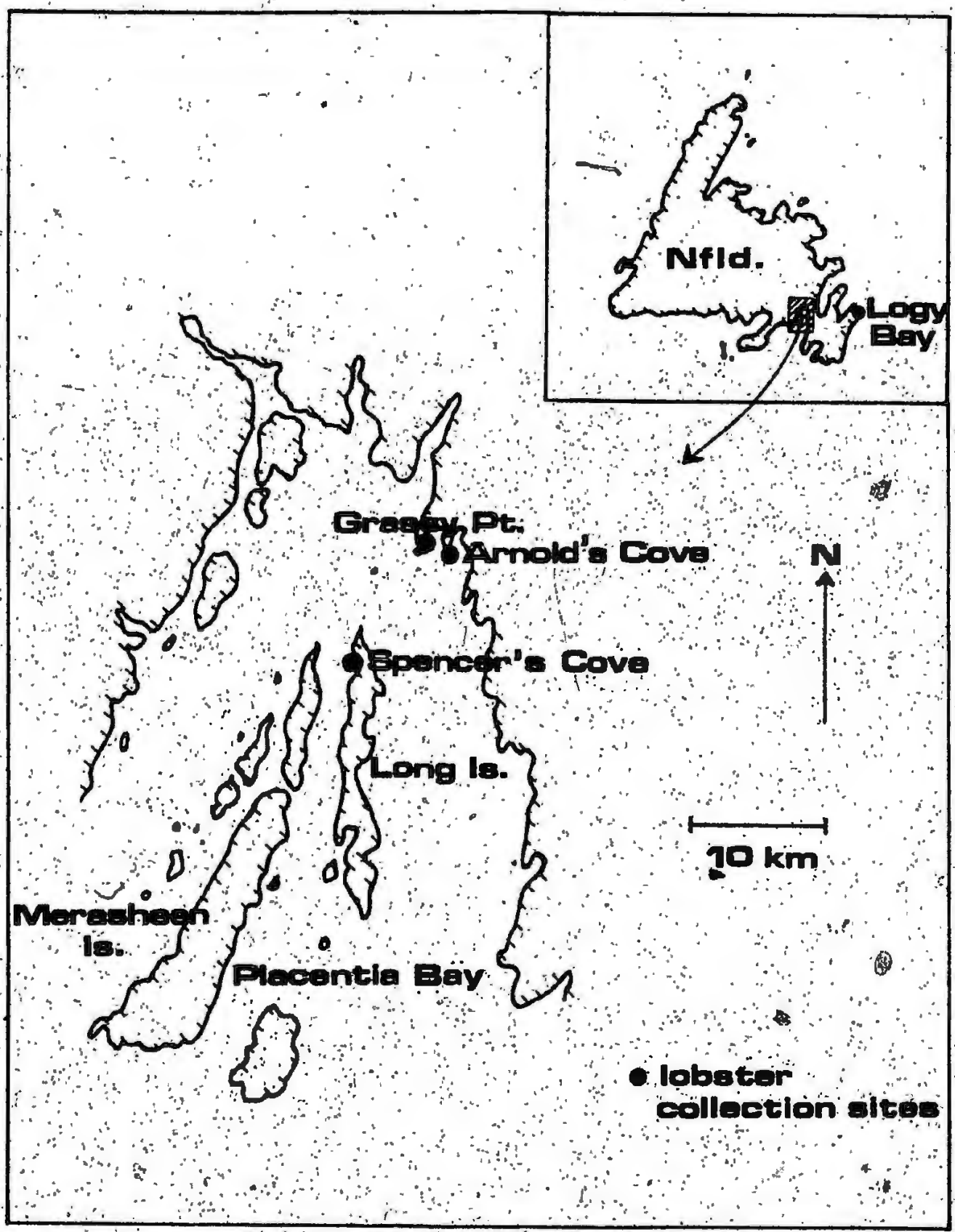

Figure 1 Placentia Bay collection sites of immature iobsters (Hianericanus:) 
that feeding lobsters cod and liver at a rate of $6 \%$ of lobster. weight per week supported heal thy growth. If feeding of lobsters was delayed for any reason; the ration was adjusted accordingly to maintain the $6 \%$ feeding rate. : Lobsters quickly consumed the food. Any excess was removed after two days. The tanks were periodically dráined and cleaned to reduce diatom and algal fouling. The mortality rate of lobsters was approximately 10 throughout the duration of experiments, and was due manly to canniba1ism when a lobster entered another's compartinent.

Prey organisms were required for many of the experiments. They were obtained by SCUBA divers while collecting lobsters and at other times from locations around the Avalon Peninsula All prey organisms were main tained together at amblent temperature in shallow fibreglass tanks supplied with sand, rocks, and scallop valves Densities were carefully maintained to prevent starvation of individuals

Attraction to prey extracts

$A$ woden trough coated with epoxy resin-(Figure 2); built approximately to the specifications of Mcleese (1970), was used for all trials involving attraction of lobsters to prey extracts o The trough was 1,5 long by $0.9 \mathrm{~m}$ wide with a water depth of $0.1 \mathrm{~m}$. Water from the heated reservolr $\left(12^{\circ}\right.$ C. $\pm 1^{\circ}$ C) was supplied to the upstream well at a rate of 3.3 .1 per minute. Dye tests indicated a current velocity of approximately 15 cm per minute frop the upstrean to the downstream baffle.

The floor of the trough was marked off into grid of squares 10 cr by $10 \mathrm{~cm}$ to accomnodate tracking of lobsters in the trough. A semicylinder of polyviny lchloride approximately 12 cm wide by $8 \mathrm{~cm}$ high was placed at right angles to the downstream baffie, in the mid-ine of the $1 \div$ trough This sheiter for the lobster was capable of telescoping such that 


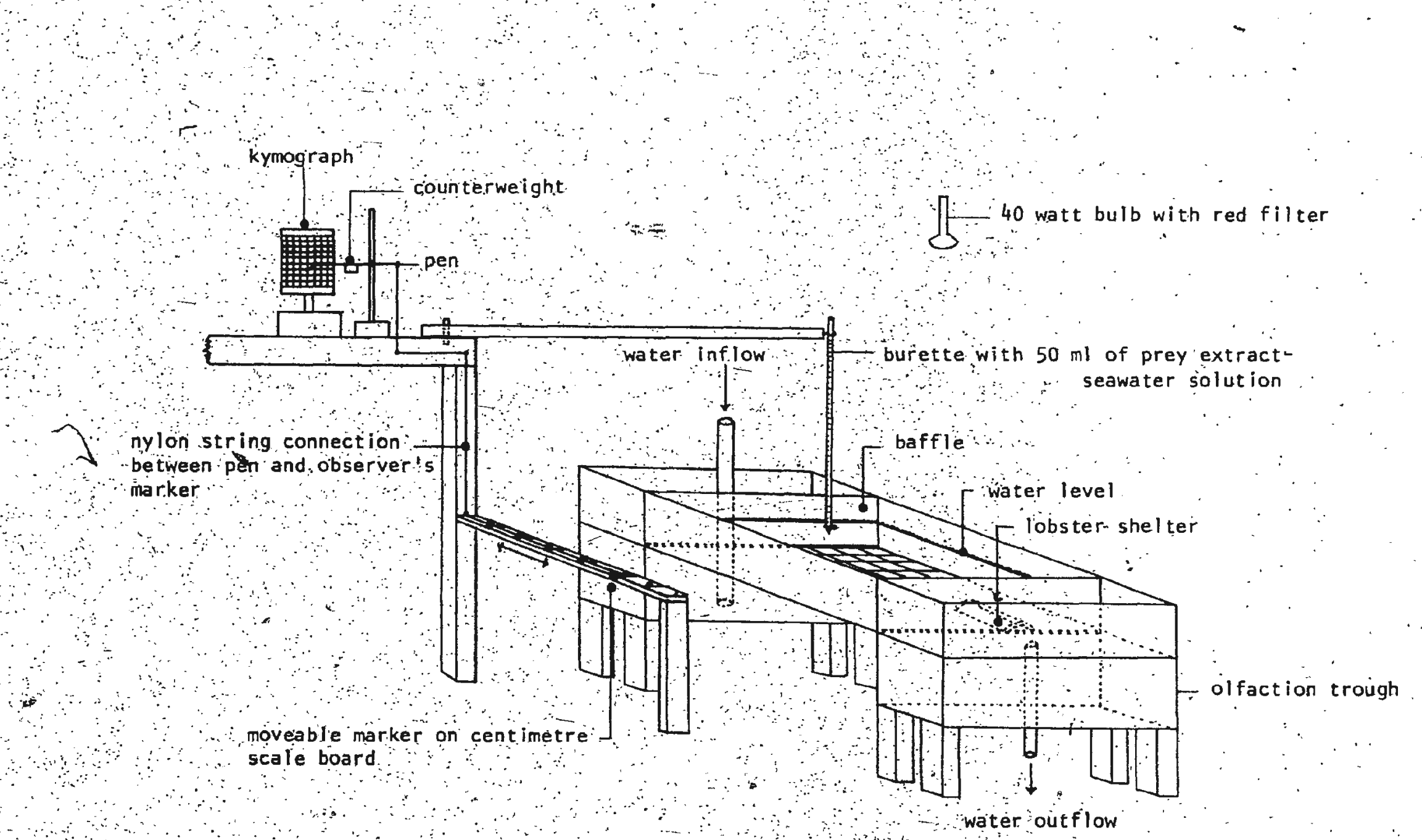

Figure 2 Schematic diagram (not to scale) of offaction apparatus used to observe attraction of immature lobsters (H. americanus) to prey extracts 
the length of the semi-cylinder was twice the total length (excluding antennat) of the lobster.

The extract was applied to the -trough from a burette hanging

n-a approxinately 2 cm over the water surface at a distance of 70 on from the proxiderend of the lobster shelter. The burette was supported by a swinging rod which allowed maintenance of a $70 \mathrm{~cm}$ distance when the sheitèr lëngth was changed.

Near the olfaction trough was a board $(2 \mathrm{~cm} \quad 2$ an) secured to a tank frame The board was scored with a scale marked at intervals of 2 cm each 2 cm interval corresponding to $10 \mathrm{~cm}$ on the floor of the trough A wooden marker fitted to the scale board was attached by nylon $\$$ tring through several eyescrews to a counterweighted kymograph pen (Figure 2) The kymograph was fitted with lined graph paper, Movement of the pen was calibrated such that a $2 \mathrm{~cm}$ movement of the marker would cause a pen deflection of $1 \mathrm{~cm}$ (j.e.? I ch on the graph paper equaled $10 \mathrm{~cm}$ on the floor of the trough):

Movements of a lobster in the trough relative to the opening of the shel ter were recorded by the observer by moving the marker on the scale board The rostrum was the point of reference on the Iobster This produced a simultaneous recording (minus a very small lag due to observer reaction time) on the kmograph. The kymograph speed aliowed 20 minute trials. The apparatus pernitted simple efficient recording of duration of lobster response and the number and lengths of exits from the sheiter:

Prey extract - seawater solutions were prepared from healthy, well-fed prey organismg before each set of trials Individuals of a size range naturally acceptable to jobsters were dried thoroughly with 
10.

paper towels and crushed with a jortar and pestle into a reasonabiy uniform mixture of body flüids, tissue and hard parts. The mixture was strained through a fine $(1$ mon) nylon mesh. The resultant prèy extract: was diluted to $10 \%$ by volume of a prey extract seawater solution Fifty inl of the 10s prey extract seáwater solution were applied by burette in each trial The densities (weight per, unit volume) of the prey extracts were determined on a Metererectronic balance, and dif fered by no more than \pm . 5 the water content of prey tissues was de temined drying on dozen each of cancer, Mytilus Strongyocentrotus and Asterias to a stabie weight in an oven at $100^{\circ} \mathrm{C}$ The mean water contents of tissues rarged from approximately 55 for pht lus with sheil to approximately 708 for Cancer and the echinoderms.

Lobsters from the 1aboratory stock population after generally more than four days of food deprivation were tested in the olfaction trough for attraction to prey extract seawater solutions of Asterias vulgaris, Gancer irroratus jytilus edulis, Strongylocentrotus droebach iensis and seawater control lobsters were allowed to acclimate to the" trough and settle into the shelter for one hour at which time the extract was introduced to the trough and the kymograph turned on simutaneoùisiy:

The observer tracked the lobster for 20 minutes with movenents of the scale board marker Exits from the shelter were described as exploratory or food-searching behayiour and noted as such paper pang with the time Food-searching behaviour was recorded if the iobster showed vigorous motions of the maxilipeds pereiopod scopping and lunging as it moved towards the stimus source These behaviourai patternst have been clearly associated with food-searching McLeese, 1970 Atema 
and Engstrom, 1971) Ary locomotion of the lobster while not showing the above behaviour was classified as exploratory.

Prel iminary trials indicated severe inhibition of lobster behaviour outside the shelter during daylight Aluminu foil shields over the eyes of lobsters were tried (Mcleese, 1970) Initial observations suggested that the hhields caused errat ic behaviour Consequently, studies of attraction of imature lobsters to prey extracts and all subsequent exper iments were conducted at night. The onily artificial light source was a 40-watt bilb covered by a Kodak l-A red filter hanging over the trough Kennedy and Brumo (1961) noted that lobster vision is ineffective in the red wavelengths. With this arrangement, Iobsters moved freesiy about the trough and apparently not disturbed by movements of the observer One or two lobsters were run in the trough each night Each lobster was sub jected to two or three extracts in randon sequence, with forty minutes be tween each trial to allow the trough to flush adequately.

No lobsters were tested during their moulting periods or during the post-moult period when the natural diet appears to be calcium-rich (Weiss, 1970) Mytilus, Strongylocentrotus, ard the seawater control were tested before the first moulting period of lousters in the laboratory Asterias and Cancer were tested with the same lobsters several months after the lobster moulting period, when these prey, were more easily collected in the natural environient. In this case, the period of foprivation of individual lobsters was the same as in the first set of trials plus or minus one day. Ten other lobsters fed natural diets of Cancer Mytilus, and Strongylocentrotus were tested in the fall of 1976 In all twentynine lobsters (18 females and 11 males) of mean wet weight $51.8 \mathrm{~g}$ were tested, although not all lobsters were subjected to all prey extracts 
Several preliminary experiments indicated that individual variation. in response was much' smaller than population variation. The results were therefore analysed for significant differences by a paired comparison randomised block design, eliminating the effect on calculations of variance due to inherent population differences (Sokal and Rohlf, 1969) :

Five response variabies were analysed. These were: total duration of food-searching responses per trial; number of exits with foodsearching behaviour per,trial; mean maximulength of food-searching exits per trial; total duration of exploratory 'responses per trial;' and integral of the food-searching response curve (determined with a Hruden planimeter by tracing the line of the curves (see Figure 3)). The last variable: was a function of all other food-searching variabies and gave an overall measure of lobster attraction to prey extracts.

'Attraction to prey effluents

Individuals of Cancer, Mytilus, and Strongylocentrotus were maintained without food for 24 hours in tanks at $12^{\circ} \mathrm{C}$. with $20 \mathrm{ml}$ of seawater per gram of organism wet weight to collect effluent with metabolites. Aill individuals had been well-fed and were of a size range naturally acceptable to immature lobsters... Individuals were carefully checked for injuries which might bias the amounts of metabolites in the seawater. At the end of the collection period the organisms were removed, the tank water was stirred and $100 \mathrm{ml}$ of effluent for each trial were filtered to remove faeces : $r$

Lobsters from the laborat ory stock populat ion, deprived of faod for five days, were placed in fibreglass tanks with 1.51 of sea- 


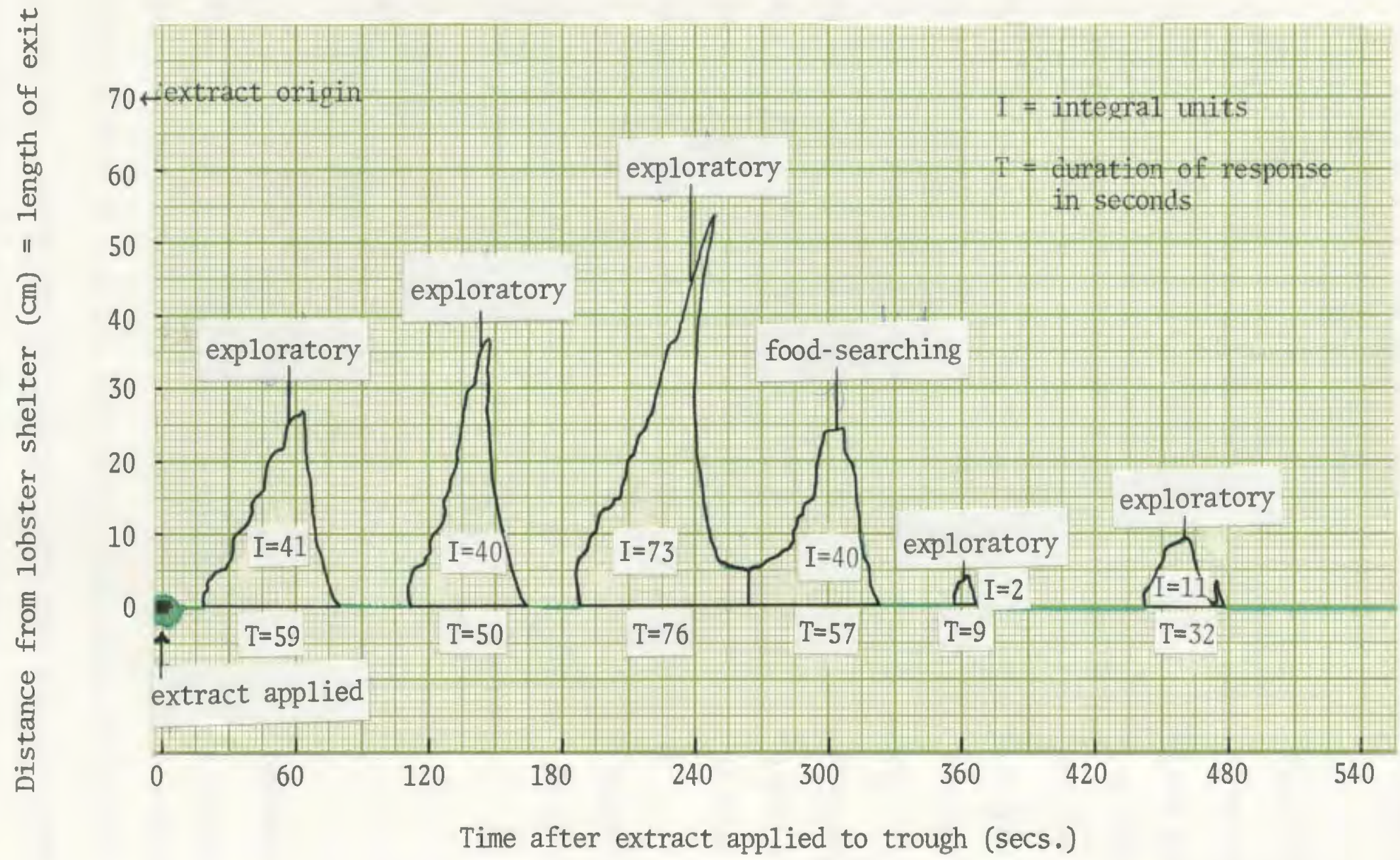

Figure 3. Portion of kymograph record of an inmature lobster (H. americanus) responding to extract of Asterias. 
water at $12^{\circ} \mathrm{C}$. They were allowed to acclimate to the tanks for one hour. No shelter was provided.

A checklist of fifteen behaviour types (see Table 6, p. 33) which could possibly be elicited by prey effluents was made, based on previous observations and those of Atema and Engstrom (1971). One lobster was tested at a time. Prey effluent was poured very gently into the distal part of the tank, away from the corner in which the lobster had settled. Controls consisting only of seawater were applied in the same way. Behaviour types were checked off on the list as observed. At the end of five minutes the tank was drained, thoroughly rinsed and refilled with seawater: "The lobster.was allowed to settle for one hour before being tested again. other lobsters were tested in the interim. prey ef-? fluents were applied in random sequence. All tests were conducted at night.

Percentage frequencies of occurrence of behaviour types elicited by 'the prey effluents were tested for significant differences.by G-teșts of heterogeneity (Sokal and Rohlf, 1969).

Attraction to ninhydrịn-positive compounds (NPCs)

The following amino acids and related compounds were obtained from Sigma Chemicals Limited, St. Loüis, Missouri, U.S.A.: DL-alanine, L-arginine, L-asparagine, DL-aspartic acid, DL-glutamic acid, L-glutamine, glyçine HC1, DL-leucine, DL-lysine; L-proline, DL-serine, taurine, and DL-valine. Ammonium chloride.was obtained from the chemical stores of the Memorial University Biology Department.

Lobsters from the laboratory stock popiulation, deprived of food 
for five days, were placed in shallow fibreglass tanks $(40 \mathrm{~cm} \times 30 \mathrm{~cm} \times$ $10 \mathrm{~cm}$ ) containing 51 of seawater at $12^{\circ} \mathrm{C}$. and allowed to acclimate for one hour. Each tank was numbered for identification of individual lobsters. Five or six lobsters. were tested simultaneously in a single night.

Solutions of NPCs were prepared immediately prior. to testing. The required amounts of crystals were weighed on an Dertling electronic balance. Crystals were poured into a $14.2 \mathrm{ml}$ glass vial and $10 \mathrm{ml}$ of distilled water ddded to produce a $1 \times 10^{-1} \mathrm{M}$ solution. Whatman \#5 filter paper was rolled into a plug and placed in the vial to close the opening and act as a wick for the solution. One NPC target was prepared for each lobster. For DL amirio acids, double the required amount of crystals was added to the vial to produce $1 \times 10^{-1} \mathrm{M}$ solutions of the $\mathrm{L}$ ster:eoisomers.' D stereoisomers do not appear to be stimulatory to decapod crustaceans (Mackie; 1.973). Aspartic acid, glutamic acid, and leucine were not totally dissolved. Vials containing the last. three amino acids were stirred vigorously to produce a uniform mixture to accelerate dissolution in the test tanks. Solutions were not buffered as the minimm terminal concentration in the test tanks was presumed to be too low to cause $\mathrm{p} H$ changes.. Changes of $\mathrm{pH}$ between 5 and 8 do not affect lobster. response (Levandowsky and Hodgson, 1965).

Rubber gloves were worn throughout the preparation and application of the NPC targets as handsweat is potentially stimulatory to "Invertebrates (Zafiriou, 1972): NPC targets were gently placed in the corner of the tank opposite to that in which the lobster had settled. The possible minimum terminal NPC concentration in the tanks was $2 \times 10^{-4} \mathrm{M}$ Lobsters were observed for ten mimites." The time to seizure 
of the target was noted. Seizure was defined as grasping of the target with the maxilipeds. At the end of the trial the tanks were drained, rinsed and refilled with seawater. The-lobsters were allowed to rest for a half hour before the next trial. A11 lobsters were eventually subjected to all NPCs and a seawațer contro1. The şequence of testing was randomised eachi night.

Differences between percentage frequencies of NPC tárget seizure and control target seizure were tested for significance by 'Cóchran's Q-test (Sokai and Rohif, 1969).

Analysi of NPCs in prey.tissue extracts and effluents

Prey tissue extracts were collected from Asterias viligaris, Cancer irroratus; Littorina, littorea, Mytilus edulis, Nereis sp, , Ophio: pholis aculeata, and Stronglocentrotus droebachiensis using methods described previously. Only healthy, well-fed individuals of a size susceptíble to immature lobster predation were used. "With Littorina; Nereis, and Ophiopholis, eight individuals of each genus were pooled to produce one sample of tissue extract.

Tissue extracts were centrifuged $\left(6500 \mathrm{~g}, 4^{\circ} \mathrm{C}, 60\right.$ minutes $)$

to remove particulate matter. For each sample; a 0.5 m1 aliquot of super natant was deproteinised by adding $30 \mathrm{ing}$ of sulphosalicylic acid, and centrifugation" ( $6500 \mathrm{~g} ; 4^{0} \mathrm{C} ., 20$ minutes). The volume of the supernat- ant was adjusted to $2.0 \mathrm{ml}$ using a $0.2 \mathrm{M}$ sodium citrate buffer (pH 2.2), then analysed with a Beckman Spinco automatic amino acid analyser (Model 121) equipped for physiological analysis: polyamine analyses were made in a similar manner except that a colum containing Beckman polystyrene 


$$
\text { - } 2 .
$$

17.

resin (Beckman PA-35) and two eluting concentrations of sodium citrate buffer (0.35 and $2.35 \mathrm{M}$ sodium, $\mathrm{pH}$ 5.2) were used.

Prey effluent was collected by allowing individuals to remain in separate tanks with $7 \mathrm{ml}$ of seawater per gram wet weight of individual for eight hours at $12^{\circ} \mathrm{C}$. The prey were removed and the, seawater - prey effluent stirred vigorously: Five 'ml' aliquots were collected and analysed by the procedure described above Seawater controls were also analysed. Significant differences between Individual NPC concentrations of each prey were determined by confidence interval analysis Natrelia, $1972)$

Controlled preyt selection

Prey selection by imature lobsters was óbserved by placing. one each of various prey species (Asterias vulgaris Cancer irroratus, Harmothoe sp., Littorina littorea, Mytilus edulis, Nereis sp Ophiopholis aculeata and Strongylocentrotus droebachiensis) in fibreglas tanks with approximately 31 of seawater at $8^{0} \mathrm{C}$. Prey were weighed before being placed in the tank. A rock and a scallop valve furmished shelter for the prey organisms. Air was supplied via an airstone to each tank was added an immature lobster deprived of food for five days: The tanks were left undisturbed for 24 hours at wich time observations were made.

Combinations of prey were arranged such that lobsters had a choice of at least four species Nereis sp. and Harmothoe sp. were never offered simutaneousiy on the few occasions when Cancer was offered similtaneously with a polychaete or ophiopholis, the Cancer individuals were presumed to be too small to inflict damage on the other prey species. 
In combinations with Asterias, no predation by Asterias was observed:

In any case, to minimise prey interaction, all individuals were weld fed and presumably satiated. To prevent escape of prey, the water level was never beyond the reach of the claws of the lobstens. Approxinately 20 lobsters were used in these experiments with repilication of three or four trials per lobster. Prey organisms were of a size thought to be susceptible to predation by the lobster in each tank. They were collected at random from various Iocations in Placentia Bay and around the Avalon Penjusula and to some extent reflected sizes naturaliy available to lobster populations.

Percentage frequencies of attack of each prey were noted for afi trials Attack was defined as any visible injury to prey The amount of individual prey presumably consumed wa recorded by subtracting the weight of the remans from the original wet weight of the organism. Significant differences between percentage frequencies of attack were determined by G-tests of independence (sokal and Rohlf, 1969).: Differences between consumption rates and consumption efficiencies for each prey were analysed by Student-Newman Keuls multiple comparison tests (Sokal and Rohlf, 1969) Confidence interval analysis (Natreila, 1972) was used. to determine effects of prey size on attack rates.

Gut content analysis

Between June 4 and November $25,1976,103$ immature lobsters were coliected by SCUBA divers from three placentia bay collection sites (Figure $1, \mathrm{p}, 6$ ) Lobsters were collected in the morning to reduce the influence of digestion on gut contents from feeding the night before 
collection. They were transported to the laboratory in coolers with freezer packs." In the laboratory, "lobsters were weighed, measured, sex. was determined, and two pleopods were clipped for moult stage determination (Aiken, 1973).

Lobsters were killed by severing the body behind the carapace. The thorax with gut intact was stored in $70 \%$ alcohol for later analysis. Guts were excised by dissection. The oesophagus was cut midway between the mouth and the cardiac stomach and the intestine cut immediately beHind the pyloric stomach Gastroliths were scraped off the gut walls if necessary Wet weight of gut and contents was determined on a Mettler electronic balance Gut fullness was visual estimated according to a scale of 0 to 4 (empty to fuil) The gut was then cut open and the contents flushed into a Petri dish. Wet weight of the empty gut was deter "mined after it had teen patted with a paper towel.

The gut contents were flooded with distilled water and observed. under a dissecting microscope at $20 x$ mantication As mach as possible, all particles were identified and pushed to the periphery of the dish. The dominant species was recorded based on a visual estimate of relative volume The percentage contribution of individual taxa to the total tolume of gut contents was estimated in each case A11 samples were observed twice to minimise errors of omission. The distilled water was drained and the contents allowed to dry by evaporation Dry weight of contents was deternitined on the Mettler balance Dry volume was determined by pouring the contents into a 10 mi cylinder and shaking vigorously to allow even settlement of the contents

Identification of prey hard parts was confirmed by reference to various texts of invertebrate zoology and previous studies of lob- 
20.

ster gut contents (Miner, 1950; Weiss, 1970; Megitsch, 1972). : To assist in identification of harf parts, many invertebrate species were dried, broken apart, and examined under a dissecting microscope prior to gut content analysis.

To determine the residency in the lobster gut of hard parts from natural prey consumed" prior to capture, several immature lobsters were maintained in the laboratory on a diet of cod and pork liver, both of which leave no visible parts in the gut After various periods (two to 180 days , the contents of guts of these lobsters were exanined.

To estimate rate of clearance of gut contents, 14 lobsters were maintained at 8 o $C$ and fed libitum diets of either Cancer ir roratus, Mytitus edulis, or Strongylocentrotus drobachiensis. After periods ranging from one to eight days, the gut contents were observed and various measures of stomach fuliness recorded.

Significant differences between percentage frequencies of oc currence of gut items in sumer, late summer, tand fall were detcermined by G-tests of independence (Solcal and Roh1f, 1969). The various measures of gut fulliness were analysed by Model itanalysis of variance (Sokal and Rohif, 1969 .

Prey density in Placentia Bay

During the period of collection of lobsters for gut content ana1ysis, prey density was observed in Arrold's Cove, Grassy Point, and Spencer! s cove (Figure $1, \mathrm{p}: 6$ ) A square metre quadrat wás dropped at random to the bottom $(3-8 \mathrm{~m}$ depths $)$ in the collection areas by a SCUBA diver Al1 organisms which were readily visible to the diver 'not under 
rocks) were counted. Approximately eight. quadrats were completed in each of the three-locations. As there were very few differences in prey densi-" ties between the three collection areas, the results were pooled to provide a mean organism density in the collection areas in late summer and fall. 
RESULTS

\section{1}

Attraction to prey extracts

There were two general types of behaviour elicited by stimuli in the olfaction trough. The first; exploratory behaviour, was shown by al1 lobsters regardless of the quality of the stimulus. This behaviour was characterised by quick, nondirectional walking on the pereiopod tips with the antennae held in front of the lobster at an angle of approxinate1y $120^{\circ}$ to one another: Quite often the antennae were rubbed against the trough floor and walls (Foure 4a). During exploratory forays the flocking rate of antennules was reiatively constant occasional movement of the third maxillipeds was observed Scaphognathite fanning rate was rel atively constant.

Exploratory behaviour was especially commor within a half hour of a lobster being placed in the trough. Repeated observations indicated that this behaviour diminished considerably after a half hour. By this time lobsters generaliy had settled into the shelter and rarely left except when a stimulus was introduced to the trough. After one hour in the trough, lobsters were able to find and enter the shelter after exploratory forays, regardiess of the light conditions.

Food-searching behaviour, elicited by all prey extracts to some extent, was quite distinct from exploratory behaviour. Once the lobster had detected the stimulus, the antennae were usually directed in front of the lobster, at an angle of less than approximately $40^{\circ}$ to one another The lobster assumed a position close to the trough floor and scooping of the first and second pereiopods was obvious (Figure 4b) "The third max- 


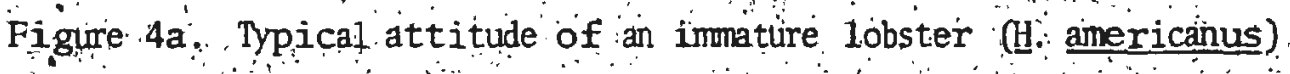
during an exploratory foray $(x, 1)$

Figure 4b. Typical attitude of an immature lobster (H americanis) showing food-searching behaviour $(x)$ Note that the antennae are not drawn together because of the resistance of the tank wall pereiopods and claws are drawn into the mouth region 
24.

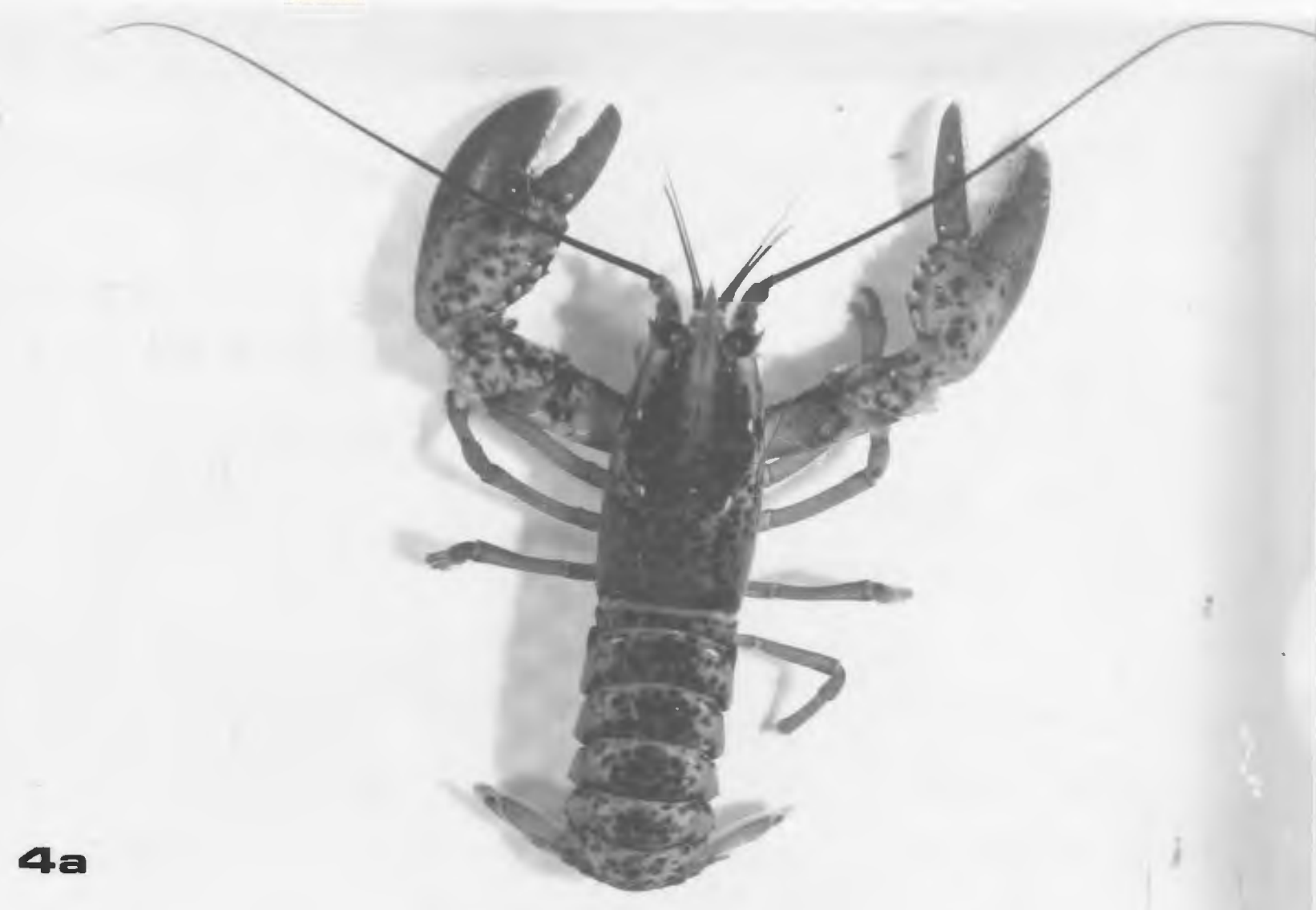

$4 b$ 
illipeds were frequently folded into the mouthregion, ficking rate of antennules and fanning rate of scaphognathites were accelerated. The 1obster proceeded towards the stimulus origin with very sudden forward movements and occasional lunges at the stimulus. This was in contrast to the fluid motion of lobsters during exploratory forays on a few occasions the claws were raised and sometimes opened

Al1 prey extracts, except that of Asterias; were attractive to inmature lobsters' in terms of food-searching response relative to the control Results are recorded in Table 1 . Falues of the paired comparison tests are noted in Table 2 . Extracts of Cancer el icit the greatest attraction from inma ture lobsters, the mean integral of food-searching response curves being more than twice as great as that for Nytilus ext ract trials : Asterias and Strongylocentrotus extracts were relatively uriattractive. Seawater controls elicited few food-searching responses Differences between Cancer integrals and those for Asterjas and Strongylocentrotus were very significant (Table 2) The difference between the Mytilus integral and that for Strongylocentrotus was significant. Integrai values for al 1 prey extracts, withe the exception of Asterias, were highly significantly different from the control integrals.

The other three food-searching response variabies (Table 1) showed similar trend, with the cancer values highest Mytilus values sontewhat iower, and the values for the echinoderm species generally-iowest. For most of these variables, differences between Cancer values and others were significant values, for the control were significantly lower than those for all prey extracts excluding Asterias:

Durations - of exploratory responses were greatest in the control trials (Table 1) although only the difference between the control 


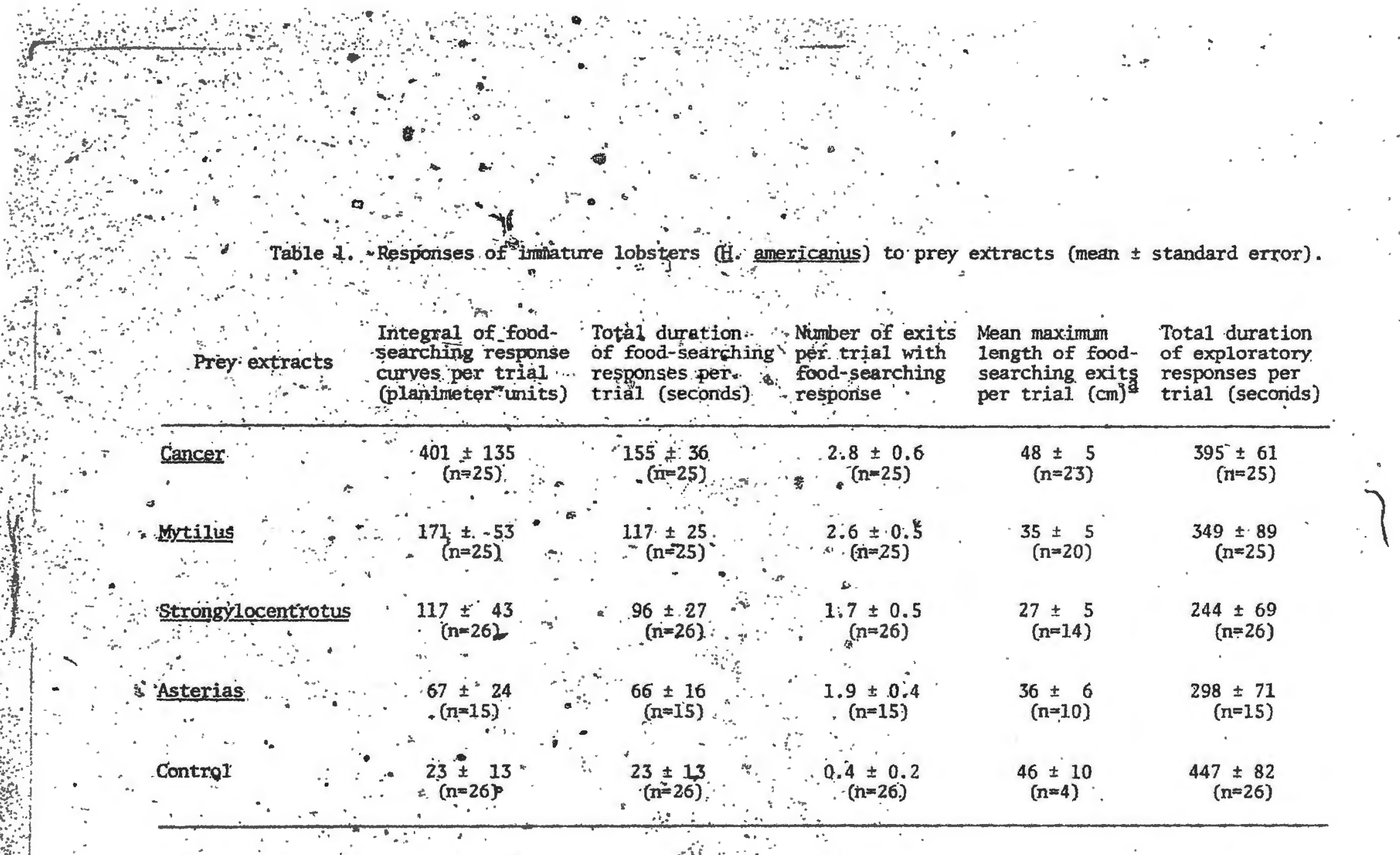

a based only on trials in which food-searching responses. were detected 
Table 2. "Paired comparison F values for responses of imature lobsters (ㅍ.

Prey extraçt! - Integral of food-

Paired comparison searching response of food-searching

P. searching response of food-searching curves responses

Number of exits Mean maximum $\therefore$ Total duration with foodlength of food- of exploratory ..... Sponse

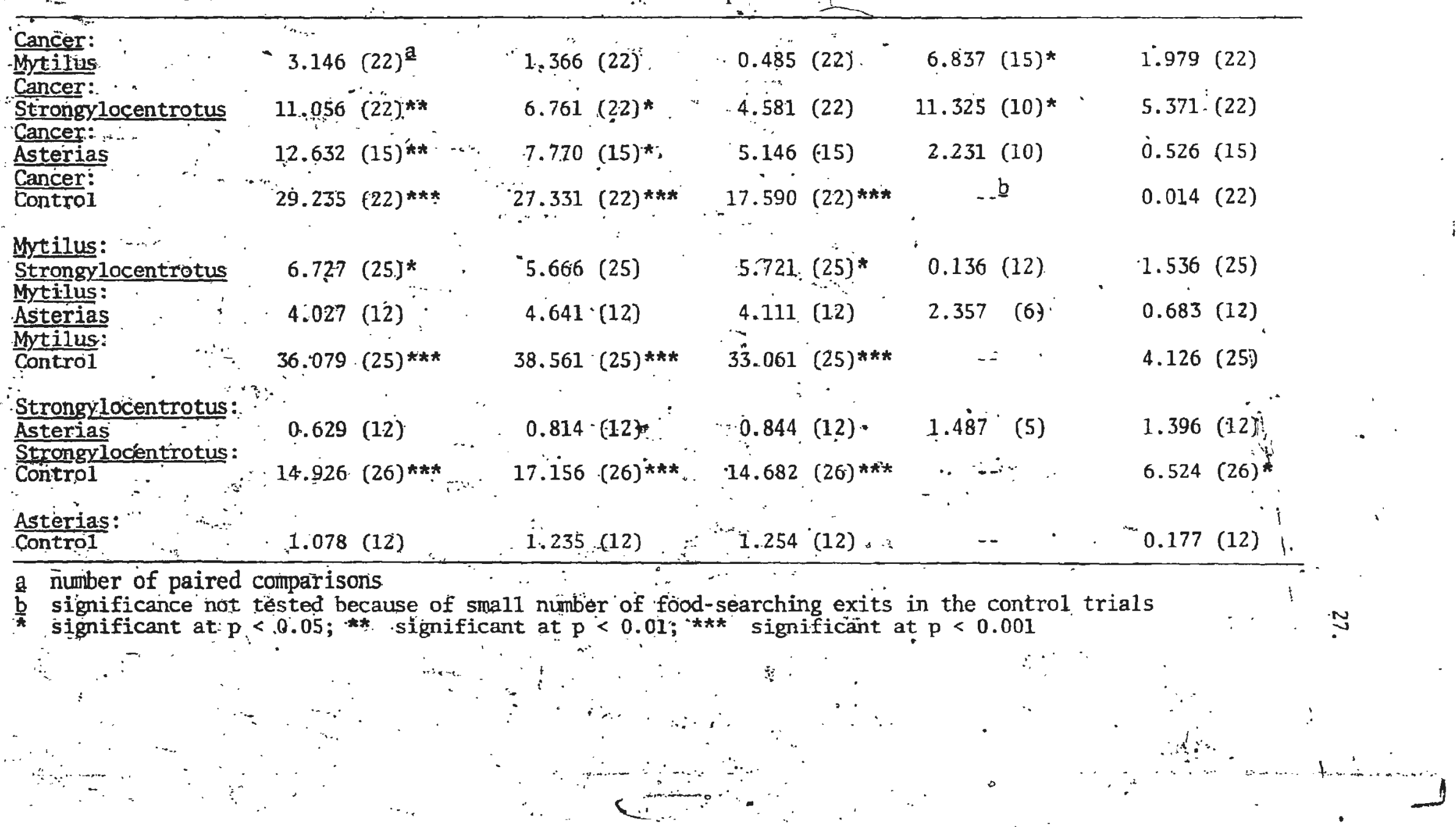


28.

and Strongylocentrotus values was significant. The Cancer value was slightly greater than the Mytilus value. The latter was greater than either of the two echinoderm values.

The percentages of trials in which food-searching responses were elicited by the stimulus are noted in Table 3. The percentage was highest for Cancer, followed by Mytilus and the two echinoderm species. Very few trials with seawater control elicited a food-searching response in lobsters. Significant differences determined by STP G-tests are noted in Table 3.

The percentages of immature lobsters showing food-searching behaviour. at the stimulus origin (70 cm from the lobster shelter) are noted in Table 4. Cancer extract elicited the highest percentage, followed by Mytilus, Asterias, and Strongylocentrotus. Onily two lobsters showed food-searching behaviour at the stimulus origin during seawater control trials. Only the Cancer value was significantly greater than the control vaiue,

An indication of preference was determined by comparing the integrals of food-searching responses for 22 inmature lobsters, each of which had been subjected to extracts of Cancer, Mytilus; Strongylocentrotus, and a seawater control. There were too few trials with Asterias extract to allow comparison. The indication of preference was based on the assumption that, in" nature, the greater length and duration "of foodsearching exits reflect greater motivation to attack and consume prey: The comparison (Table 5) indicates a significant preference for Cancer extract over, other extracts, two-thirds, of the lobsters showing greater integral values for Cancer' extract than for other extracts. Only one- : fifth of the lobsters preferred Mytilus extract over others. Strong- 
Table 3. Percentage of immature lobsters ( . americanus) exhibiting food-searching response to prey extracts.

Prey extract

Percentage

Total number of trials

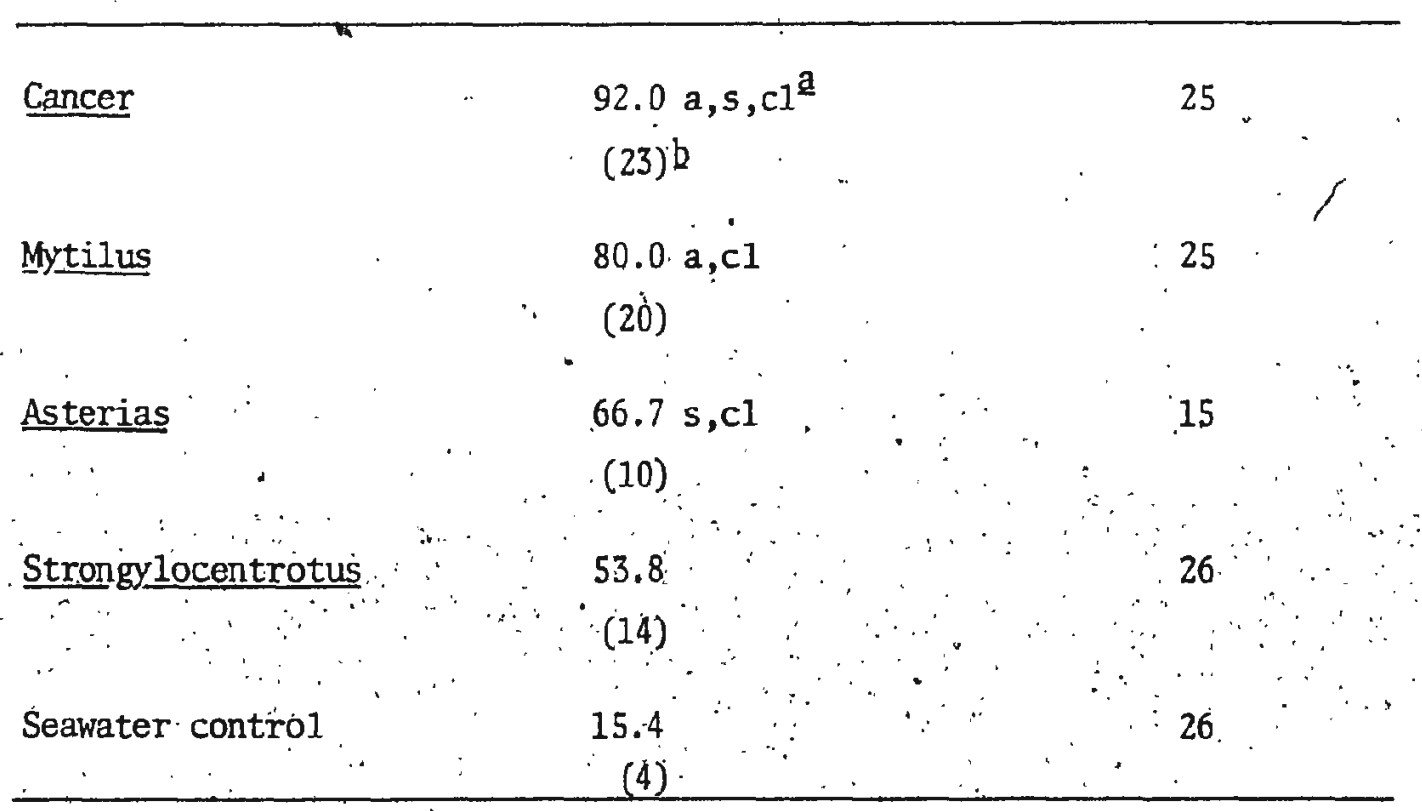

a significantly greater than:
a - Asterias
s - Strongylocentrotus
cl: - control

b absolute number of lobsters responding

$p<0.05$ 
30.

Table 4. Percentage of immature 1obsters (H. americanus.) moving to and exhibiting food-searching response at the stimulus origin.

Prey extract

Percentage.

Total number of trials

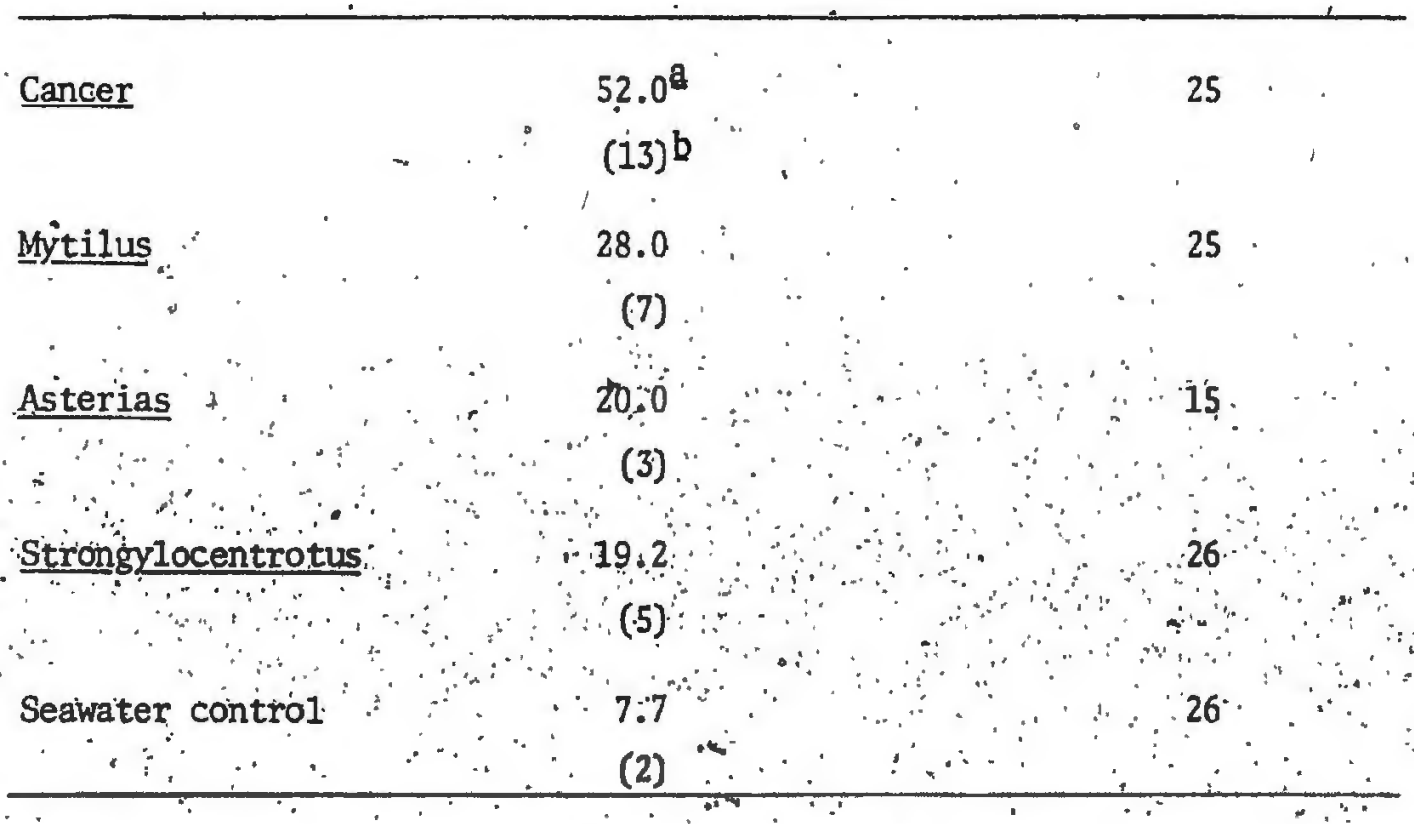

à significantiy greater thạ control, $\mathrm{p}<0.05$

b absolute number of lobsters responding at the stimulus origin 
31.

Table 5. Percentage of inmature lobsters (ㅂ. americanus) in which prey extracts elicited the greatest food-searching résponse (integral of food-searching response curves, $n=\dot{2} 2)$.

Prey extract

Percentage

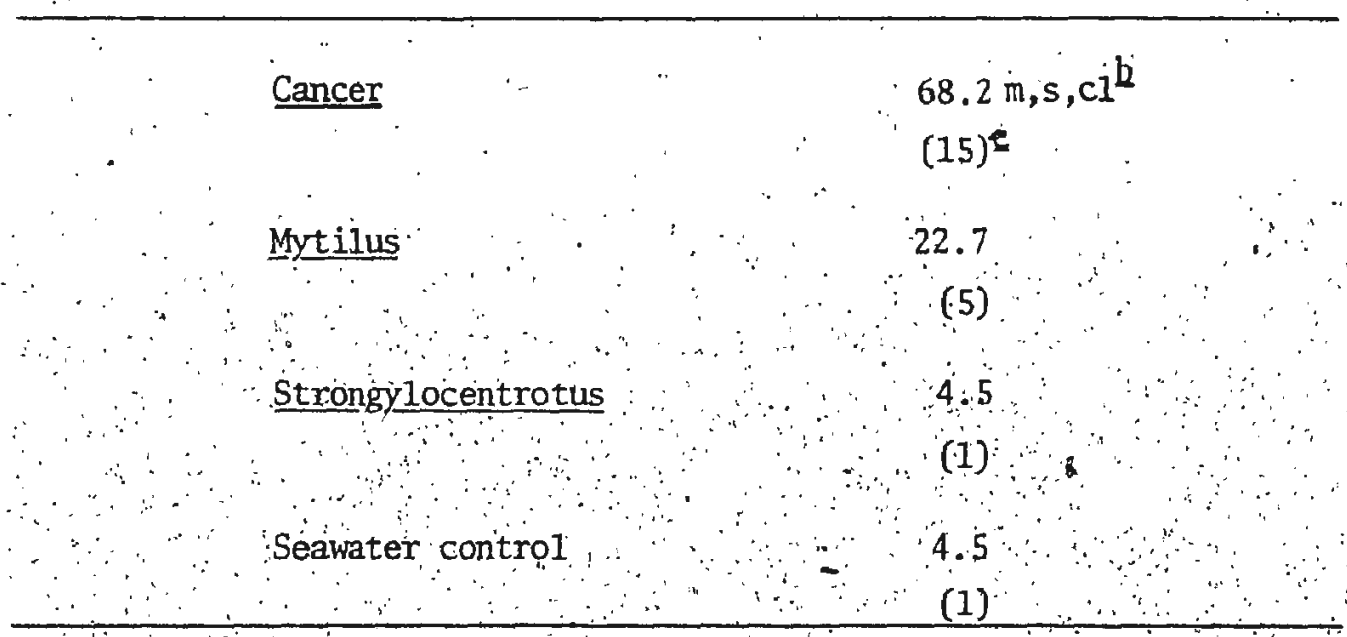

a each lobster was offered all extracts in random sequence; Asterias extract was excluded from the table because of small sample size.

b signifiçantly greater than: - m - Mytilus $\mathrm{p}<0.05$

$$
\text { si - } \frac{\text { Strongylocentrótus }}{\text { control }}
$$

c absolute number of lobsters showing greatest responise to specific prey extract 
ylocentrotus extract was rarely preferred.

Attraction to prey effIuents

At least fifteen behaviour types were observed in imiture lobsters subjected to effluents of various prey species (Table 6): These are noted below with a brief description of each.

Increased antennule flicking rate was observed in most lobsters immediately upon entry of the stimilus. Percentage frequency of occurrence of this behaviour was highest for control trials and lowest for trials with Strongylocentrotus effluent (Table 6) Percentage frequenciess of occurrence of anchor ing and raking of pereiopods, movements which tended to kep the lobster in the tank comer, were approxinately equal for trials with prey effluents and greater for trials with controls. There was little difference between effluents in percentage frequencies of occurrence of directional antennile movement This behaviour was characterised" as a dipping of the antennules towards the source of the stimaIus and was frequently observed inmediately after the stimulus had been applied to the tank.

For behaviour. such as wiping of antennules and artennae with the mouthparts, walking approach to the stimulus source, flexing of maxillipeds, and raising of the body, percentage frequencies of occurrence for control trials were generally substantially lower than for trials with prey effiuents.

Severa1 behaviour types were not observed during control trials. These were directionai movement of antennae (i e pointing towards stimufus source), rapid linging approach to the stimulus source retreat,

$\because$ 
Table 6 . Percentage of inmature lobsters (H. americanus) showing types of behaviour elicited by prey effluents.

Behaviour types

$\because \therefore \quad \therefore \quad \therefore \quad \therefore \quad$ Cancer

alert phase-behaviour

increased antenuilè flicking rate raking of pereiopods

wiping of iantènules and antennae

directional movement of artennae

directional movement of antenuiles

food-searching behaviour

flexing of maxilipeds

scooping of pereiopods

walking approach

rapid lunging approach

snapping and seizing with claws

miscellaneous behaviour

anchoting of pereiopods

body raised

clawis raised

active timning

retreat
53.3

40.0

30.0

26.7 .

20.0

$46: 7^{\star}$

$26.7^{\star}$

$43.3^{\star}$

$13.3^{*}$

$23.3^{*}$

43.3

23. 3 .

13.3

6.7

23: $3^{*}$

\section{$\therefore$ Prey effiuent's}

Mytilus . $\therefore$ Strongylocentrotus

$(n=30)$

30.0

36.7

30.0

20.0

23.3

10.0

36.7

40.0

13.3

40.0

16.7

3.3

6.7

3.3

53.3

13.3

53.3

16.7

$6 \times 7$

3.3

3.3

i0.0
Seawater control $(n=15)$

60.0

60.0

13.3

0

13.3

6.7

0

13.3

0

0

80.0

6.7

0

a.

0 
active turning (constant changing of position in the tank corner), scooping of pereiopods in the mouth region, raising of claws, and snapping and seizing with claws. With the exception of active turning, percentage frequencies of occurrence of these behaviour types were highest for Cancer effluent trials. There were smali differences between trials with Strongylocentrotus and Mytilus effluent in percentage frequencies of occurrence of behaviour types.

For trials with Cancer and Mytilus effiuents, percentage frequencies of occurrence of scooping of pereiopods, a behaviour type characteristic of food searching, were significantly greater than for control trials.

Walking approach, rapid lunging approach, retreat, flexing of maxillipeds, and shapping and seizing wh the claws were all significantly more frequent in trials with Cancer effluent compared to controls.: 6.

Attraction to ninhydrin-positive compounds (NPCs)

Percentage frequencies of response (target capture) of imnature lobsters to various NPCs are noted in Table 7. Proline was the most attractive NPC, followed by anmonia, arginine, lysine, alanine, glycine, and yaline, ail of which produced percentage frequencies of response significantly greater than seawater controls: Al1 other NPCs were attractive to a lesser degree seawater controls el icited responses in $13 \%$ of the triats.

Almost all responses to NPCs were charaçterised by directed movenent to the target and vilgorous food-searching behaviour, lobsters grasping the $1 \mathrm{ip}$ of ther target with the maxilipeds. The filter paper plug was jammed in the vial to prevent ingestion by lobsters. On some 
35.

Table 7. Percentage frequency of NPC target captures by imature lobsters $(H$. americanus) $(n=23)$.

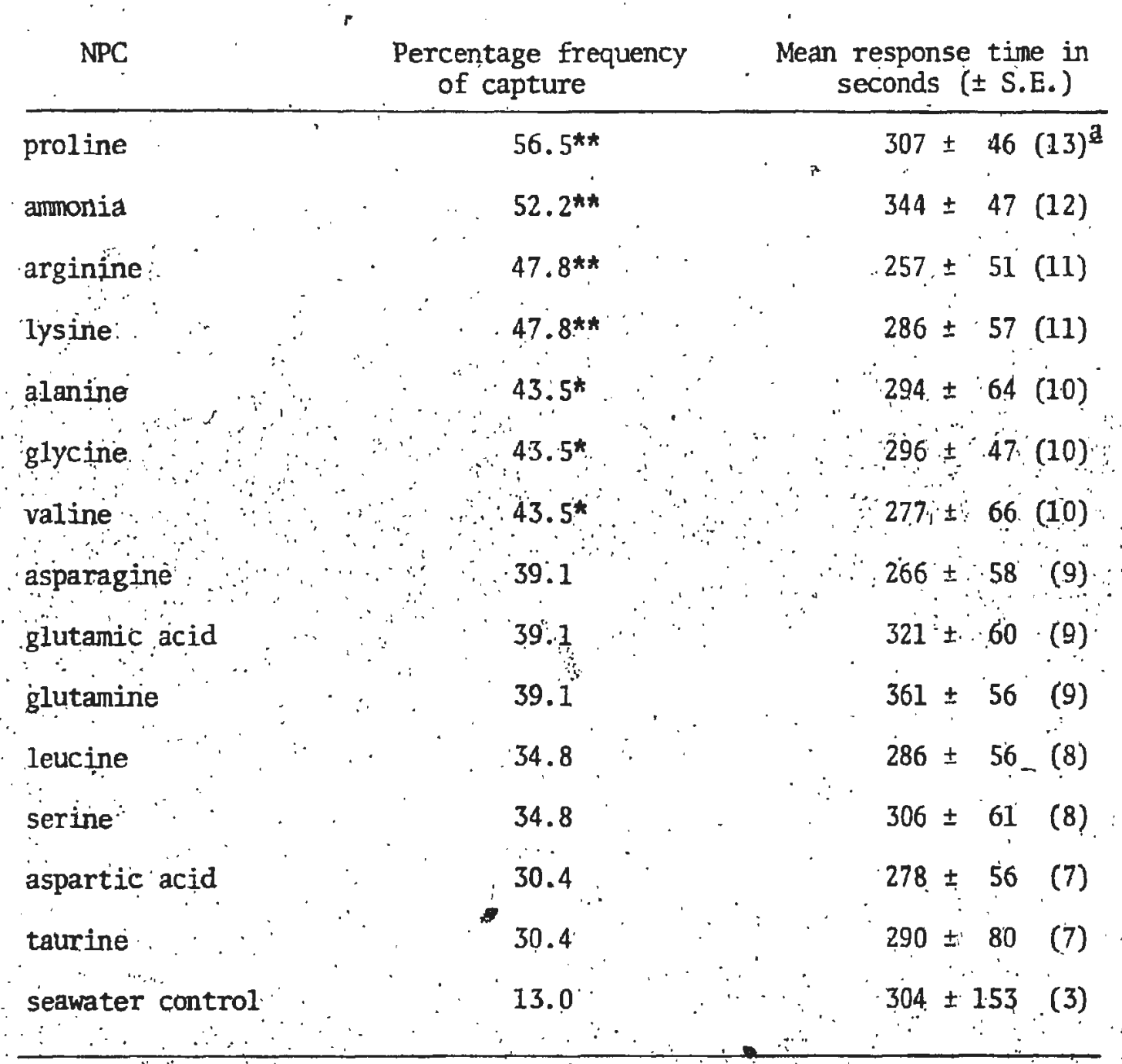

a. sample size

** significantly greater than control at $\mathrm{p}<0.01$

* significantly greater than control at p < 0.05 
occasions, the targets were abandoned and attacked severa1 times.

Mear time to target capture ranged from 257 'seconds for arginine to 361 seconds for glutamine: Mean time to target capture for all NPC's was 298 seconds. There was no apparent correlation between the percentage frequency of response and the mean time to target capture, indicating that a ten-minute observation period did not bias results by excluding responses to NPCs with slow diffusion rates or 10w solubilities.

Analysis of NPCs in prey tịssue extracts and effluents

$\therefore$ Resuits of NPC analysis of prey tissue extracts are noted in Table 8. (see APPENDIX B for additional details) A total of 43 NPCs were detected. Urea contributed a large and very variable amount, depending on the species, to the free NPC pool. Apart from urea, the most. concentrated NPCs generally were glycine, ammia, taurine, alanine, glu-: tamic acid, valine; leucine, and proline.

The highest total NPG concentrations (excluding urea, unknowns, trace amounts, and polyaminesj were detected in extracts of Nereis sp. and Cancer irroratus. Moderate lekels were recorded for extracts of Littorina littorea and Ophiopholis aculeata Lowest concentrations were observed in Mytilus edulis, Strongylocentrotus droebachiensis and Asterias vulgaris.

The most concentrated NPC (excluding urea) in the echinoderms Asterias and Strongylocentrotus was glycine Annonia, taurine, and ala nine contributed the next highest proportions to the total concentration of free. NPG in these echinoderms. In Ophiopholis tissue, the most concentrated NPCs were taurine, glycine; and amonia. . Littorina tissue had $\because+\infty$

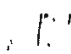


Table Mear concentrations of free ninhydrin-positive compounds (NPCs) (excluding urea, unknowns, trace amounts, and poiyanines) of prey tissue extracts as a percentage of the total NPC concentration. a

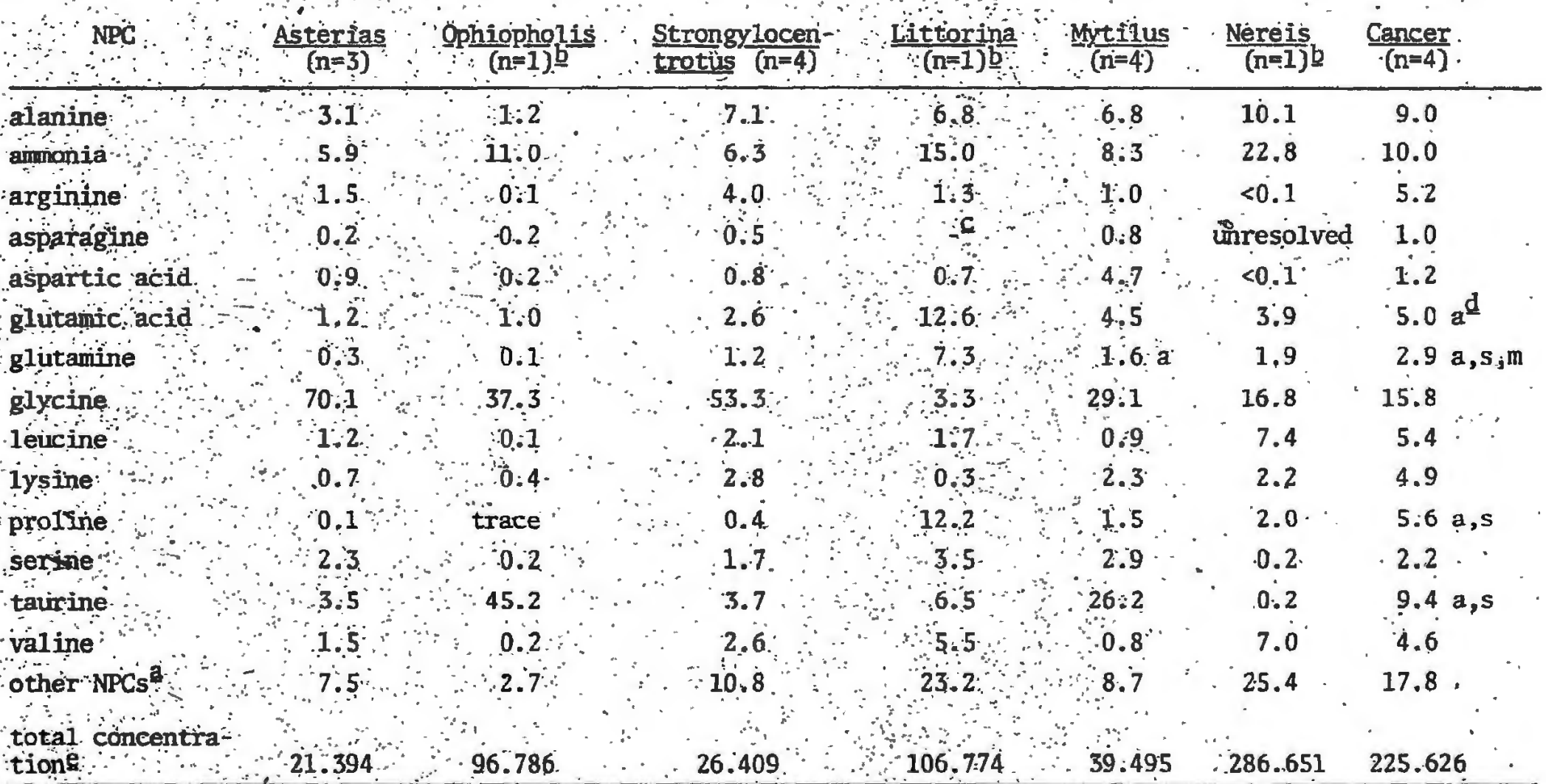
a see APPENDIX B for absolute concentrations af NPCs in prey tissue extracts
b one sample from eight individuals $\quad$ c not detected
d absolute concentration significantly greater than : a - Asterias s s - Strongriocentrotus; m - Mytilus $p<0$ os
imoles/ml 
high concentrations of amonia, glutamic acid, and proline. The most concentrated NPCs in Mytilus were glycine, taurine, anfonia; and alanine." In Nereis tissue, high concentrations of ammonia, glycine, alanine; leucine, and valine were observed. The most concentrated free NPCs (excluding urea) of Cancer tissue were glycine, amonia, taurine, alanine, and proline.

Few significant differences between individual NPC concentrations were observed because of smäl sample sizes Glutanine concentration was significantly haher in Cancer extract than in extracts of Aster ias, Mytilus, and Strongylocentrotus. Proline and taurine concentrations were significantly higher in Cancer extract than in Asterias and Strong ylocentrotus extracts. Glutamic acid concentration was significantly htgher in Cancer extract than in Asterias extract Giutanine and urea were significantly more concentratted in Mytilus extract than in extract of Asterias.

Polyamines contributed a very, smali amount to the totai free NPC pool of extracts. Concentrations were highest in extracts of littorina, Strongylocentrotus, and Cancer, and lowest in Asterias and Mytilus extracts.

The common NPC in prey effluents was ammonia (Table 9) Highest concentrations were recordet for Nereis $\$ p$ and Cancer irroratus. Ammonia concentration was moderate for Asterias effluent and low for Ophiopholis, Littorina, Strongylocentrotus and Mytilis only trace amounts of amonia were detected in seawater controls

Asterias was the only prey species to produce detectable amounts of NPCs other than amonia in effluent $A$ relatively high concentration of glycine was detected compared to very low concentrations of alanine, 
Tahie 9. Mean ninhýdrin-positive compound (NPC) concentrations (unoles/mi) of prey effluents in seawater.

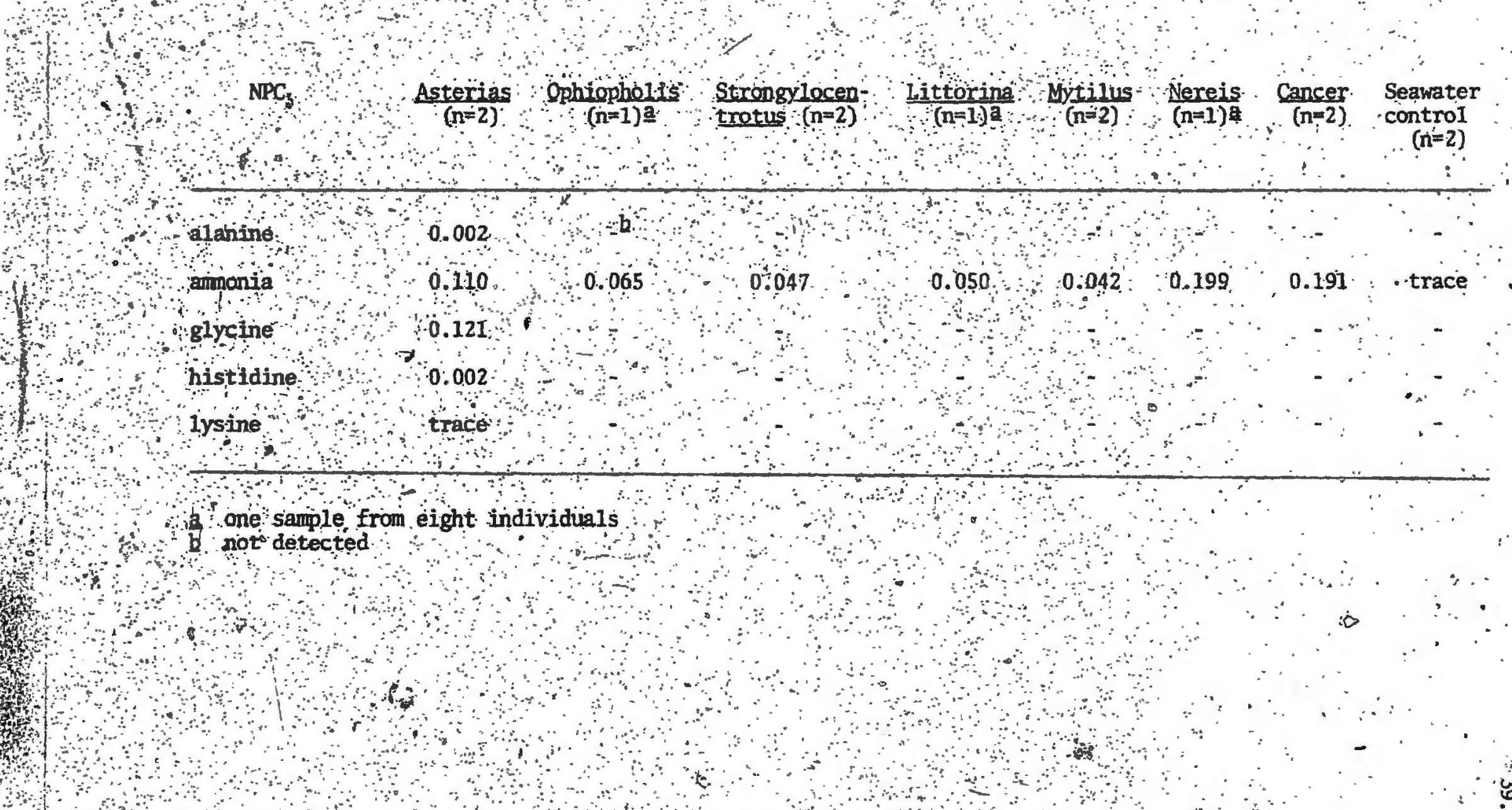


hîstidine, and lysine.

Controlled prey selektion

Percentage frequencies of attack were,greatest for Ophiopholis aculeata, Nereis sp., and Harmothoe sp. (Table 10). These prey were attacked significantly more often than either Strongylocentrotus droebachiensis or Littorina littorea. Moderate percentage frequẹcies of attack were recorded for Cancer irroratus, Asterias vulgaris, Mytilus edulis, and Strongylocentrotus droebachiensis and were significantly. greater than for Littorina which, was never attacked.

For all trials, the mean presumed rate of consumption of food by imature lobsters per trial was $4.69 \%$ ( $0.41 \%$ ) of lobster wet weight. Ratios of weight of prey residue to the wet weight of attacked prey are noted in Table 11. Consumption of Harmothoe' was apparently complete. In one trial, a few scales comprising a negligible amount of the' whole mass of the worm were not ingested. 'Presumed consumption of attacked. Nereis was comparable. Ratios of prey, residue to amount attacked for the poly- : chaetes were significantly smaller than values for all other attacked species. : The ration for Ophiopholis was significantly smaller than ratios. for Strongylocentrotus and Cancer, both of which were above 0.50 . Ratios of prey residue to amount attacked for Mytilus and Asterias were intermediate between Ophiopholis and Strongylocentrotus. Despite the apparent- ly low percentage consumption of Cancer, the mean amount presumably consumed per attack was substaritially, greater than such values for all other prey.

Consumption efficiencies (ratios of amount of prey presumably 
'Table 10. Percentage frequency of attack of various prey organisms by immature lobsters (H. americanus).

Prey organism ${ }^{\underline{a}}$

Mean wet weight of

n Percentage attacked

)

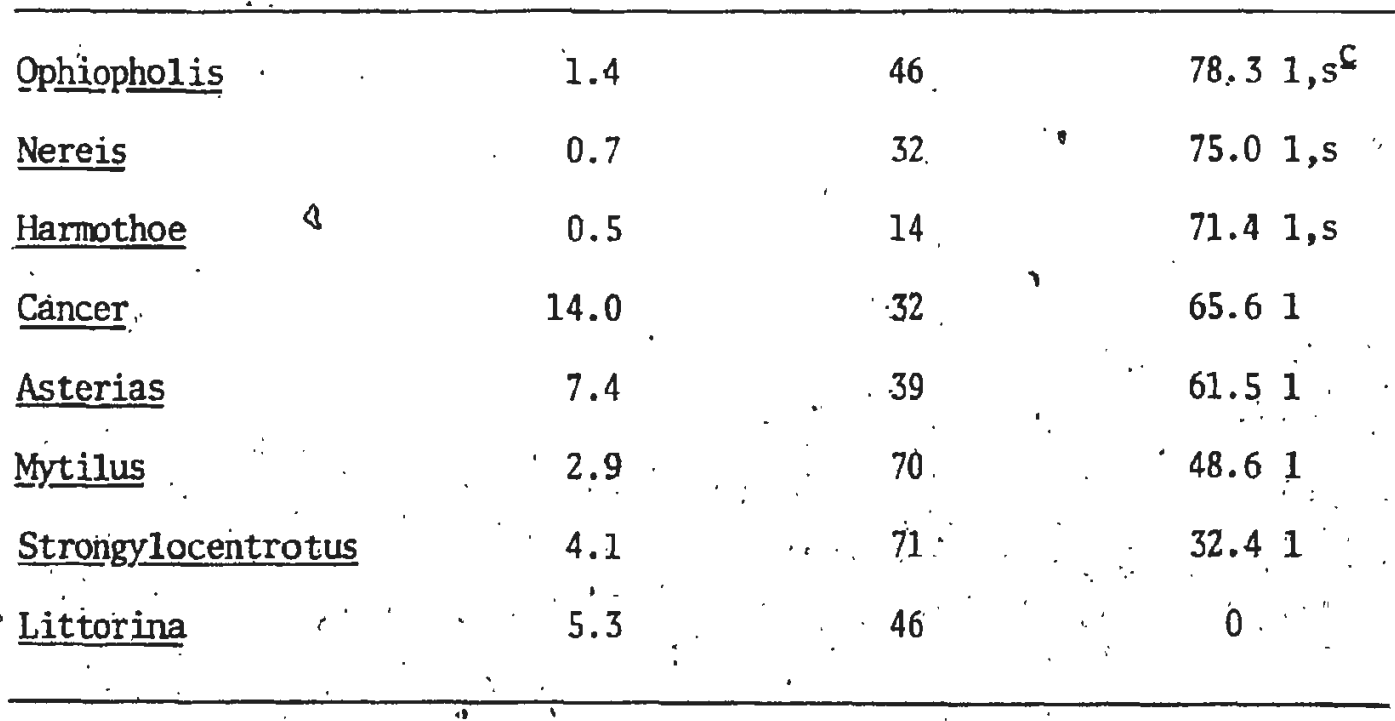

a offered simultaneously with various other prey organisms

b attack is defined as visible physical injury to prey organism

c significantly greater than: 1 - Littorina

\section{s - Strongylocentrotus}

$$
p<0.05
$$


Table 11. Ratios of weight of prey residues (unconsumed) to wet weight of prey attacked by immature lobsters (H. americanus).

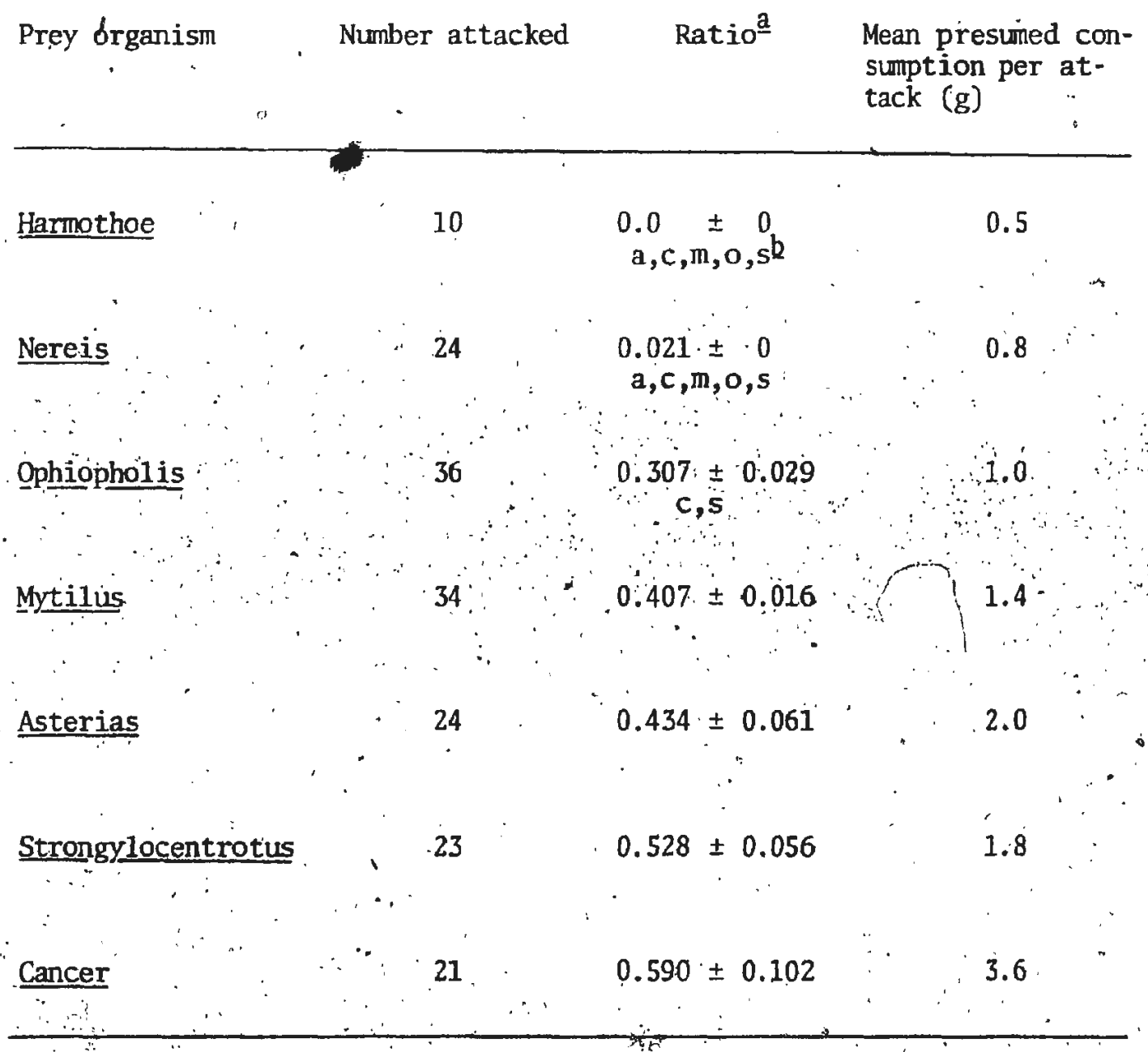

a mean \pm standard error

b significantly. smiller than: a Asterias

c - Cancer

in - Mytilus

o - Ophiopholis

$p<0.05$

s - Strongylocentrotus 
43.

consumed to amount offered) are noted in Table 12. Highest values were recorded for Nereis and Harmothoe, the former being significantly greater than values for all other species offered, with the exception of Har-" mothoe, and the latter significantly greater than values for all spectes except Nereis and Ophiopholis. Consumption efficiency was considerably lower for Ophiopholis compared to polychaetes, although significantly greater than values for all species with lower efficiencies. Cọnsumption efficiency was, very low for Strongylocentrotus. Despite relatively. low efficiençies for Astexias and Cancer, the mean amounts of these tar-. ger speciés presumably consumed per trial were relatively high (Table $\left.{ }_{\circ} 12\right)$ : At tacked and ignored prey individuals were classified according to percentage of lobster wet weight to obtain an indication of prey. size influence on attack rate (Table 13). Lobsters attacked individuals (Cancer) up to at least $17.69 \%$ of their own mass and as small as $0.91 \%$ (Nereis). There was a significant difference in mean size between the small size class of ignored Cancer individuals and the class of attacked Gancer individuals. Therẹ were significant differences in mean sizes between the large size classes of ignored individuals of Asterias, Strongylocentrotus, and Mytilus and the respective attacked classes.

Uneaten portions of prey from 'all trials were observed to determine mode of consumption. Uneaten portions of Mytilus were comprised of many fragments of she11, usuaily stripped of tissue. A small amount of shell appeared to have been consumed (Figure 5). The sizes of she11 fragments "suggested that Mytilus individuails were crushed open by the claws, rather than chipped open by the mandibles.

Uneaten portions of Cancer individuals frequently includèd compiete legs and claws broken from the main body (Figure 6), althouigh, 
Table 12. Consumpition efficiency of immature lobsters (ㅂ. americanus) offered various prey organisms.

Prey organism

$$
\begin{aligned}
& \text { Mean wet weight } \\
& \text { of offered prey } \\
& (\mathrm{g})
\end{aligned}
$$

$$
+
$$

Nereis

0.7
$(32)^{\stackrel{c}{c}}$

$0.734 \pm 0.078 d$
$: a, c, 1, m, o, s$

0.59

Hairmothoe

0.5

$0.714 \pm 0.125$

0.37

Ophiopholis

1.4

(46)

$0.542 \pm 0.067$

$a, c, 1 ; m, s$

Asterias

7.4

$0.349 \pm 0.066$

1.21

0.79

$\because 1, s$

Mytilus

2.9

$0.288 \pm 0.037$
1,5

0.67

Cancer

14.0

(32)

$0.269 \pm 0.058$

Strongylocentrotus

(7i)

$0.153 \pm 0.031$

0.58

Littorina

5.3

4.1

, $\cdots$
Mean presumed consumption per trial (g) efficiencyb 
Table 13. Sizes of attacked and ignored prey organisms as a percentage of immature lobster (․ㅡ. americanus) wet weight.



mean \pm standard error

b small size class $=$ organisms smaller than mean size (as a of lobster wet weight) of attacked individuals

large size class = organisms larger than'mean size (as a $\%$ of lobster wet weight) of attacked individuals

* significantly different from mean size of attacked individuals 


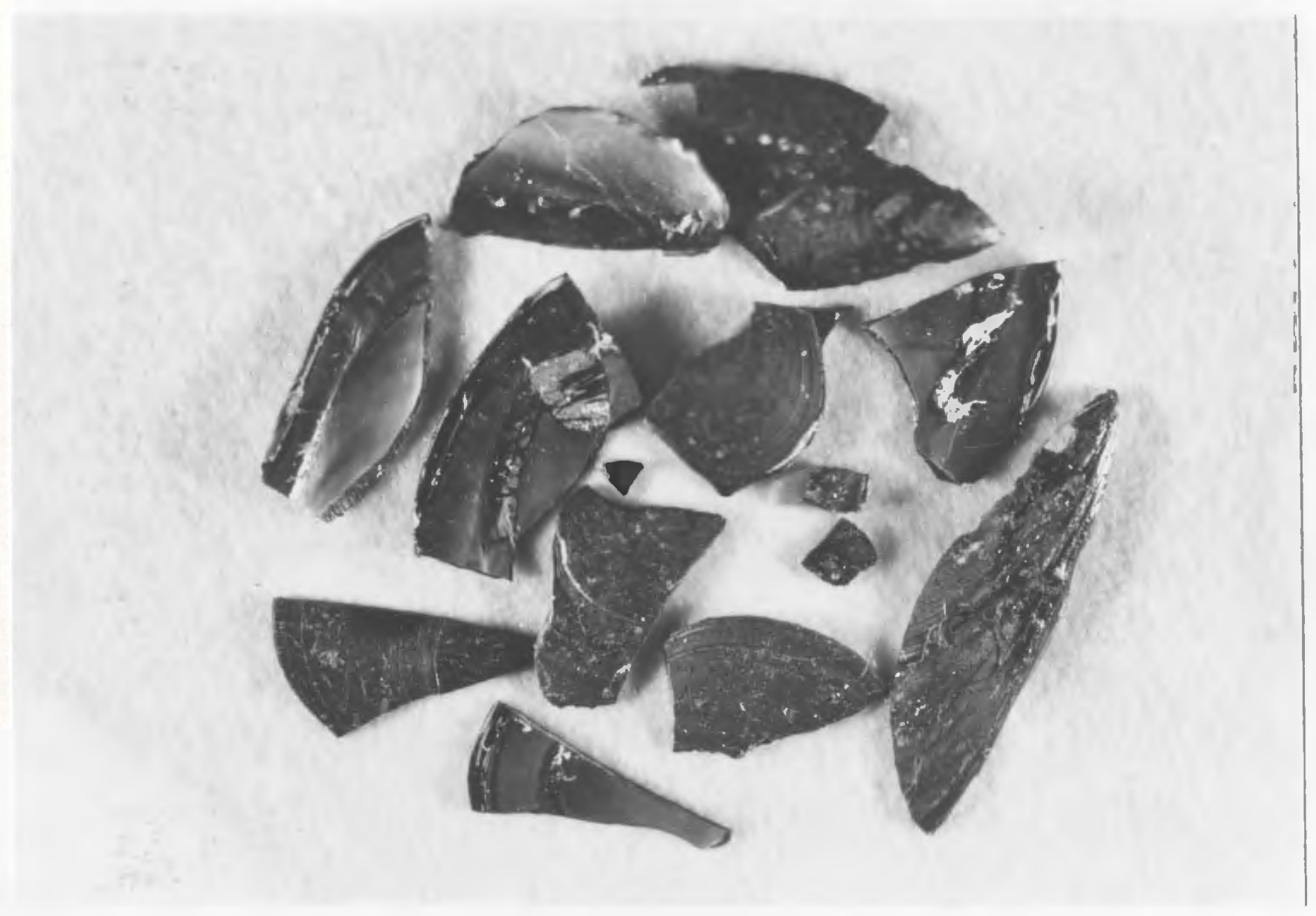

Figure 5. Remains of Mytilus edulis after feeding by an immature 1obster (ㅂ. . americanus) (x 2.5). 


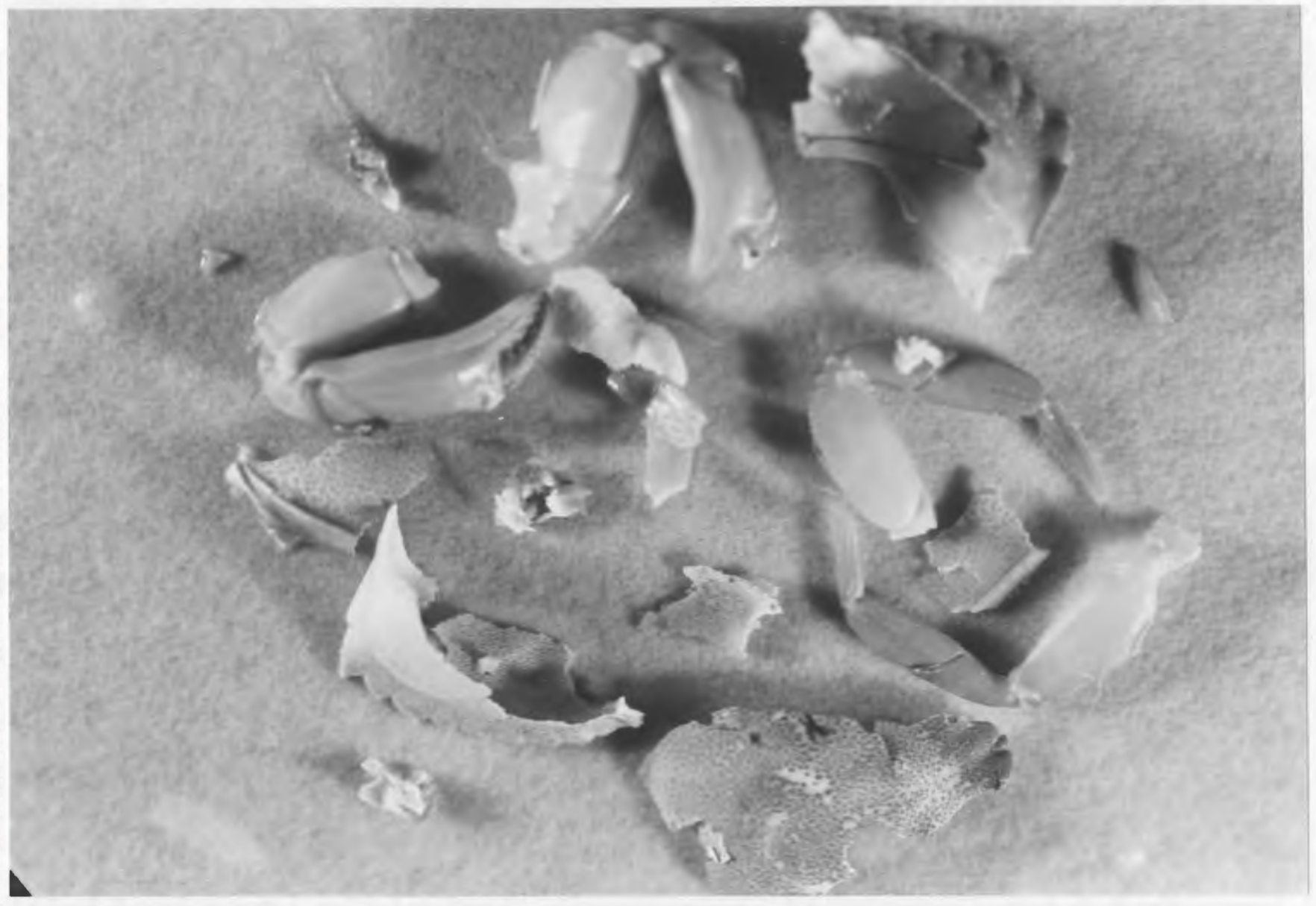

Figure 6. Remains of Cancer irroratus after feeding by an immature lobster (ㅂ. americanus) ( $\left.\begin{array}{ll}x & 2\end{array}\right)$. 
in most cases, several legs had been consumed. The carapace was generally fragmented and cleaned of tissue.

Uneaten portions of Strongylocentrotus commonly included large pieces of the test (Figure 7), most of which were stripped of tissue. Few spines appeared to have been consumed. Uneaten portions of Ophiopholis consistently included tips of arms. Remains of Asterias general1y consisted of whole arms.

Gut content analysis.

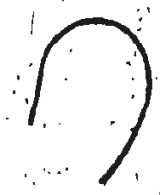

The remains of at least 33 taxa were observed in guts of immature lobsters collected in Placentia Bay between June and November. The most frequentiy occurring species were Strongylocentrotus droebachiensis; Mytilus edulis, Cancer irroratus, polynoids, Nereis sp., and Ophiopholis aculeata (Table 14), The number of mollusc species was fairly high, although percentage frequencies of occurrence of individual species were 10w. Approximately' $20 \%$ of lobster guts contained unidentified hard parts of bivalves, crustaceans, gastropods, and polychaetes. Various items of questionable nutritional value, such as pebbles, sand, wood, rubber, and plastic were observed as well. Characteristic hard parts of the yarious consumed species are noted in APPENDIX C. Contents of individual immature lobster guts are shọn in Figures 9-14.

The most abumdant gut items (in tems of relative volumes of hard parts) were Cancer irroratus, Ophiopholis aculeata, Mytilus, edulis, Nereis sp, polynoids, and Strongylocentrotus droebachiensis. Percentage frequency of occurrence of Homarus americanus as dominant gut item was relatively high during the moulting period from mid-August to mid: 


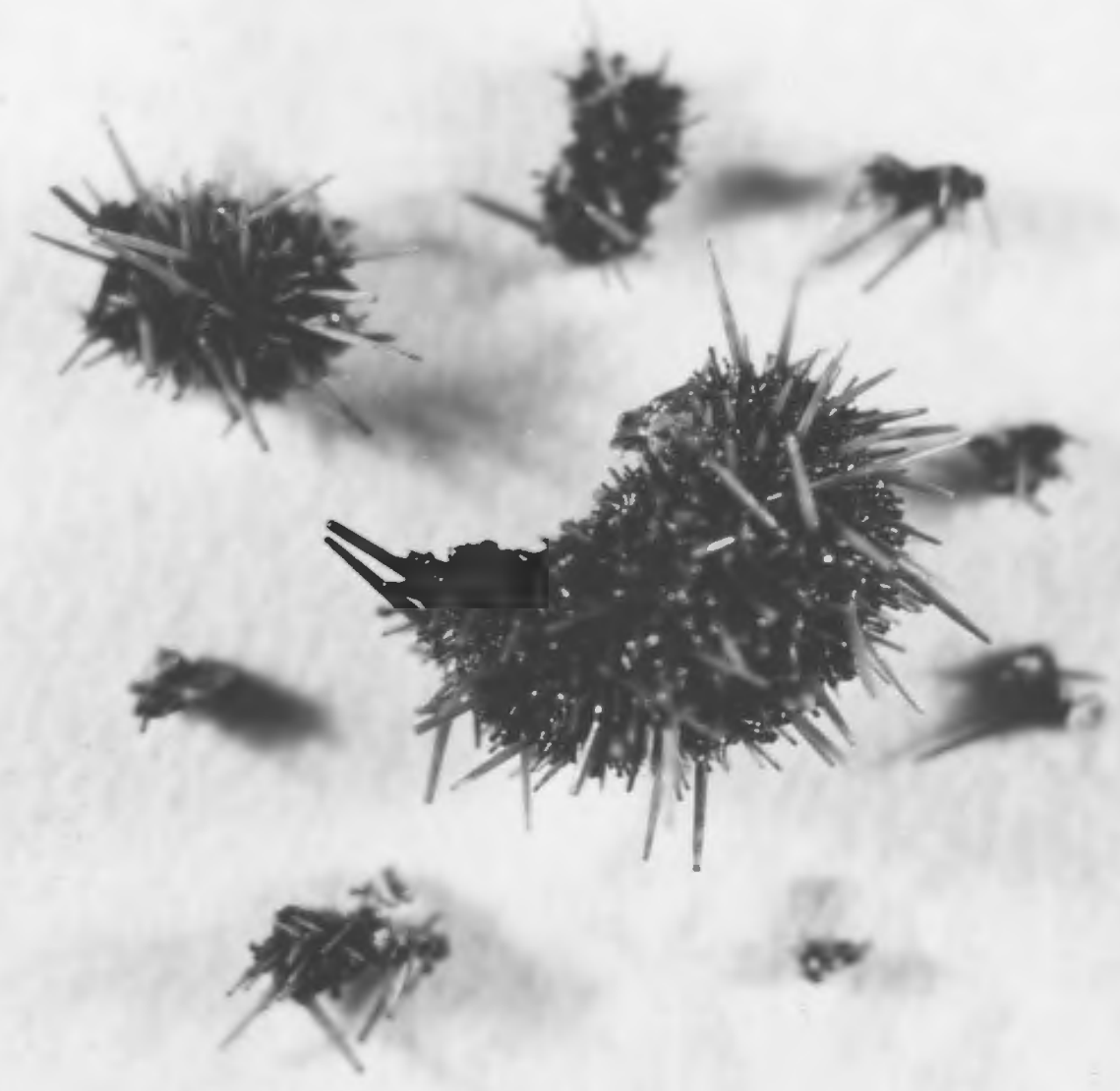

Figure 7. Remains of Strongylocentrotus droebachiensis after feeding by an immature lobster (ㅁ․ americanus) (x 2.5). 
Table 14. Percentage frequency of occurrence of items in guts of immature lobsters $(H$. americanus) from Placentia Bay in sumner and fa11 $(n=103)$.

Gut item

$\frac{7}{5}$ frequency of occurrence

$\&$ frequency of occurrence as dominant gut item

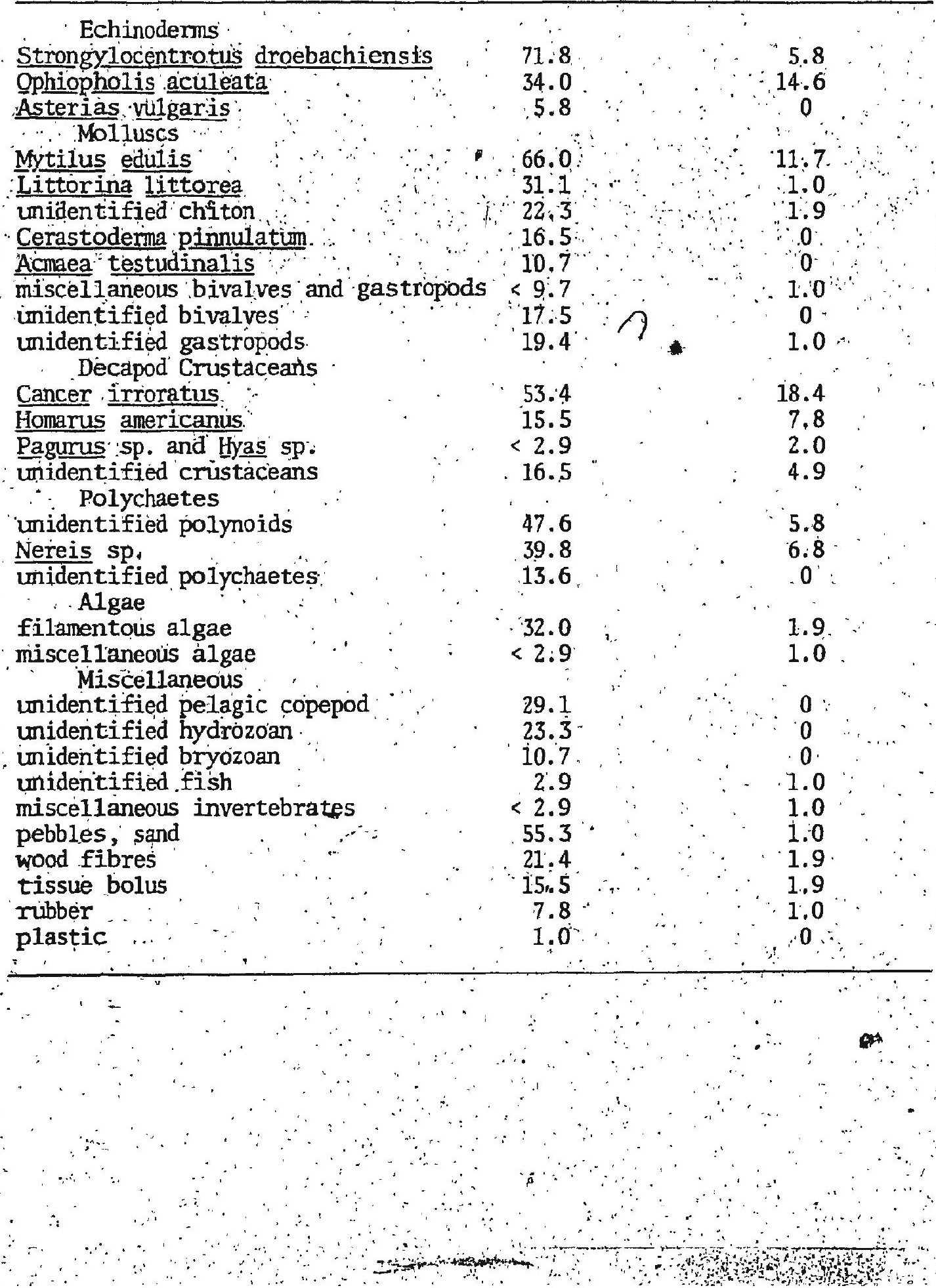


51.

September (seje APPENDIX D).

When occurring, crustacean species such as Cancer irroratus, Homarus americanus, Pagurus arcuatus, Hyas araneus, and an unidentified amphipod contributed a large percentage to the total volume of gut contents (Table 15). The same was true, although to a lesser extent, for midentified crustacean material. Ophiopholis aculeata contributed a sizeable percentage of the total volume of gut contents when it occurred.. Snaller contributions to the total volume of gut contents were made by Mytilus edulis, Asterias vulgaris, Neseis sp, chiton, strongylocentrotus droebachiensis, and polynoid polychaetes when they occurred

The estimated percentage contribution to the total volume of the inmature lobster population diet from Jine to November was calculated by multiplying the percentage frequency of occurrence of individual gut ittems by the estimated mean percentage contribution of the item to the total volume of gut contents when occurring (Table 15). The most important items in the inmature lobster diet by this reckoning are Cancer irroratus, Mytilus edulís, Ophiopholis aculeata : Strongylocentrotus droebachiensis, Lobster exuriae, Nereis sp; and polynoid polychaetes. The estimated percentage contributions of various taxa to the total volume of the immature lobster population diet are shown in Figure 8

Seasonal differences in the percentage frequencies of occurrence of gut itemis are noted in Table 16. Percentage frequency of occurrence of Cancer irroratus in lobster guts was significantly higher in late summer than in early sumer and fall. The same was true for inci dence of Homarus hard parts in guts. Elevated percentage frequencies of occurrence in late sumer were recorded as well for polynoids, chitons, Lacuma vincta, Littorina 1ittorea, inidentified bivalves, and Strongylo- 
Table 15. Estimated contributions of prey items to the immature lobster (H: americanus) diet.

Gut item

Echinodernis

Strongylocentrotus droebachiensis Ophiopholis aculeata Asterias vulgaris

Moliuscis

Mytilus edulis

Littoring littorea

unidentified . chitón

Cerastoderma pinnulatim

Acmaea testudinális

misce 1laneous bivalves and gastropods.

inidentified bivalves

unidentified gastropods Decapod Crustaceans

Cancer : irroratus

Homarus americanus

Pagurus sp. and Hyas sp.

unidentified crustaceans

Polychaetes

unidentified polynoy̆ds

Nereis sp.

unidentified polychaetes. Algae

filámentous aligae

miscellaneous álgae

Miscellaneous

unidentified pelägic copepod

unidentified hydrozoan

inidentified bryozoan

unidentified fish.

misce11aneous inyertebrates.

pebbles, sand

wood Eibres

tissue bolus:

rubber

plastic.

amorphoús material
Estimated mean \&. Estinated \& contricontribution to bution to total voltotal volime of gut contents whęn occurring une of population diet
9.2

33.3

18.7

17.6

4.2

11.1

5.4

3.7

$<13.7$

8.8

2.7

$27: 8$

42.6

$<52.5$

21.1

8.9

15.4

4.4

6.1

$<20.0^{\circ}$

:1.1

1.7

3.1

20.0

$<60.0$

2.8

19.6

20.0

10.3

$1.0^{\circ}$
66

111.3

1.1

1.1 .6

1.3

2.5

0.9

0.4

1.2

1.5

0.5

14.8

6.6

1.8

3.5

$4: 2$

$6: 1$

0.6

2.0

0.6

0.3

0.4

0.3

0.6

0.8

1.5

4.2

3.1

0.8

0.1 

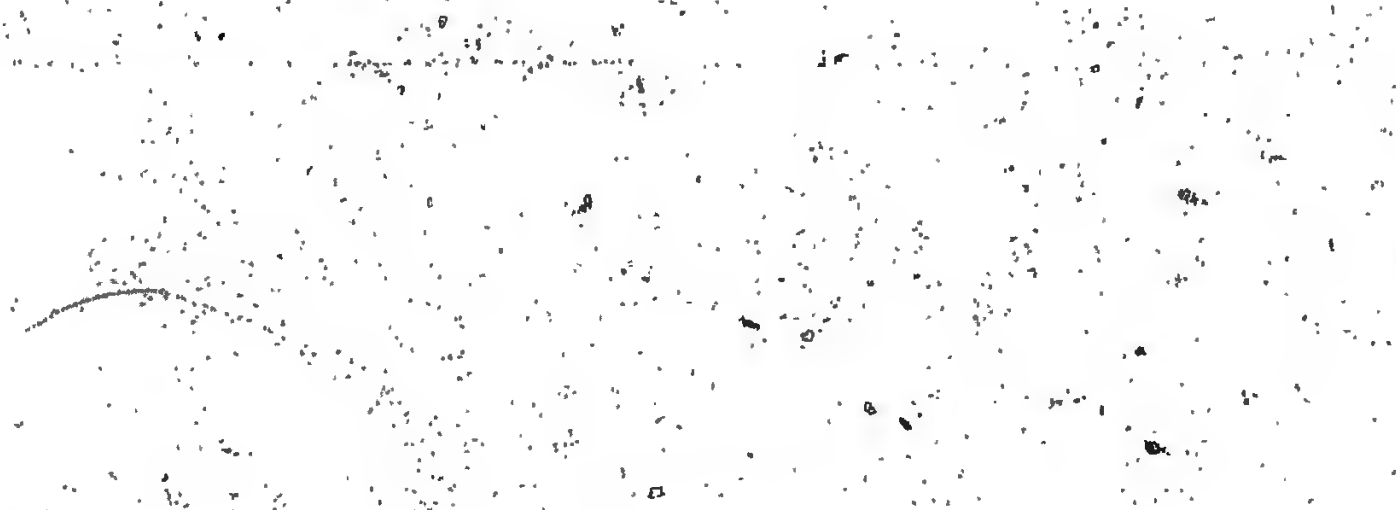

53

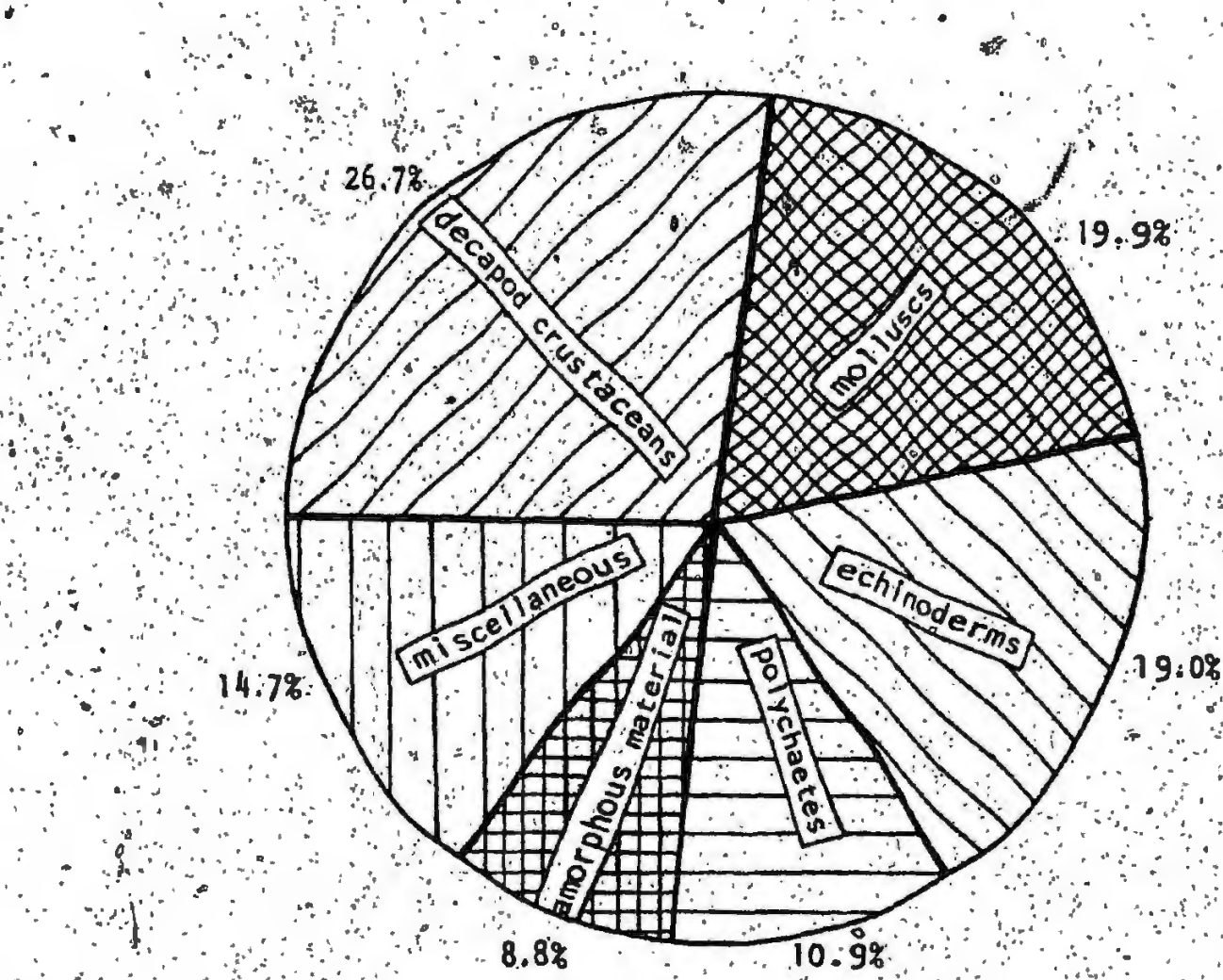

2.

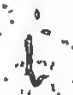

7

Figure 8 Estimated percentage contribution of the main taxononic groups to the total volume of the immatime Iobster (H americanus popuiation diet." 
Table 16. Seasonal differences in percentage frequency of occurrence of gut items of immature lobsters $(\underline{H}$. americanus) from Placentia Bay.

Gut item
A

June to

mid-Aug.

$(\mathrm{n}=46)$

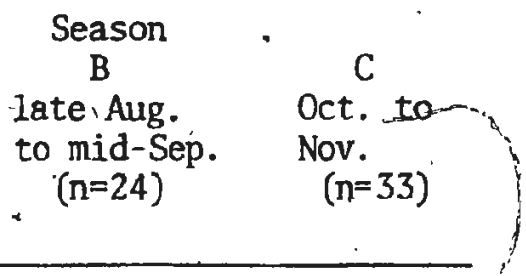

Echinoderms

Strongylocentrotus droebachiensis Ophiopholis aculeata

Asterias: vulgaris Molluscs

Mytilus edulis

Littorina 1ittorea

unidentiffied chiton

Cerastoderma pinnutatum

Aćmaea testudinalis

miscellaneous'bivalves/gas tropods

unidentified bivalves

unidentified gastropods

$\therefore \quad$ Decapod Crustaceans

Cancer irroratus

Hómarus americanus

Pagumis sp. and Hyas sp.

unidentified crustaceans Polychaetes

unidentified polynoids

Nerèis sp.

inidentified polychaetes Algae

filamentous algae

miscellaneous algae Miscellaneous

unidentified pelagic copepod

unịdentified hydrozoán

unidentified bryozoan

unidentified fish

miscellaneous invertebrates

pebbles, sand"

wood fibres

tissua bolus

rubber

plastic
73.9

26.1

6.5

50.0

8.7.

15.2

.17 .4

$17.4 \mathrm{C}$

$\leq 13.0$

6.5

15.2

28.3

8,7

4.3

$21.7 \mathrm{~B}$

28.3

34.8 .

15.2

$56: 5$ B, C

$<4.3$

34.8

$19: 6$

19.6 C

$4.3:$

<.6.5

78.3 B,C

23.9

17.4

2.2

2.2

$87.5 \mathrm{C}^{\mathrm{a}}$
50.0
0

$57: 6$

$33: 3$

9.1

\section{0}

$.58 .3 \mathrm{~A}$

45.8 A,C

16.7 :

12.5 .

$<16.7$

$45.8 \mathrm{~A}$

29.2

$91.7 . \bar{C}, \quad-60.6 \mathrm{~A}$

$50.0 \mathrm{~A}, \mathrm{C}$

0

8.3

91.7 A,C

62.5

4.2

$81.8 \mathrm{~A}$

$42.4 \mathrm{~A}$

15.2

15.2

0

3.0

18.2 .

12.1

$<3.0$

15.2

42.4

30.3

18.2

12.1

12.5

4.2

$<3.0$

33.3

$33: 3$

16.7

8.3

4.2

$\therefore 0$

37.5

$12: 5$

8.3

20.8
0

$\therefore 0$

$<3.0$

36.4

24.2

18. 2

6.1

a significantly greater than: $A=$ June to mid-August: $B$ late August to mid-September; $C=$ October to November $p<0.05$ 
centrotus. High percentage frequencies of occurrence in inmature lobster guts in early sumer relative to 6 ther seasons were observed for unidentified crustaceans, Acmaea testudinalis, Lacuna vincta, bryozoans, and filamentous algae. Cancer irroratus, Littorina -1ittorea, and Mytilus edulis were more common in lobster guts in fall than in early summer.

No inmature lobster guts were, completely empty, although some had only a few hart parts of animals remaining. There were no significant differences in git fuilness estimates between seasons (early summer, late sumner, fall) (Table 17). '

Residency of prey hard parts in guts of immature lobsters is noted in Tabie 18 . The general indication is that prey hard parts can re-" main in the gut 'for over 90 days. Mollusc and crustacean shel1, and poly-: chaete jaws are apparently not easily digested or evacuated. Hard parts of polychaetes were observed in guts of lobsters 180 days after last natural feeding.

Clearance of gut contents of immature lobsters on single species ad Libitum diets is noted in Table 19. Ratios of gut content wet weight to lobster wet weight one day after feeding were $1.7 \%$ and $1.3 \%$ for Cancer and Strongylocentrotus diets respectively. Rate of clearance is inferred from comparison of vàlues for lobsters at different stages of food deprivation. Clearance of the 'gut showed an apparent negative linear relationship to duration of food deprivation: The rate of gut clearance was greater for lobsters fed a diet of cancer than for those fed Strongylocentrotus. After three days of food deprivation, ratios of igut content dry weight to lobstèr wet weight for all lobsters were similar, ranging from 151.10 $x \cdot 10^{-5}$ in lobsters fed Cancer to $181.45 \times 10^{-5}$ in those fed Strongylocentrotus: 
56.

Table 17. Various estimates of gut fullness of imature lobsters $a H$. americanus) from Placentia Bay by season. ${ }^{\text {a }}$

Estinate of gut fullnèss $k$

1
Season

late Aug. Oct. to

to mid-Sep. $(\mathrm{n}=24)$
Nov.

$(n=33)$

Ratio of gut content wet

$0.0099 \pm 0.0009$

$0.0101 \pm 0.0013$

$0.0076 \pm 0.0010$ weight to lobster wet weight

Ratio of gut content dry $\cdot 323.36 \pm 37.52=316.21 \pm 59.12 \quad 195.35 \pm " 33.54$ weight to lobster wet." weight $\times 10^{5}$

Ratio of gut content dry $968.92 \pm 101.771011 .32 \pm 185.16$

$896.03 \pm 152.05$ volume to lobster wet weight $\times 10^{5}$

Visual index of gut fullness ${ }^{2}$

$1.89 \pm 0.21$

$2.04 \pm 0.29$

$1.73 \pm 0.21$

a mean \pm standard error

b based on a scale of 0 to 4 (empty.to full) 


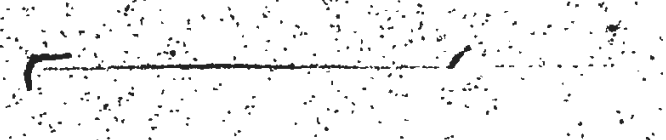

Table 18. Residency of prey hard parts in guts of immature lobsters (H. americanus).

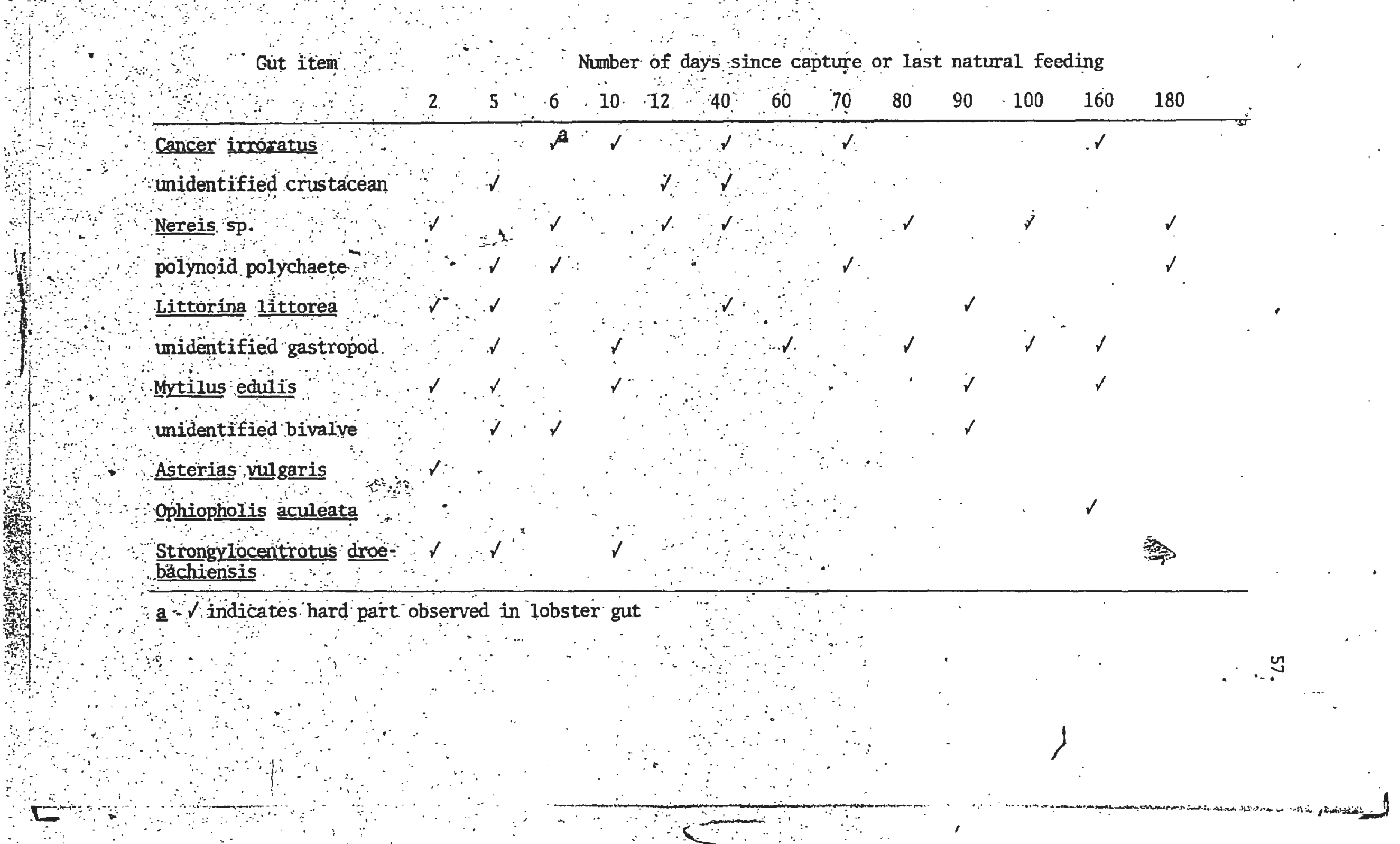


Table 19. Clearance of gut contents of imature Iobsters (H: americanus) at $8^{\circ} \mathrm{C}$. as indicated by various estimates of gut fullness

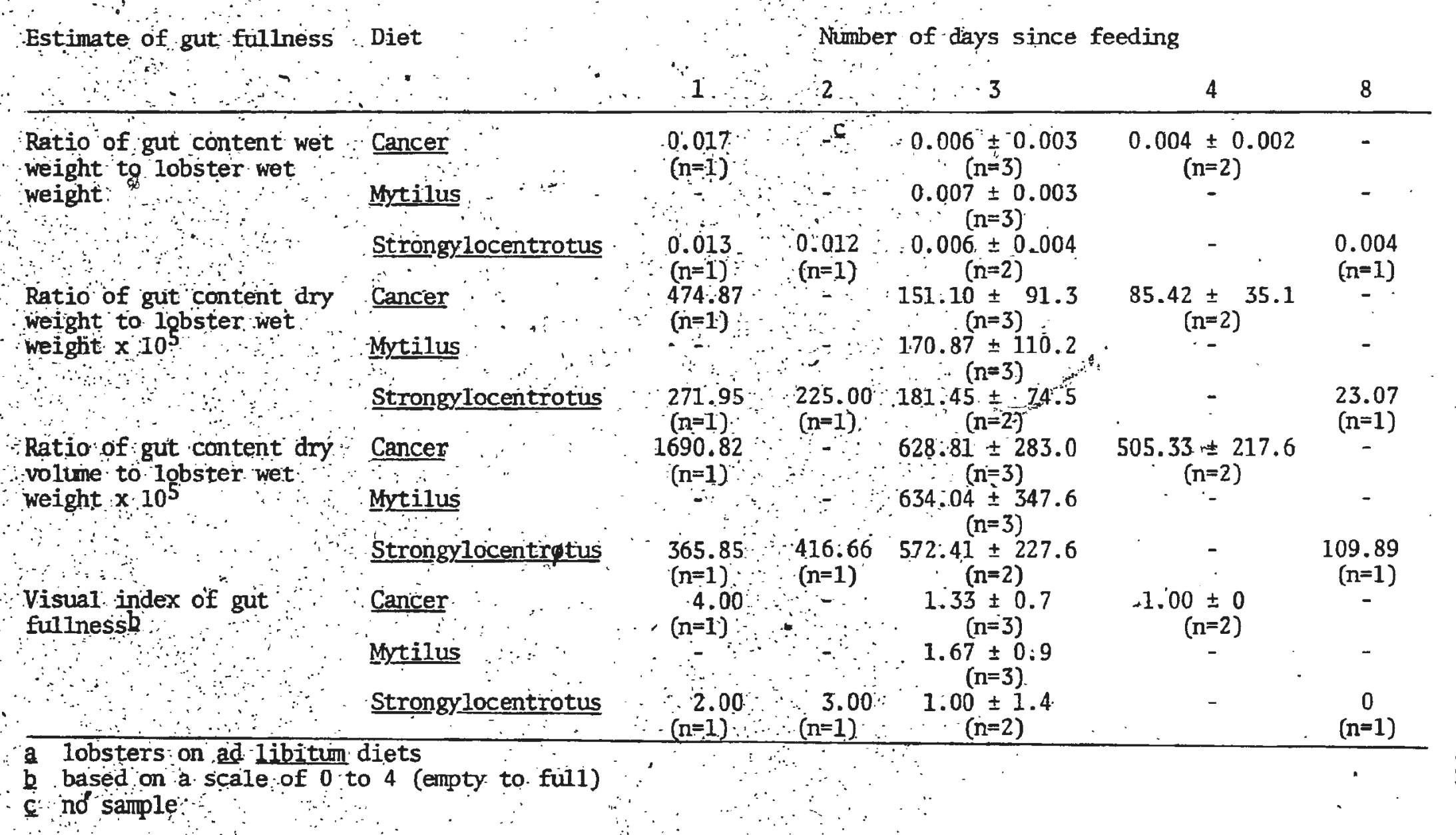


59.

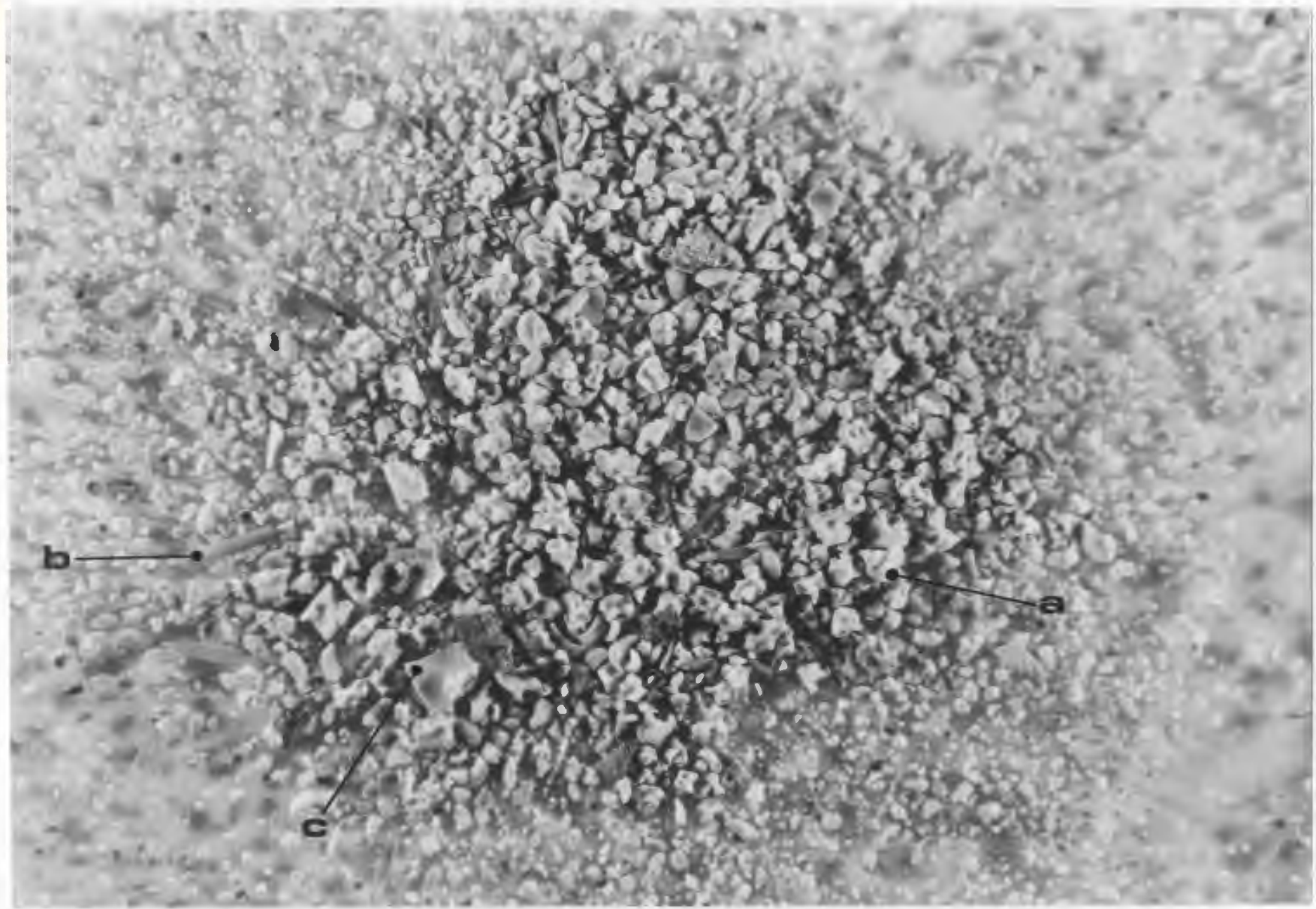

Figure 9. Gut contents of an immature lobster (ㅂ. americanus) with a high incidence of remains of Ophiopholis aculeata (x 4).
a - Ophiopholis vertebra
b - sea urchin spine
c - part of bivalve shell 


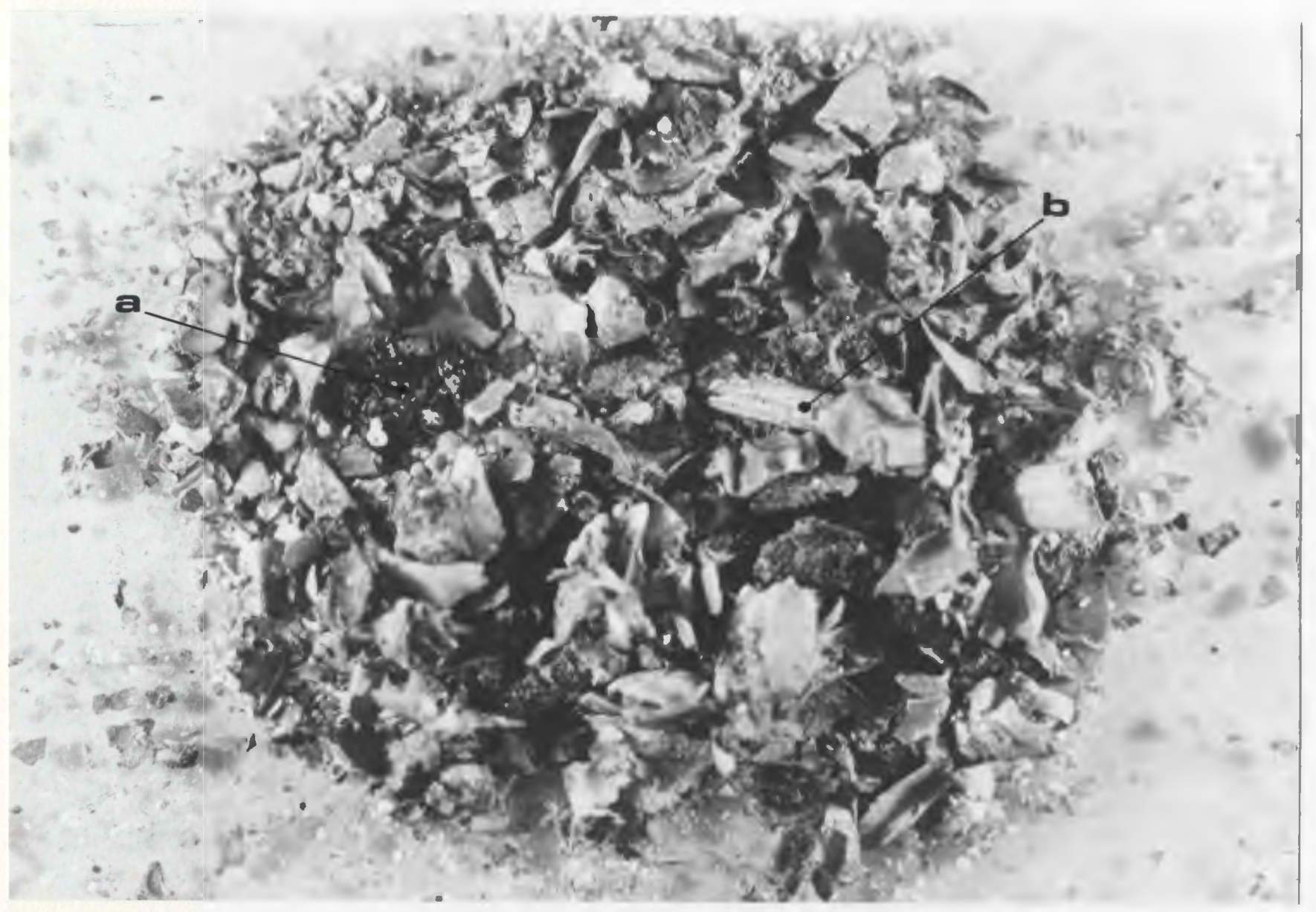

Figure 10. Gut contents of an immature lobster (H. americanus) with opercula of Littorina littorea and remains of Cancer (x 3). a - operculum of Littorina littorea b - pereiopod of Cancer irroratus 


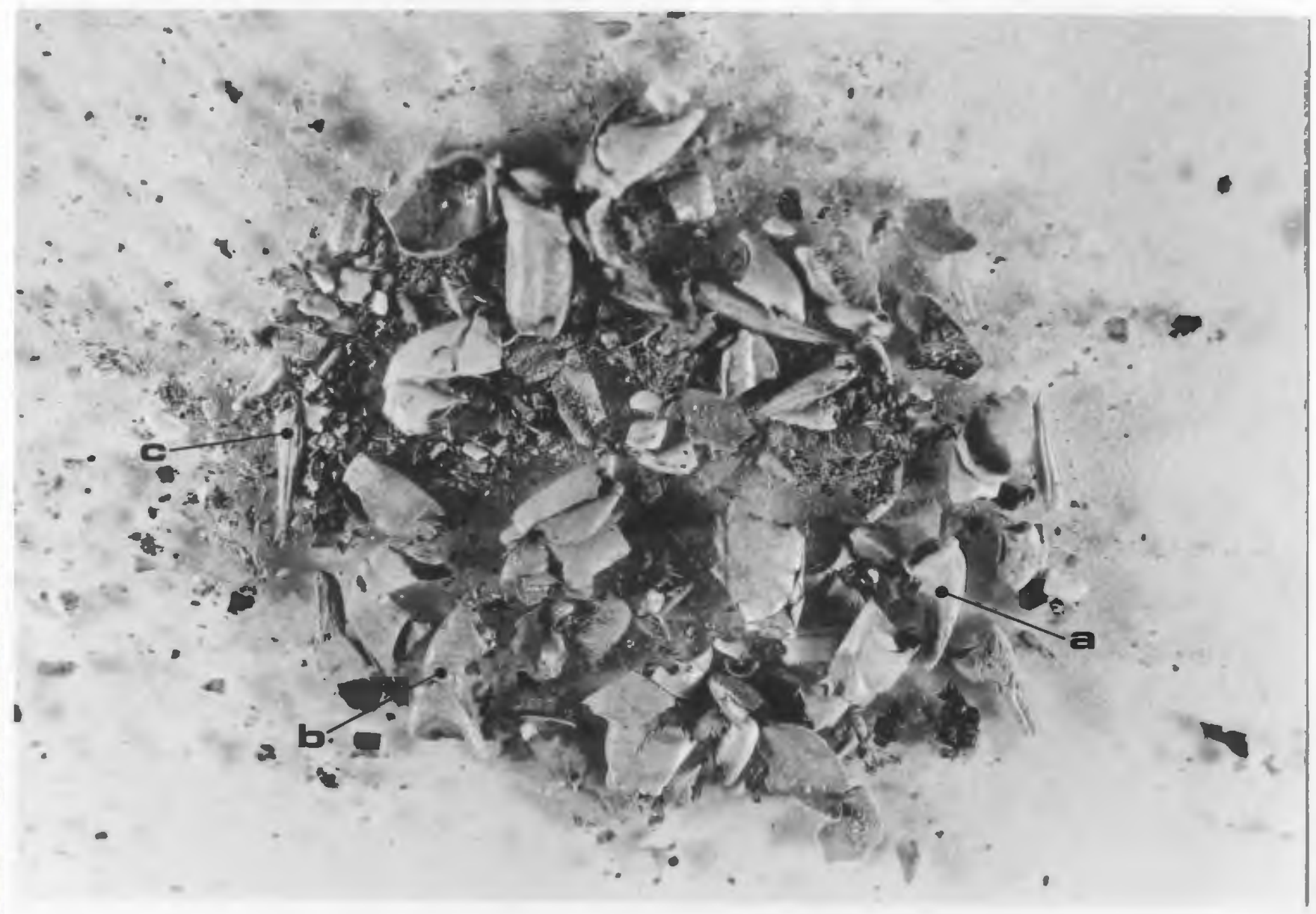

Figure 11. Gut contents of an immature lobster (H. americanus) with a high incidence of Cancer irroratus remains (x 3 ).
a - part of claw
b - portion of knuckle
c - tip of pereiopod 


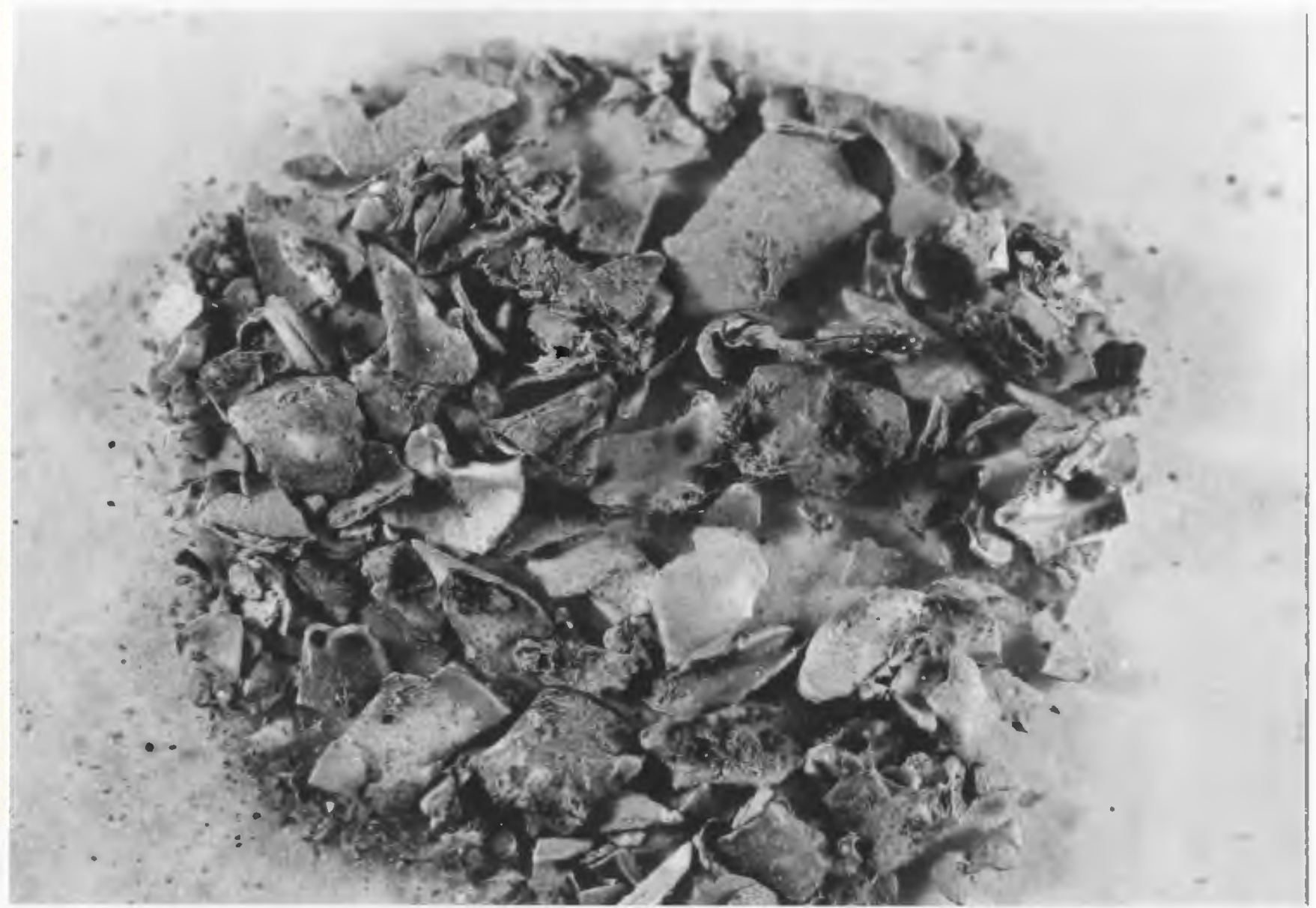

Figure 12. Gut contents of an immature lobster (H. americanus) with a high incidence of lobster exuviae (x 3). 


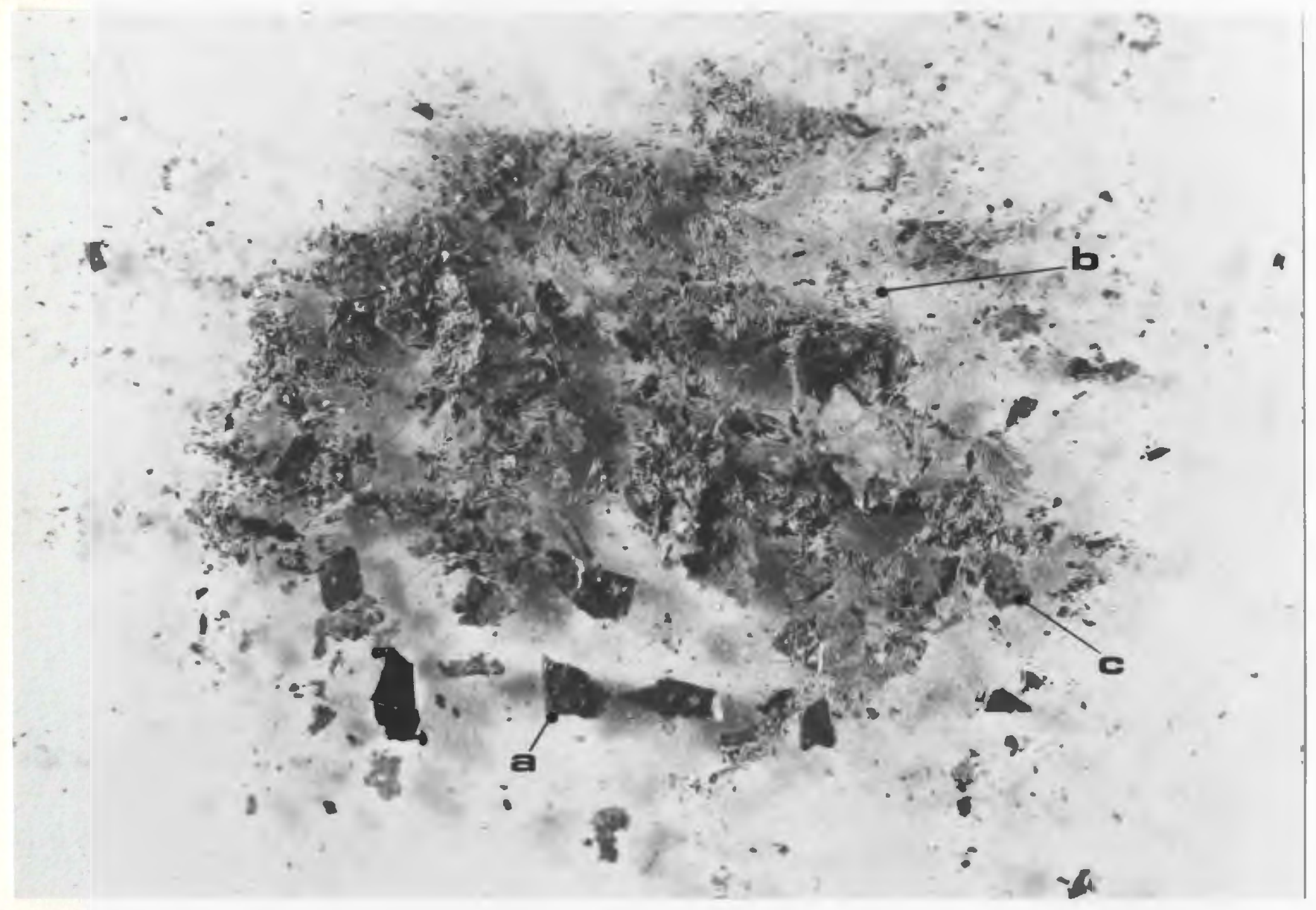

Figure 13. Gut contents of an immature lobster ( $\underline{H}$. americanus) recently feeding on Mytilus edulis (x 3).
a - piece of shell
b - byssal threads
c - Mytilus tissue 
64.

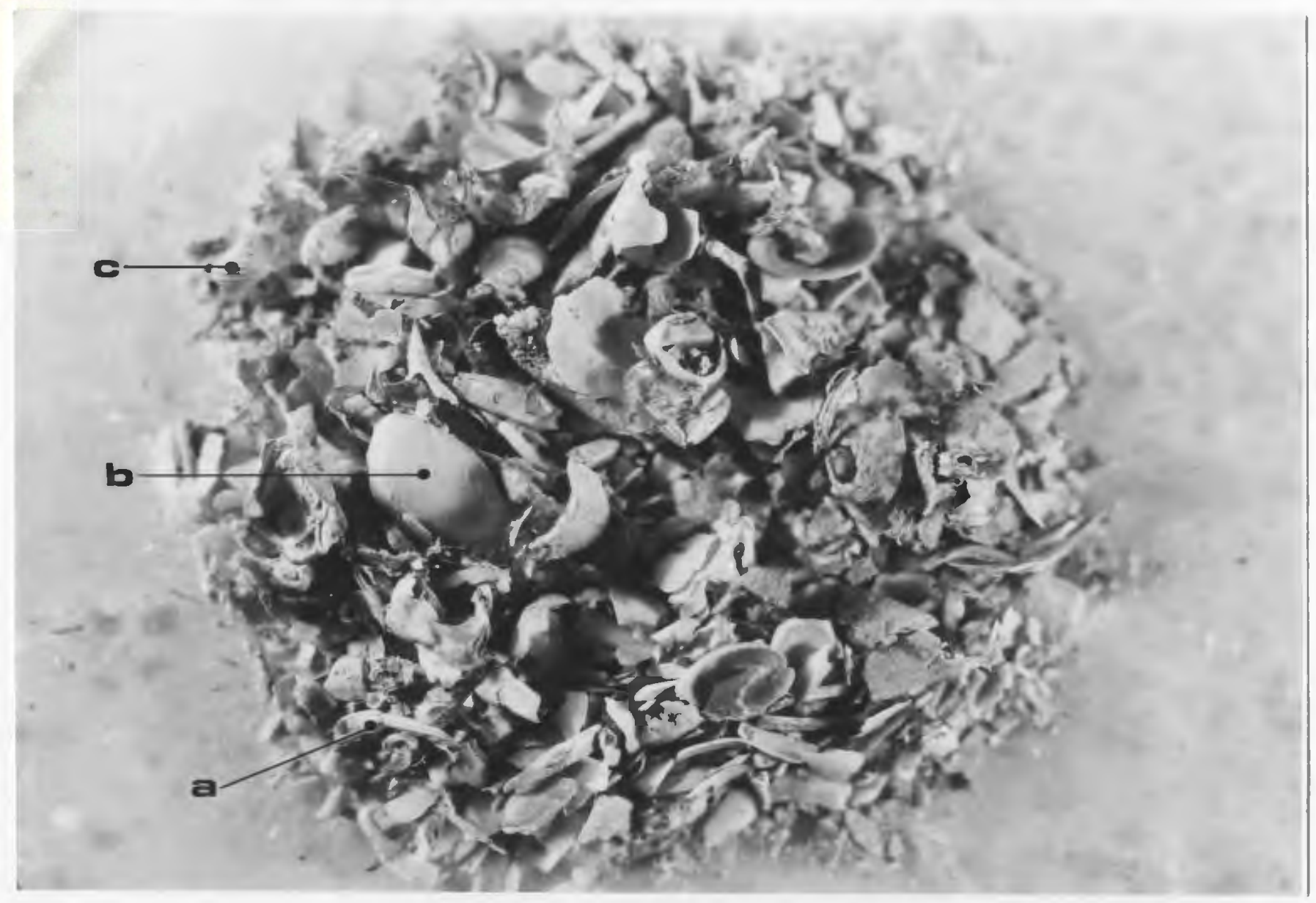

Figure 14. Gut contents of a recently moulted immature lobster (므. americanus) with a high incidence of Cancer remains and mollusc she11s ( $\left.\begin{array}{ll}x & 3\end{array}\right)$.
a - tip of pereiopod of Cancer
b - bivalve she1l
c - gastropod shell 
65.

Prey density in Placentia Bay

Densities of subtidal-organisms, bäsed on 24 one square metre quadrats, in the Placentia Bay collection sites, are noted in Table 20. Strongylocentrotus was by far the most abundant observed organism. In Spencer's. Cove, Littorina littorea was the second most abundant organișm. Acmaea testudinalis, Mtilus edulis, and burrowing anemones were feasonably abundant as well observed densities of crustaceans were low. Ob servations under rocks in all areas suggested a high incidence of polychàetes and ophiópholis aculeata, although such organisms were not counted.

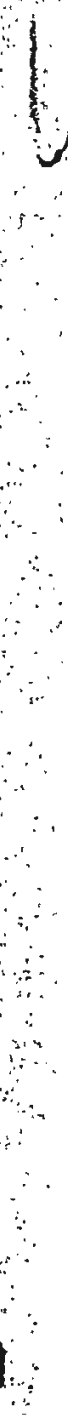


Table 20. Densities, of subtidal orgartisms in Placentia Bay (3-8* $\mathrm{m}$ depths) in late sumer and fall, 1976.

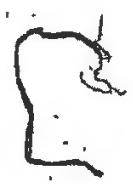

Organism

Number of individuals per square metre - mean \pm S.E. $\quad(n=24)$

Strongylocentrotus droebachiensis

Littórina 1ittorea ${ }^{2}$

Acmaea , testudinalis

Mytilus edulis

unidentified burrowing anemone

Volselia modiolus

Asterias vuigaris

Metridium senile

unidentified chiton.

Cancer irroratus

Ophiopholis aculeatab

Crangon septenspinosus

Hiate11a arctica

Hyas arareus?
$42.2 \pm 6.4$

- $15.8 \pm 4: 5$

$11.0 \pm 1.4$

$6.9+1.5$

$5: 0 \pm 1.1$

$1.9 . \pm 0.7$

$1.8 \pm 0.9$

$1.5 \pm 0.4$

$0.9 \pm 0.4$

$0.2 \pm 0.1$

$0.3 \pm 0.2$

$0.1 \pm 0.1$

$0.1 \pm 0.1$

a observed only in "Spencer's cove

b these organisms are cryptic therefore, the observed number of indivi duals per square metre is unrealistically low

Such organisins as nemerteans, polynoid polychaetes, and Nereis sp. were observed under rocks: No attenpt was made to quantify observations of any individuals not readily visible to the diver.: Dhata on

- densities of such organisms in placentia Bay were collected by Swiss and Osborne (1976): 
DiSCUSSION

Attraction to prey extracts

The attraction of lobsters, Homarus americanus, to tissue extracts of various organisms has been known for at least eighty years (Herrick; 1895; Hadiey, 1912; Ache; 1972 ; Atema and Gagósiä, 1973) Leese (1970, 1973c) observed 'barrier responses" (percentage of adult Iobsters reaching the upstrean barrier of an olfaction utrough) of 138 for tests of extracts of sea urchins and starfish, 75 for tests with mussels and clams, 848 for cod extract, and greater than 90 for tests of extracts of lobster and shrimp. The percentages of imature lobst in the present study showing food-searching behaviour are similar to the responses of adult lobsters noted by Mcleese (1970, 1973c), although his echinodem extracts were considerably less attractive than such extracts's in the present study.

Variability of response among immature lobsters was high while individual variation was considerably lower Similar high variability of population behaviour was observed in H. anericanus by Scrivener (1971) and noted in ${ }_{\text {. }}$ gamarus by Mackie and Shelton (1972) Population response variability in the present study may have been due to differences in sex, size, and natural ingestive experience of jmature lobsters prior to cap ture. The paired comparisons analysis avaided probiems with variability in analys whic allowing statements about populations of imature lobsters in general.

The food searching behaviour of inmatire jobsters, elicited to some extent by all prey extracts, appears to be a stereotyped behaviour of 
the species (McLeese, 1970;, Atema and "Engstrom, 1971; Scrivener, 1971;

Atema and Stein, 1974). Atema and Engstrom (1971) indicated three levels

- of response to food stimuli; the alert phase; the pre-feeding phase; and active feeding. The behaviour of imature Tobsters described as "foodsearching in the present study gorresponds to the pre-feeding phase described by Atema and Engstrom (1971)

A few lobsters showed merall spread and opening of the claws dưing trials with Cancer extract, indicat ing aggressive behaviour as described by Atema and Engstrom (1971), Scrivener (1971), and Hoffman et al. (1975). These displays were quickly replaced by food-searching behaviour. It is suggested that this "aggressive", behaviour is very similar in appearance to the pre feeding phase described by Atena and Engstran (1971): While there may be some difficulty in interpretation and terminology of this behavigur, it ultimately resulted in food-searching behaviour near the stimulus origin, regardless of the motivational context (hunger aggression] of the behaviour.

Because there were no appreciable differences in densities (weight) unit volume): of the extracts, diffusion to the downstream end of the trough where the Ibbsters rested was presuned similar for each extract and therefore would fot have biased the teaction times of tested lobsters Nor does it appear that the water content of tissue extracts could have influenced. the potency of stinuli to any great extent as therg was only a l5\% dif fererce in the mean war contents of the tested prey As the degree of food deprivation of individual lobsters was the same for test of each of the prey extracts the differental attraction of jouvidial 1obsters to extract must have been a a function of type or concentrations of st in the extracts themselves 
Prey preference of immature lobsters was indicated by comparịg the integrals of food-searghing response curves for the various extract trials of each lobster. Immature lobsters showed a significant preference for Cancer extract. Approximately 208 of the lobsters preferred Nytilus extract over other prey extracts. These observations indicate that olfactory preferences of imature lobsters are similar to actual food preferences of aduit lobsters : For example, Evans and Mann (1977) noted that aduit lob̆sters prefer Cancer over stropgylocentrotus, and Elner (personal communication observed a preference of adult 10 bsters for Mytilus over Strongylocentrotus:

McLeese (1970) noted in adult lobsters a high correlation between walking and feeding responses in olfaction experiments. This" is to be ex-? pected as successful feeding in nature may be dependent on movement to food. In the present study, locomotion was an important component of foodsearching behaviour during tests of preferred prey. For example, Cancer extract stimulated food-searching behayiour at the stimulus source in at least $50 \%$ of the lobsters tested, while less than $30 \%$ of the 1obsters showed food-searching behaviour at the stimulus source furing trials with each of the other prey extracts.

Exploratory rresponses by inmature lobsters in the olfaction trough were likely elicited by the introduction of the control or extract stimulating mechanoreceptors in the lobster and subsequent locomotion. With the exception of the difference between trials with controls and Strongrlocentrotis extracts, there were no significant differences in the durations of exploratory responses during the different tests, indicating that olfaction may have had little control over mediation of exploratory response 
70.

Attraction to-prey effluents

McLeese (1973c) observed barrier responses of aduit Homarus . americanus to prey effluents af Cancer, Uytilus, and Strongylocentrotus of $13 \%, 6 \%$ and $10 \%$ respectively Despite differences in test procedures, the percentages of Iobsters in the present study showing rapid approaches to the prey effluents are gimilar to the lobster barrier responses obsèrved by McLeese, Cancer effiuent apparently being more effective than the other prey effluents in eliciting the approach response.

Hirtle and Mann (1978) observed positive responses of adult lobsters to waterborne odour of intact living crabs (Carcinus maenas), sea urchins, and mussels and noted that the percentage frequency of lobster response was higher and the response time, shorter to crabs than to sea urchins or mussels: While inmature lobsters show a similar grading of responses, the percentage frequencies of food-searching responses were somewhat lower than those observed by Hirtle and Mann (1978).

The addition of control and prey effluents, regardless of their composition, to test containers with imatu lobsters consistently elicited increased antennule flicking rate and anchoring and raking of perelopods To a lesser extent, al1 prey effluents and control elicited directional movenent of antemules (pointing towards source of stimulus) and wiping of antennules and antenna Atema and engstrom (1971) sug gested that most of these behaviour types, as well as maxilliped exopdite arrest and antennal search, are characteristic of an alert phase. The alert phase is not stmulus specific It is a precirsor for all feeding and social behaviour Atema and stein (1974) sugested that the alert phase is determined by the threshold perception of the chemicar senses 
(most probably by the antennular aesthetasc hairs). However, the fact that most of the alert phise behaviour types described by Atema and Engstrom (1971) were observed after entry of seawater controls suggests a general response to entry of the stimilus rather than a speific chenoreceptor response. This general response may have been mediated by mechanoreceptors

Mechanoreceptor capabilities are present in cuticular hair-fan And hair-peg organs of H. vulgaris (gamarus) (Laverack, $1962 \mathrm{a}, \mathrm{b}$ ) and in hairs of the antehnal flagelium of the same animal (Tazakig 1977) Entry of the stimilus probably caused vibrations in the tank water which were detected by similar cuticular organs of the imnature lobsters in the present study It is possible (at legast in the laboratory) that detection of water movements is a precursor to increased antenule flicking rate, which is initiated in crustaceans to enhance detection of stimulatory food - molecules in the water (Laverack, $1964 ;$ Mcleese, 1973b; ; Price and Ache; 1977) Specifically, Srow (1973) suggested that ficking of the antennules of the hermit crab paguris alaskensis, for "example, facilitates water circulation arotind the aesthetaschairs and produces phasic sampling of dissolved chemicals in the animity's inmediate environment.

Depending on the quality of the information mediated by the an tennules, food-searching behaviour may be initiated The composition or concentration of components in the prey effluents and the motivation of the 1obsters were sufficient to elicit food-searching bejaviour as described by Atema and Engstrom (1971) The stimulatory compounds in the prey ef fluents in the present study are probably excretion products These in clude amonia and other ninhydrin positive compands Webb and Johannes, 1967 Hamen, 1968 Schoffeniels and Gilles 1970; Dal1, 1975 ; Kein Brete- 
ler, 1975; Bayne and Scullärd; 1977; Propp, 1977). The composition of prey effluents is discussed later.

McLeese $(1973 \mathrm{c})$ suggested that lobsters are not strongly attracted from a distance to intact prey The present results indicate that prey effluents have the capacity to elicit food-searching behaviour, although it is impossible to estabiosh a critical distance at which these prey effluents effectively elicit responses. In the natural envirorment, prey effluent concentrations are probably much lower than concentrations used in the present study. This consideration, as well as the complicating factors of currents, bottom roughness, and multiple sources of stimulating compounds, probabjy make the critical distance at which responses by 1ob șters are elicited very small (perhaps within centimetres) It is possible that prey effiuents may onị be effective in stimulating food-searching behaviour when the lobster is practically touching the prospective prey:

Attraction to ninhydrin-positive compounds (NPCs)

Previous studies of attractiveness of food have suggested that amino acid stimilation elicits food searching behaviour and may a component of food attraction in natural populations of marine crustaceans (Case ap Gwillian, 1961 Levandowsky and Hodgson 1965 shel ton and Mackie, 1971 ; Makie and Shelton, 1972; Mackie, 1973, Hindley, 1975) The major attractants for most of the crustaceans studied are glutainic acid, glycipe proline, and taurine (Levandowsk and Hodgson 1965 Crisp, 1967 Cartand Gurin, 1975; Al73son and Dorsett, 1977; Hartpan and Hartman 1977 Price and Ache, 1977 Johnsơn and Ache 1978 ).

Previous studies of chemoreception in the lobster Homaris amex 
icanus, have shown that ninhydrin-positive compounds are capable of exciting antennule chemoreceptors and eliciting food-searching behaviour. (McLeese, 1970; Ache, 1972; Shepheard, (1974; Mcleese et a1 1977);

The present study shows greatest attraction $(56.5 \%)$ of ininature lobsters to proline This agrees well with the results of McLeese (1970):

1. who observed a feeding response to proline in $53 \%$ of the trials with adult lobsters, and with the general observations of Shepheard (1974) for the proline compound, hydroxy L-proline McLeese et al (1977) observed a $30 \%$ response of adult lobsters to proline in an olfaction trough. Mcleese (1970) did not observe any feeding response to hydroxy L-protine, in contrast to the findings of Shepheard (1974) with respect to antennular sensitivity. Results of the present study indicate significant attraction of imnature lobsters to ammonia, arginine, Iysine, alanine, glycine, and valine Mcleese (1970) observed that most of these NRCs at relatively high concentrations elicited feeding responses in adult lobsters. In general, the findings of the present study agree well with the results neded by Mcleese: (1970) and indieate that chenosensitivity of inmature lobsters does not differ significantly from that of adult lobsters:

Various studies tindicate a threshold concentration at which crustacean's respond to NPCs on the order of $10^{-3}$ to $10^{-7}$ M (Levandowsy and Hodgson, I965; Crisp, 1967 Ache, 1972 ; Shepheard, 1974 Carr and Gurin 1975 ; Hindey, 1975 ; Allison and Dorsett 197.9, Hartuan and Hartuan, 1971) Fuzéssery and Childress (1975) ầd Price and Ache (1977) observed diectrophysiological responses of antennule nerve fibres of marine orustaceans to

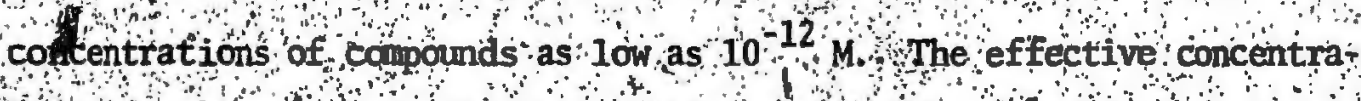
tions of NCs the present study ranged from 1 io $x^{-1}$ at the target to

W temal concentration of $x$ o assung tota dissolution of the 
NPC in the lobster tank. All NPCs were theoreticalily detectable within. the limits of these concentrations.

It was interesting to note that the most attractive $\mathrm{NPC}$, proline, is the most soluble of all NPCs tested (windholz et al 1976) " Other NPCs which were significantly attractive to jumature lobsters relative to control trials are also yery soluble. Despite the greter attractiveness of very soluble NPCs, there was no apparent correlation between percentage frequency of target captures and the mean time to target capture This indicates that solubility of NPCs did not sigmificantly affect the rate of diffusion in the lobster tank and the time to response by lobsters ip Solubility may be an important "factor at the chemoreceptor surface the more soluble NCS perhaps being more easily detected and, thus, more at actave. Most of the attractive NACs; with the exception of arginine and lysine, are relatively smait mbleculestompared to those NPCs which are not attractive. Molecular size and eonfigurqtion may be other important factors affecting attractiveness at the chemoreceptor surface Lindstedt (1971) suggested that the $\left(\mathrm{OH}_{3}\right)-\mathrm{N}$ moiety of such compounds as trimethyl amine oxide and betaine is the active part of the molecule el iciting feedjrig responses in crustaceans. Case (1964); in his studies bf dactyl chenoreceptors of Cancer, observed that increasing the size of the molecule re-. duces stimulatory capacity and that maximai stimulatory capacity occurs in straight-chain anino acids with three to fipe carbon atoms Hartman and Harman (1927) observed in the porcelain crab, Petrolisthes cinctipes that amino acid stimili become Iess effective in irstiating feeding behaviour as the chain 1ength is increased The present findings are compatible with those of the studies above

The four most attractive NPCs in the present study (proline am 
monia, arginine, and lysine), in their ionized form at normal $\mathrm{pH}$, are charactérised by nitrogen in the $\mathrm{R}$ group (Lehninger, i.975) : The last three NPCs are positively charged in their ionized states. The next three most attractive NPCs (alanine, glycine, and valine) are characterised by small R groups, $A 11$ the remaining relatively unat tractive NPCs are characterised by large R groups. Those NPCs with large Rroups containing nitrogen are uncharged, It appears that NPCs with small $R$ groups or $R$ groups containing charged nitrogen are potentially attractive to inmature lobsters.

Analysis of NPCs in prey tissue extracts and effluents

The results of analysis of NPCs in tissue extracts indicate a relatively consistent pattern of NPC composition in marine invertebrates as noted in previous studies (see Awapara, 1962; Schoffeniels and Gilles, 1970 for reviews). Glycine generaliy makes the greatest contribution to the free NPC pool, with relatively large contributions from alanime, ammonia, proline, and taurine

Taxonomicaliy rélated species appear to have similar NPC canositions : For example, the echinoderms Asterias, Ophiopholis, and Strongylocentrotus ali show a high concentration of glycine and a very low concentration of proline Ophiopholis differs slightly with a high concen tration of taurine relative to other NPCs.

Results of the present study agree with those of other studies of echinoderns (Kittredge et al, 1962), littorinid snails (Kittredge 11, 1962), Mytilus edui is (Wachtendonk and Kappler, 1977), Nereis virens (Ackermann, 1955 cited in Awapara, 1962) and decapod crastaceans (Camien et al a 1951 , Carr, 1967 Schoffeniels and Gilies 1970 Siebers et al 
1972; 'Weber and van Marrew̌ijk, „1972; Torres, 1973; Roesijadi 'et al... 1976; Richard; 1977; Johnson and Áche, 1978).

There were few significant differences between individual NPC concentrations of the tissue extracts among species However, the significantly greater concentrations of glutaric acid, glutamine, proline and - taurine in Cancer extract compared to concentrations in the extracts of mast echinoderm species may refiect fundamental phylogenetic differences in NPC composition. The same may be true for the high tota1 NPC concentrations of crustacean and polychaete tissues compared to those of echinoderms. For example, Schoffeniels and Gilles (1970) observed that the arthropods are one invertebrate phylum in which very high amiño acid concentrations are found. High total NPC concentrations in tissues of crustaceans have alșo beefobserved by Camien ent al: (1951), Weber and van Marrewijk (1972), Torres (1973), and Roesijadi et, al. (1976).

Schoffeniels and Gilles (1970) commented that considerable variations in NPC composition of crustaceans exist in the same tissue from different species and different tissues from the same species Kittredge et al (962) noted that it is necessary to consider several criteria such as ecological infiuences developmental state, and sampling of individual tissues in comparative biochemistry It is possible that ali of the above factors may have influenced to some extent the NPC compositions of individual species in the present study Despite this and the variability inherent in smail sanples, the total NPC concentrations and NPC compositions of tissue extracts appear to be phylogenetically distrot

The perceptage contribution of anmonia to the total free NPC pool of tissue extracts ranged from $59 \%$ in Asterias to $22.8 \%$ in Nereis sp. The concentration of amonia in the present investigation may be nore

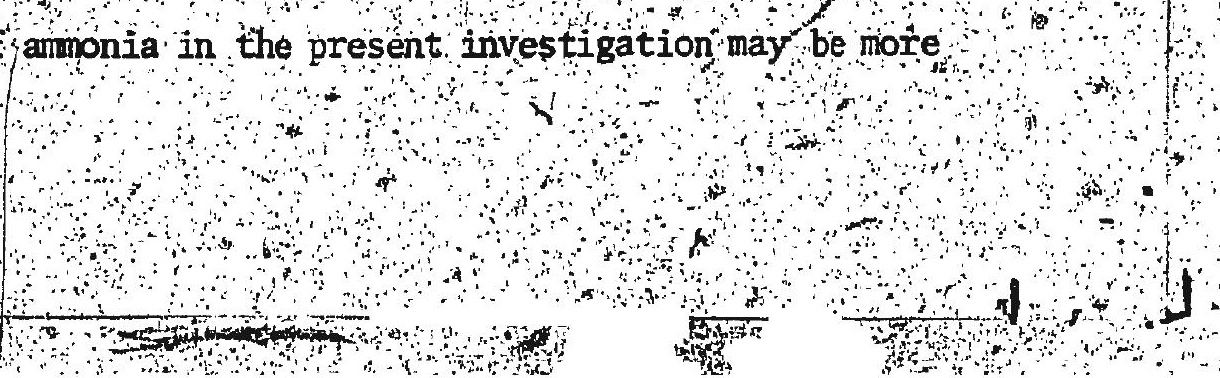


77.

apparent than real as amonia could be produced by spontaneous release from protein prior to deproteinization and the breakdown of glutamine

(Meister 1965 ; Patterson, 1972). The absolute concentration of glutame remains uncertain because of this consideration. The extremely hiog and variable levels of urea in tissue extracts of most of the species tested remain unexplapined.

Free NPCs in invertebrates are generally implicated in osmorégulation" (Awapara, 1962; Schoffeniels and Gilles, 1970). Catabolisin of proteins results in many NPCs in a free state. "Different concentrations of NPCs could possibly be explained by different rates of active proteoIysis (Awapara, 1962): Several stiudies have suggested that amino acids may be used in the process of energy production (Schoffeniels and Gilles," 1970) NPCs such as amino acids, as well as amonia and urea are capable of being excreted by molluscs, polychaetes, crustaceans, and echinoderms (Meglitsch, 1972) and may be detectable in the vicinity of individual organisins.

The amino acid analyzer used in the present study is capabie of detecting NP concentrations as low as 2 nanomos per mo Analysis of seawater allowed to stand for eight hours showed only trace amounts (i.e less than 2 nanomoles per mi) of amponia. No other NPCs were detected Other NPCs, however, certainly exist jawa ter at very low concentrations. Daumas (1976) observed average concentrations of total dissolved anino acids varying between 0.9 and 1 nanónoles per ml of coastal seawater in the Guf of Marsejle Total amino acid concentrations in other areas are generaliy less than one nanomole per ml (see Daumas, 1976 for review). Background levels of NPCs are mainly composéd of gycine, setrie, anine threponine and valine (Riley and Segar 1970; Daupgs 1976) 
The sources of NPCs in seawater are generally considered to be bacterial degradation of particulate proteins and excretion by organisms (Webb and Johames, 1967 Daumas 1976). The fact that amonia was the only NPC detected in the seawater control ifmplies that animian is the most abundant NPC in seawater, al others being below the limit of detection.

All organisms in the present study showed excretion of anonia, concentrations in the closed containers after eight hours ranging from 42 nanomoles per ml in the Mytilus container to 199 nariomoles per mi in the Nèreis container. Only Asterias showed excretion of detectable amounts of other NPCs, It is conceivable that the other organisms excreted NPCs other than ammonia at levels below the limts of detection. For example; Webb and Johannes (1967) sobserved excretion of NPCs in zooplankton and noted that glycine comprised an average of $31.7 \%$ of the tota1 NPC release. Alarine and taurine were conspicuous as well "However, most of the in vertebrates in the present study, and related species, excrete nitrogen mañly in the form of anmonia (Hamen, 1968; Schoffeniels and Gilles $1970 ;$ Bayne and Scullard, 1977; Propp 1977) which explains why anly amonia was detected in the effiuent water of most of the organisms studied.

The contribution of amionia to the total excreted nitrogen is variable depending on season and habitat (Bayne and Scullard, 1977) and may reflect the protein content of the diet (Handent 1968), especially as the prime sounce of amonia is demination of amino acids after protein catabolism (Schoffeniels and Gilies, 1970)

In thits regard, it was thteresting to note that the greatest quantities of excreted ammonia were produce by the carnivores Asterias, Nereis, and Cancer The high absolute quant ties of ammia in effluent relative to that produced by the omivores and herbivores ophiopholis, Strongyocentrotus, Littorina and Mtilus) may refect the higher protein Stron 
Content in the diet of the camivores.

Pdsssive diffusion or leakage of NPCs, as well as true excretion, may occur in Asterias, the effluent of which shows relatively high concentrations of glycine and anmonia, and lower concentrations of alanine, his tidine, and 1ysine Glycine and ammonia are the most concentrated NPCs in Asterias tissue extract (see Table $9, \mathrm{p}, 39$ ). Alanine and histidine

- are reasonably concentrated as we $11 \%$ The reason why Asterias produces detectable amounts of NPCs other than anmoria and the other organisms do not is not readily explained.

Controlled prey selection

Consuntion efficiency in the present study is a function of the attack rate and the presumed consumption rate of inmature lobsters. Standard errors for consumption efficiencies were relatively small, indicating that the variation of the prey-population in experimental tanks probably had 1ittle influence on the attack and consumption rates Reddin (1973) did observe some variation in the attack rates of lobsters offered various combinations of prey, al though this was usily only the case when one of the two prey species offered was relatively unpalatable. Breen (1974) noted only a few differences in attack rates of lobsters offered tw types of prey. He observed that sea urchins and starfish were eaten at a jower rate than usual when crabs were present, ard when sea urchins and starfish were offered together the latter were eaten at a higher rate than usua A relatively large sämple size in thé present study and offerings that in ciuded generally palatabie species minimised variation in data due to dlf ferent combinations of prey. 
80.

Previous studies of lobster prey selection indicated a general preference for crustaceans over other prey species (Breen, 1974 ;-Evans and Mann 1977) Evans and Mann (1977)-concluded that lobsters feed selective1y and that preference for crabs (cancer jrroratus) over sea urchins re flects energetic and nutritional advantages of the crustacean diet over the urchin diet. Lobster preyr selection studies by Reddin (1973) involved a greater number of species than the studies noted above. Reddin tested selection of prey by lobsters two species at a time His data concerning selection of Strongy locentrotuis and Cancer indicated an equal preference for both species. This differs considerably from the observations of Evans and Manin (1977) who showed that lobsters selected Cancer five times as much as Strongylocentrotus when the two species were offered in 1 i ratios.

In terms of Strongylocentrotus and cancer, results of the present study are intermediate between those of Reddin (1973) and Evans and Mann (1977) with attack frequency for Cancer approximately twice that for strong ilocentrotus. The mean percentage frequency of selection of Cancer in five of Reddin experimental situations was 650 , which agrees well with results, of the present study, although the other prey species offered in Reddin's study differed somewhat, inciuding Mytilus, Buccinum, Strongylocentrotus, Hyas, and pagurus other mean values were calculated from Reddin s data Mean percentage frequency of selection of Mytilus was 73s considerably higher than the attack frequency mytilus the present study The value for Strongylocentrotus was 50.39 , again higher than the attack frequency for Strongylocentrotus in the present study These latter two high attack rates lin Reddis study are probably a finction of relatively unpalatable prey being offered in combination with Mytilus and strongylocentrotus Elner (personal eommication) found that lobsters of various (a) 
sizes showed a $43: 1$ preference for mussels over sea urchins when of fered both prey. Only 399 of the lobsters would feed on sea urchins in the first place during six-day feeding trials. In the present study, 32.48 of the imature lobsters fed on sea urchins when of fered various prey.

For Asterias, Reddin (1973) found that the mean percentage fre

quency of selection was $10.3 \%$, considerably lower than the at tack frequency for Asterias in the present study: There are no comparable published results for selection of ghiopholis, Neréis, and Harmothoe, although Reddin (1973) suggested that ophiopholis and Nereis are probabiy only in cidentally consumed by adult Honaris americanus. Reddin claimed that it Was difficưft for adult lobsters to obtain polychaetes In the present study, polychaetes were obvious ly accessible to the small lobsters tested

The presuned rate of consumption for imature lobsters in the

present study was $4.69 \%$ of 10 bs ter weight during 24 -hour tes ts this agrees fairly well with studies of adult lobsters (Hinnelman and Steele, 1971; Breen, 1974 ; Evans, 1976) and with the observations in this study of gut contents comprising 1.38 to 1.70 of inmature lopster weight ore day after feeding: Mcleese $(1972 a, b)$ and McBuney and Wilder $(1973)$ detenined that a feeding rate of 68 of lobster weight per, week fon a diet of cod, liver, and squid) was capable of sustaining healthy growth in adult iobsters:

It is recognised that soge unkrown proportion of food attributed to consiauption by inhature lobsters may have been lost during feeding in the form of body fluids and smal1 particies The real consumption rate of immature lobsters may, therefore have been lower than 4.698 of lobster wht per trial Dagg (1974) suggested that a predatoits appetite affects the number of large prey particles that are discarded If eating motivation is low or if prey density is high "the predator can afford to eat 
less efficiently.

At. least four factors probably influenced the attalck rates and consumption efficiencies of immature lobsters offered various prey. These. are prey size and morphology, behaviour of prey, and innate selectivity : of prey by lobsters related to calorific and nutritional value of the various prey species. The latter is discussed later. With the exception of Littorina which possessed.a thick she11, the smaller species were more frequently attacked than the larger species, and consumption efficiencies were highest for the smallest prey. Small prey may be attractive to inmature lobstedrs because of the relative ease of capture and consumption of individuals compared to the larger species. Similar studies of various inyertebrates indicate that prey size is a major limiting factor in predation success and that predator morphology and energy maximisation in feeding determine the optinal prey. size (Ebling et a1., 1964; Maintz et a1. 1965; Himelman and Steele 1971; Hamilton, 1976; Holling et al " 1976; Paine, 19,76; Elngr and Hughes, 1978; Elner and Jamieson, 1979; Pol10ck, 1979). The results of Table.13 (p. 45) imply that the overali range of sizes of individuals of Ophiơholis, Nereis, and Harmothoe did not influence the attack rates as there were no significant differences between the sizes of ignored and attacked indịviduals. In nature, because of the low upper limit of size, probably all individuals of the above three species would be susceptible to predation by lobsters of a size used in the present study.

There was never evidence of attack of Littorina by imature liobsters. The shell of Littorina littorea is very thick and the sizes of individuals in the present study may have precluded"attack,

With Asterias, Strongylocentrotus, and Mytilus, it was apparent that the -large sizes of several individuals relative to the lobster may. have occasionally precludeả attack. "In nature, some Asterias individuals. 
máy be too'large for attack by the chelae of a small lobstor, although it is hard to imagine that even a small lobster could not inflict some damage to a large starfish, considering its soft morphology and slow movements. Fow example', Aldrich (1976) suggested that Asterias forbesi is"a cooperative prey for Libinia emarginata, which attacks sizes of Asterias out of proportion to its chela size. In his observations, he noted that autotomy of a starfish arm accommodated this out-of-proportion predation. Elner (personal communication) observed size selectivity of lobsters feeding on sea urchins and noted that smaller lobsters feed on smaller urchins. Elner. and Jamieson (1979) noted size selectivity of lobsters when feeding on sçallops. Large Mytilus and Strongylocentrotus can avoid predation by exceeding the extent of chela spread of tminature lobsters. The same is probably true for large crabs.

Reddin (1973) stated that the largest sea urchin eaten in his experiments with adult lobsters was $16: 7 \frac{6}{10}$ of lobter weight. "This is considerably jarger than the mean size of attacked sea urchins in the present. study. Reddin collected the data from lobsters which were offered only sea urchins. In the absence of a choice, lobsters may have attacked greater than optimally-sized urchins to avoid starvation. Reddin (1973) ob:served that lobsters will attack large sea urchins through the Aristotle's lantern if the claws are ineffective in imibbilising the prey. He also noted that the largest attacked crab was 6.88 . of lobster weight, which is considerabiy less than the mean size of attacked crabs in the present study. The possible reason for this disparity is that Reddin used large lobsters for Cancer consimption experiments such that even the largest attainable size of an individual crab would rarely have exceeded $6 \%-7 \%$ of the mass of the lobster's used in his study. 
It appears that small crabs may effectively elude predation as

we11. In the experimental situation, smaller crabs may have been successful in hiding beneath the rocks provided or were' more agile than larger crabs in their escape response. In any case, because size of prey may have been a limiting factor in predation success, percentage frequencies of attack presented in Table 10 (p. 41j are probably lower than would be the case with optimally-sized prey. On the other hand, the constrained movements of prey in the tanks probably enhanced lobster-prey encounters such that percentage frequencies of attack of prey in the laboratory do not necessarily reflect absolute attack rates in the natural environment. Uneaten portions of Mftilus dilmost exclusively consisted of tissure-free fragments of shells which conprised, on average, 40.70 of the total wet weight of the attacked individual. Measurements of the contribution of shell to the wet weight of live Mytilus ranged from $29.8 \%$ to 35.68 . Reddin (1973) observed that little Mytilus shell was consumed by aduit lobsters. These observations suggest that lobsters can efficiently separate the tissue and shell of its prey. However, gut analysis revealed that immature lobsters consume small but conspicuous amounts of shell and byssus threads when feeding on Mytilus. Pollock (1979) observed the same thing in the rock lobster, Jasus lalandii. Reddin (1973) inferred from remains of seg urchins after lobster feeding that little test was consuned. However, Elner (personal commication) observed that lobsters of various sizes ingest test of sea urchins while feeding on that prey. On average, approximately $50 \%$ of captured sea urchins were consumed by imnature lobsters, gut arialysis indicating a significant ingestion of urchin tẹt.

1. The mean wet weight of Cancer individuals offered to immature. lobsters was approximately three times that of the: next largest prey avai1:- 
abie. As a consequence, percentagè conșumption of crabs was relatively low. Despite this, the mean amount of crab.consumed per attack was highest, almost twice the amount consumed of most of the other species, in: dicating relatively sustained feeding of lobsters on Cancer compared to feeding on the other species.

Qut content analysis

Gut contents of adult Homarus americanus have been examined by several people Some results of their studies are sumarised in Table 21. Data from the present study are similar to results of previous studies, taking into account possible differences in prey availability due to location and bottom type The percentage of llimature jobster guts with crab remains is intermediate between values given for adul tobsters in other locations in Newfoundland by Squires (1970) and Ennis (1973) The relative incidence of remains of missels and sea urchins in imature lobster guts, on the other hand, is considerably higher thar such values for adult lobsters in other locations in Newfoundand. This may refiect a greater importance of such prey in the diet of immature lobsters or a difference in their availability. The adult lobsters in the study by Squires (1970) were taken by camnercial fishermen from depths of water down to 18 metres. At these depths, abundance of sea urchins and mussels is probably. less than in the shallow talus areas observed in the present stiudy where food is abundant (Himelman; 1969; Fletcher et al, 1974l on the other hand, Scarratt (personal communcation) observed that sea urchin remains were more comon in the guts of smaller lobsters compared to large lobsters in the Northumberland Strait. In Newfoundiand, at any one point in time, 
(a)

Table 21. Sumiary of gut content analyses of ajdult lobsters (H. americanus):

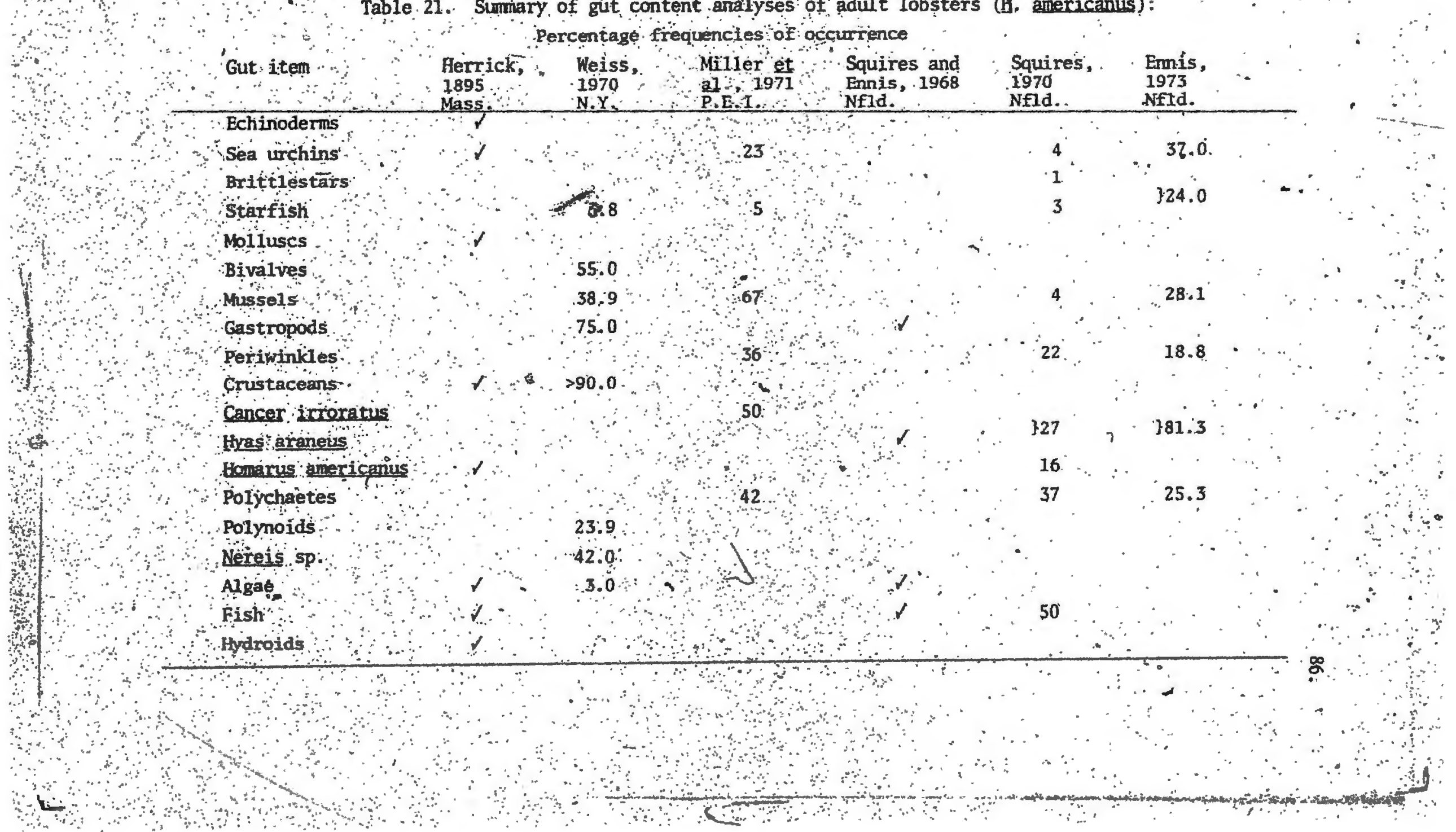


imature lobsters are probably more numerous than adults bẹcause of the cimulative effect of natural mortality, and, for lobsters larger than the minimum legal carapace length of 81 mm; the high rate of exploitation of the fishery (Enis, 1974) o. Size selectivity of prey may ceduce the degree of food tequirement overiap between small and large lobsters. "However; the high level of conpecific food competition which exist between inmature lobsters may result in a singler percentage of the imnature lobster population, compared to that of the adurt popilation; feeding on preferred prey of àn optimal size such as cancer, and a greater percentage relying or sea urchins and mussers as the gut chntent data suggest.

The incidence of polychates in guts of inmature jobsters is very sinilar to values obtained previous studies (Squires ig7o Heiss, 1970 Milier et al 1971 , Envis lo73) For both imature and advit lob sters the frequency of Astexias in guts is relatively 1ow Brittiestars may form more important part of the diet of imature lobster than adult 10bsters, as previous studies show a fow incidence ophiopholis (Squires 1970 ; Miller et al : 1971; Ennis 1973): Altematively, the difference between inmature and adul lobsters the incidence of ophopholis in the guts may reflect differences in the availability of this prey o... Incidence of periwink in the guts of pmature Iobsters is very similar to values recorded for adult lobsters from various Iocations (squires 1970 Miller ef al 1971 Ennis 1973$)$

In the present study cancer occurred in greater percentage of guts examined in late sumer than in early sumer and fall Scarratt (personal conmuincation observed that crabs are more important in the diet of lobsters in the Northmberland Strait at the end of simer compared to other times of the year when samples were taken. The seasonality of crab 
88.

incidence in inmature lobster gyts may have been due the increased vulnerabijity of crabs during their moulting period. Weiss (1970) noted that increased ingestion of Cancer spp. in New York coincided with moulting of those animals.

The higher incidence of lobster shell in late August and early September coincided with the lobster moulting period and may indicate consumption of cast exuviae (Herrick, 1895; Reddin, 1973) A greater incidence of mollusc shells was noted in post-moult immature lobsters than in lobsters taken at times other than the moulting period similar feeding habits in aduit lobsters were recorded by Herrick (1895), Weișs (1970); and Reddin (1973) It has been suggested that this shift to a calcium-rich diet aids she h1 hardening after mout ting.

The apparen feeding rate of ingature lobsters based on estimates of gut fullness changed little throughout the study period, with oniy a slight decrease by October/November these results are very similar to those of Ennis (1973) for aduit mald lobsters. The feeding level coincided roughly with seawater temperature unti1 the end of September. "Feeding rate appears to remain fairly high after that period and may indicate the need for food for physiological recovery after moulting to late sumer (Ennis, 1973) Scarratt (personal conmunication) observed that gut contents comprised approximately 1 to to 2.5 of lobster weight values for jumature lobsters in the present study are simitar

The high incidence of polychaetes in inmature lobster guts in Iate stmer may indicate increased availability of these prey at this time of year pettibone (1963) stated that Nereis virens for example swarms during the reproductive season in New England from March to August Weiss (1970) noted that nereids in Long Is Iand Sound swarmed in Iate spring and 
that incidence of nereids in lobster guts coincided with this swarming period. Nearily ail nereid polychaetes die after spawning (Pettibone, 1963) and may be more accessible to lobsters when in degenerated condition. Apart from the spawning period, polychaetes are probably available to lobsters foraging at night, as both polynoids and nereids are active night predators; especially in mussel beds (Pettibone, 1963). .

Figure 15 elaborates the ways in whitch individual prey species. may contribute to the immature lobster population diet and permits speculation about the mode of feeding of individual lobsters. It is an adaptation of the graphic portrayal of gut content analysis of Burukovskiy and Froyerman (1974) Point A indicates the theoretical situation of a singleprey diet, assiming that detection of hard parts in the imature lobster gut is possible within a period longer than the tolerable interfeeding period Both the percentage frequency of occurrence of $A$ in guts of the lobster population and the percentage conth bution to the volume of gut items when A occurs are 100\%, Theoretical species $B$ and $\mathrm{C}$ are presumedto have equal importance (in terms of volume, not calorific or nutrịtional value) in the inmature lobster population diet and are equidistant from $A$. A greater proportion of the theoretical population feeds on $B$; but when it does so, B forms a small proportion af the total volume of gut items. Species $C$ is opposite. It is not consumed by the population as frequently as species $B$, but when consumed, large quantities are ingested relative to the volume of other items in the gutt.

In terms of the overala volume of food consumed by jumature lobsters, it appears that Cancer is the most important prey Cancer occurs relatively frequently in inmature lobster guts and contributes a relatively large proportion to the total volume of gut contents, compared to other 


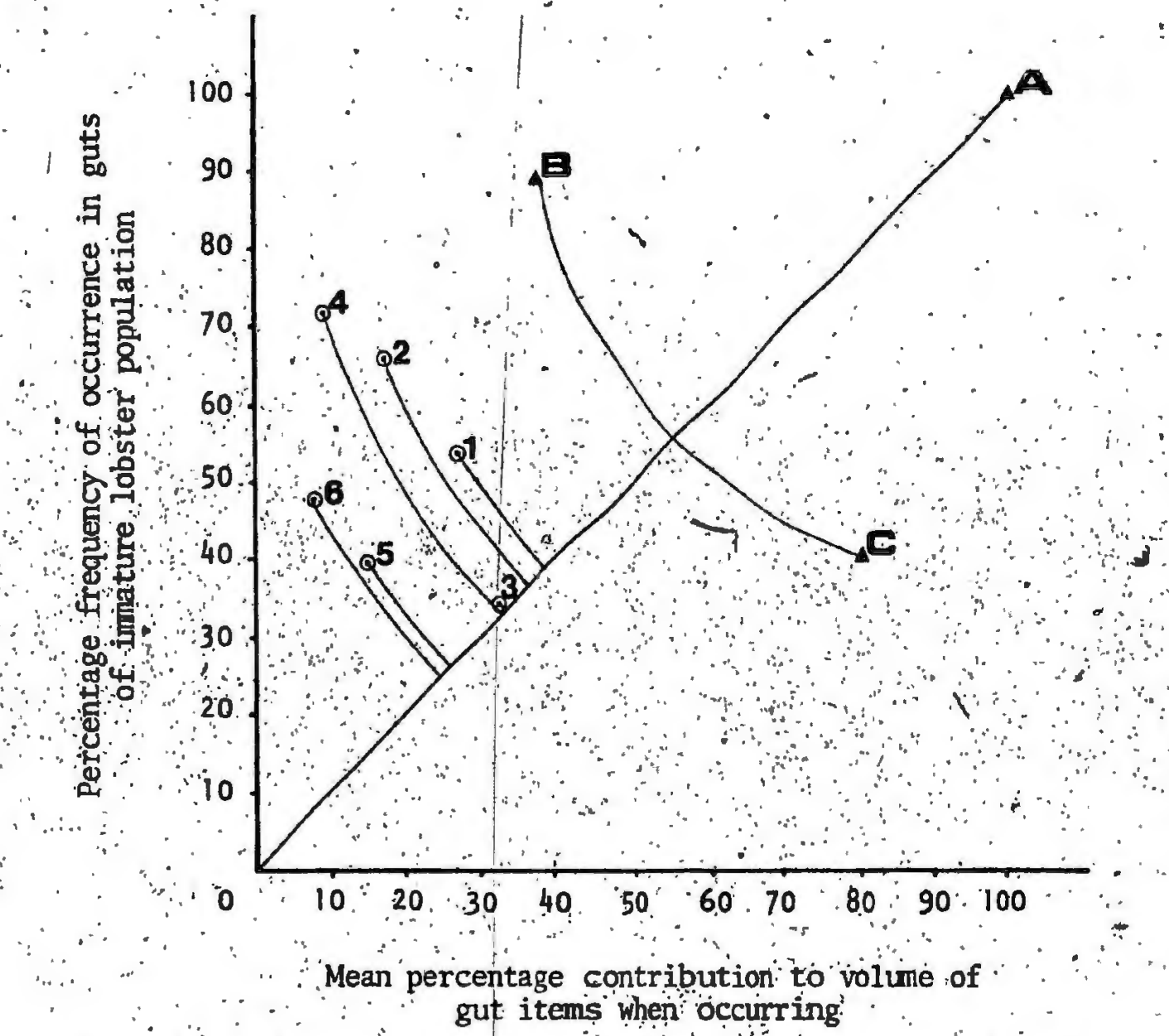

-Figure 15. Relative volume contributions of prey species to the innature lobster (H. americanus) population diet : (see explanation jn $\%$

$$
\begin{aligned}
& \text { text, p, 89) } \\
& 1 \text { - Cancer } \\
& 3 \text { Optilus } \\
& 4=\frac{\text { Ophiopholis }}{5 \text { Nerengylocentrotus }} \\
& 6-\text { polynoids }
\end{aligned}
$$


items in the gut. This may' indicate that Cancer is preferred by imature lobsters over other species: An hindividual lobster eats more of cancer during a single feeding than it does of most other species (as shown in the controlled prey selection experiment); either because more crab is available (the crab is larger than other species), or more hard parts are ingested at a single feeding than other species (see APPEDIX E) In either case, it appears that the lobster feeds uninterrupted to satiation, ignoring other prey species which may be available Mytilus is preferred second to Cancer by this reasoning. It occurs more frequently than Cancer in lobster guts, but contribittes a smaller propontion to the total volume of gut contents Strongylocentrotus is preferred less than either cancer or Mytilus, being frequentiy ingested but contributing little to the total volume of gut contents It is interesting that ophopholis, arother echino derm is equally as important as strongylocentrotus, jut reflects a different lobster feeding strategy: It occurs much less frequentiy in lobster guts than urchins, but when it does; contributes a large proportion to the total volume of gut contents. This may indicate that Ophiopholis is only, consumed in extreme situations (when the gut is virtualiy empty) such that Ophiopholis contributes a large portion to the total volume of gut contents. on the other hand, the values may indicate the mode of consumption. Ingestion of hard parts of Qphiopholis is inevitable (as confirmed by the controlled prey selection experiment) considering the morphology of brittlestars and their size. 'Searchin consumption may involve less ingestion of hard parts as the soft tissue is more easily separated from the test. Polynoids and Nereis sp. are almost equally preferred. They are less frequently consumed than the other prey species and contribute a fairly small portion to the total volume of gut contents. The smali size 
of these polychaetes relative to the other prey spectes is probably the -reason for these values conisdering that ingegtion of polychaetes is vir tually 100\% of the prey individual when does ocur.

Consideration of the density of prey: in Placentia Bay further elucidates the degree of preference of imature lobsters for certain. species: While Figure 15 shows a certain preference of immature lobsters for species in terms of voliume contributions to total gut contents, it is not directiy related to accessibility of those species in the natural environment.

1 The present study shows a numerical dominance of sea urchins over mussels and crabs in the shallow subtidal zone of Placentia Bay Density of mussels is $16 \%$ that of urchins and crab density is approxinately 0.58 that of urchin density These data are in general agreenent with other studies in eastern Canada (Himelman, 1969 ; Miller et al 1971 Scarratt and lowe, 1972; Fletcher et al., 1974; Swiss and Osborne, 1976 ; DrumondDavis, 1978, Wharton, personal conmmication) Swiss and osborne (1976) conducted subtidal sampling in placentia Bay around the Came By Chance re:finery location: Their subtidal transects 5,6 , and 8 were very close to collection sites in the present investigation. They noted that polychaete worns were the dominant subtidal organisms (in terms of numbers) Mean abuidance of polynoids ranged from 18.6 to 78.5 per squa re metre for Harmothoe jombricata and was approximately 22.1 per square metre for Lepidonotus squamatus . Mean abundance of Nereis pelagicä ranged from 23.1 to 35.6 per square metre. Mean abundance of ophiopholis ranged from 43,4 to 59.6 per square metre. These prey density data are incorporated into electivity indices discussed below.

Ivlev (1961); in his experinental study of the feeding ecology of fish, suggested that the fundamental concepts of selective feeding include

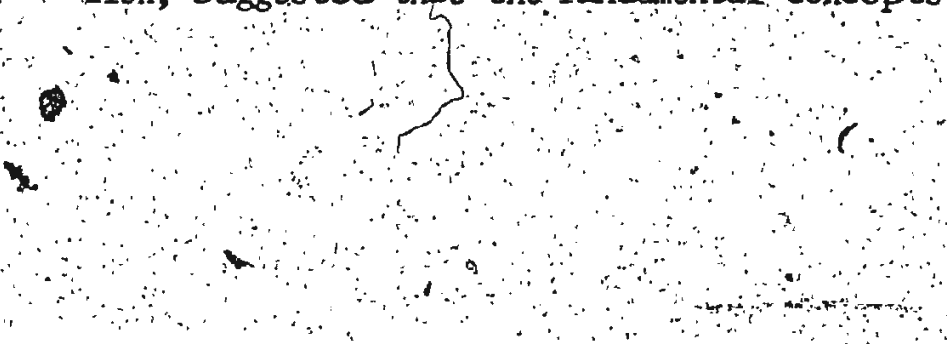


93.

the accessibility of an iten of food and a degree of preference for it. He stated that the degree of success in hunting must be proportional to' the degree of concentration of prey to accomodate the variables wicl infiuence selection of food, IvIev suggested use of an lelectivity! index $E=\left(x_{i}-p_{i}\right) /\left(x_{i}+p_{i}\right)$

where:

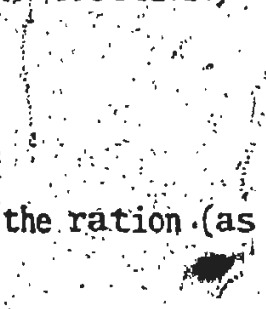

a percentage of the whole ration)

$\mathrm{p}_{1}=$ relative value of the same ingredient in the complex of the enviroment

Chesson (1978) and Cock (1978) observed that cons ideration of a value of Ivlev's E in isolation can be misleading as it suggests that a predator's behaviour towards a single prey type is unchanged, regardiess of the percentage contribution that prey makes to the total available food. Preference values calculated using this index for different prey denisities are not directly comparable cock $(1978)$, however, pointed out that Ivlev's index, unlike others (see Cock, 1978 for review), does have a more functional scale of preference (it is finite) which is more sensitive to slight preference, and the index does have the advantage that more than two prey types man be included. Ivlev's electivity index was used on data "from the ( ) present study, because of its simplicity and because there are no comparisons of $\mathrm{E}$ among experiments with varied prey densities It provides a very useful indication of selective predation in immature lobsters.

Ivlev's electivity index was calculated for the natural situation by considering accessibility of prey in terms of their numbers (Table 22) and their biomass (Table 23) The paraneter $p_{1}$ was based on values fram the present study and means of values reported by Swiss and Osborne (1976) 
Table 22 Electivity index based on natural avalability (-in terms of numbers of prey species and the per centage of imature lobster (H americanus) gits Yh which those species were dominant.

Ophophols

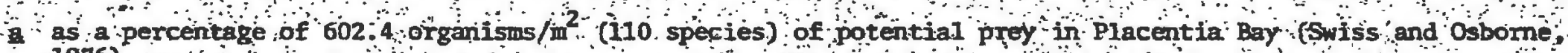
1976)

b equivalont to percentage of inmature 1obster guts in which dominant (leeding proportions (Peterson and

غ : mean of values recorded by swişs and ósborne (1976) .

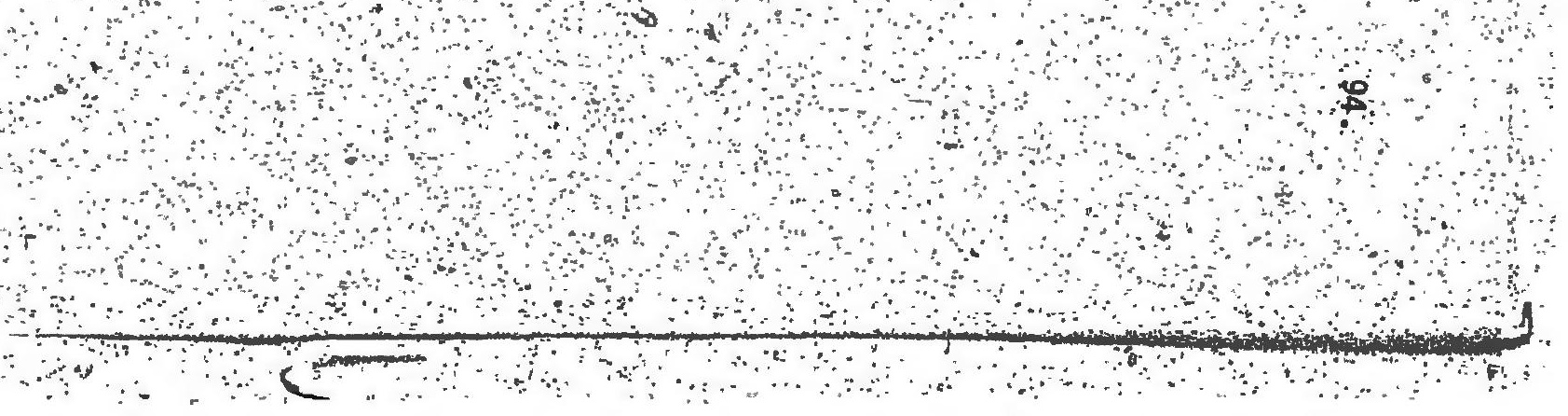



for species not counted in the lobster collection areas. In the case considering accessibility of prey in terms of their numbers, the parameter $r_{i}$ was expressed in terms of the percentage of guts in which a species was dominant, implying that the last meal was the dominant item in the gut (see APPENDIX E) and that if no preference were exhibited by lobsters, E would be 0 because of the equality of $r_{i}$ and $p_{i}$. If dominance in the gut can be considered attributable to the last meal, this variable is equivalent to the proportion of all individuals found feeding on a given prey type ("feeding proportion") (Peterson and Bradley, 1978), and is a reasonable measure of $r_{i}$. The parameter $r_{i}$ in the case considering accessibifity of prey in terms of their biomass was based on the relative contributions of prey species to the total volưne of the inmature lobster diet, considered equivalent to. weight contributions if there are negligible differences in specific gravities of prex?

Application of Ivlev's electivity index to the gut content data indleates a high degree of selectivity for Cancer and Mytilus (Tables 22 and 23). These two species comprise only a small percentage of the available prey species population in terms of numbers and biomass. Nereis sp., as well, is apparently selected out of proportion to its natural availability in terms of both numbers and biomass. Brittlestars are selected by immature lobsters more frequently than would be the case if predation occurred randomly, but do not comprise a disproportionate weight of the total volune of gut contents (Table 23): The negative indices suggest that most of the more numerous prey species are frequently ignored or not encoumtered by lobsters at a rate proportional to their abundance. They

- may only be consumed by immature lobsters when the more preferred prey species are not available. While the electivity indices are based on -several estimates, rather than absolute values, they do provide a useful comparison of gut content data and natural relative abundance of prey. 
Considerations of immature lobster feeding behaviour in terms of optimal foraging

It is important to consider the results of the present study in terms of various discussions of feeding strategies and optimal foraging (see Schoener, 1971; Pyke et al., 1977 for reviews). Most considerations of optimal feeding are of a theoretical nature, concerned with development of foraging models with predictive capabilites (Enlen, 1966; Schoener, 1969; Rapport and Turner, 1970; Rapport, 1971; Marten, 1973; Katz, 1974; Nakamura, 1974; Pulliam, 1974, 1975; Griffiths, 1975; Covich, 1976; Norberg, 1977; Hughes, 1979; . Stenseth and Hansson, 1979) : A few studies of actual feeding strategies of arthropod predators, fish, and echinioderm foragers exist as well (Werner and Ha11, 1974; Charnov, 1976; Vadas; 1977; Cook and Cockre11, 1978; Elner and Hughes, 1978). Several studies are concerned with switching behaviour and fuctional responses of predators to prey density (Holling, 1965, 1966; Murdodh, 1969, 1973; Oaten and Murdoch, 1975; Cornel1, 1976).

One of the main premises of optimal foraging theories is energy maximisation whereby a predator chooses its diet to maximise net energy intake per unit foraging time. An alternative premise, not exclusive of the latter, is mintimisation of time in the foraging process. The parameters which are integrai to theoriess of energy maximisation are searching time, handling time, and calorific value of the prey. Generally; the theoretical optimal diets are determined by beginning with the highest value of the ratios of food value to haridling time and then adding food types to the diet in rank order. The optimal diet includes all itens for. which the ratio above is positive. 
Several factors are important. to the development of optimal

foraging theories. One of the assumptions of feeding 'models is that predators forage efficiently, yet this requires an ability of the predator to assess energy value of individual food itens. Enlen and Emlen (1975) suggested that predators are not capable of this perfect decision making. Charnov (1976) and Norberg (1977), on the other hand, suggested that energy efficiency is only one ultimate factor in feeding strategy, and Marten (1973) and Westoby (1978) suggested that sampling of food may be an important component of foraging behaviour such that variety is maintained even when food is superabundant. Maintenance of food variety may be especially. important when maximm fitness of the predator is defined not only by calories but also by other nutrient factors as well (Pulliam, 1974): One of the manifestations of nutrient constraints in available diets is establishment af partial preferences whereby some prey types are consumed on some encounters but not all encounters (Pulliam, 197.5). Finally, one of the main suppositions with considerable empirical proof is that predator selectivity of diet decreases as the total abundance of food decreases (Hol ling, 1966; Werner and Hal1, 1974; Charnov, 1976; Vadas., 1977; Cook and Cockrell, 1978; Elner and Hughes, 1978).

Elner and thughes (1978) explored optịmal foraging in the shore $c r a b$, Carcinus maenas; incorporating the concept of a finite recognition time as the predator evaluates the prey by chemical and tactile clues. They suggested that, 'because the crabs are not visual hunters, they cannot scan large áreas to estimate overall prey availability. As they crawlover the bottom, crabs encounter prey one or several at a time. Prey-acceptance/ rejection sequences suggested to Elner and Hughes that:crabs have very short-term memories causing suboptimal prey to be rejected at first.but 
accepted if optimal prey are not soon encountered. They suggested that this flexible mechanism rapidly adjusts the feeding response to smallscale changes in prey availability. Holling (1965) hypothesised a similar effect; extinction of learned responses in the absence of reinforcement. Assuming that energy maximisation is a maxim of optimal foraging and that there are additional nutrient requirements in excess of calories alone, it is important to assess each potential prey of immature lobsters. Available data for the prey used in the present study or for, related species are summarised in Table 24.

In genera1, dry weight calorific values are highest for mollusces, followed by polychaetes, crustaceans, Asterias vulgariś, and sea urchins. Varying contributions of water and" shell alter the ranking of calorific values of live animals. Wet weight calorific values (of more relevance to natural predation) are high for crustaceans, moderately high for polychaetes and moderate for Asterias vulgaris and molluscs. Wet weight calorific values are very low for Strongylocentrotus $\mathrm{sp}$. In terms of other nutrient values, molluscs" and brittlestars are high in carbonate. Both crustaceans. and molluscs have relatively high levels of protein. Echifoderms; on the other hand, are low in proteins.

There is an apparent correlation between the calorific value and protein content of prey and the degree of preference of prey by immature lobsters, suggesting that energy maximisation is a characteristic of lobster foraging behaviour.' Reddin (1973) observed capture, immobilisation. ard opening, and consumption of three species of prey by adult lobsters. He determined that, while capture times were fairly variable, times of immobilisation, opening, and consumption of prey were quite similar, such that total handling time was approximately 100 minutes for each of Cancer, 
Table 24. Summary of available data on prey calorific values and miscellaneous nutrient components.

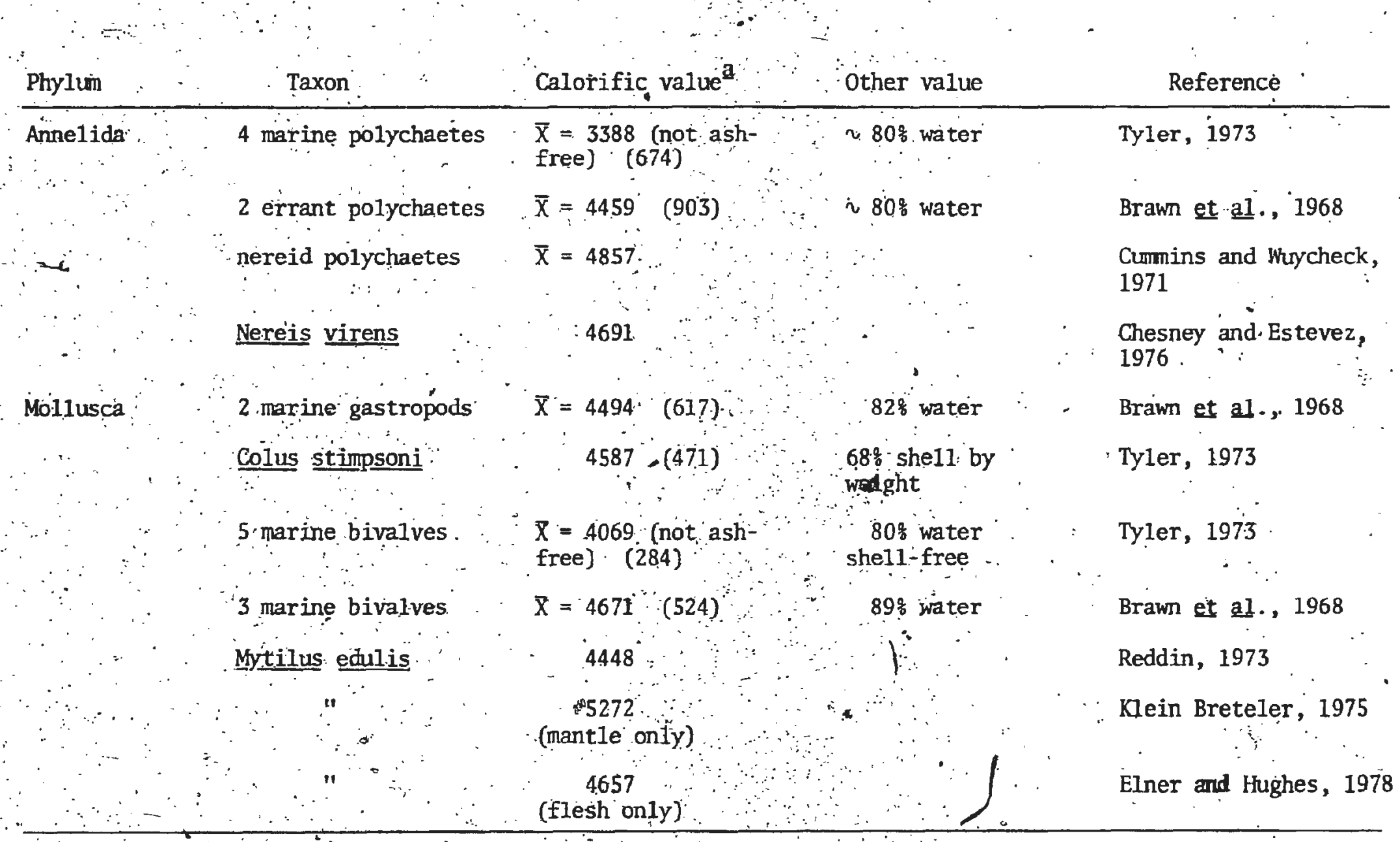

a calories/gram dry weight; calories/gram wet weight indicated in brackets

.... cont'd. 
Tabie - 24 cont a :

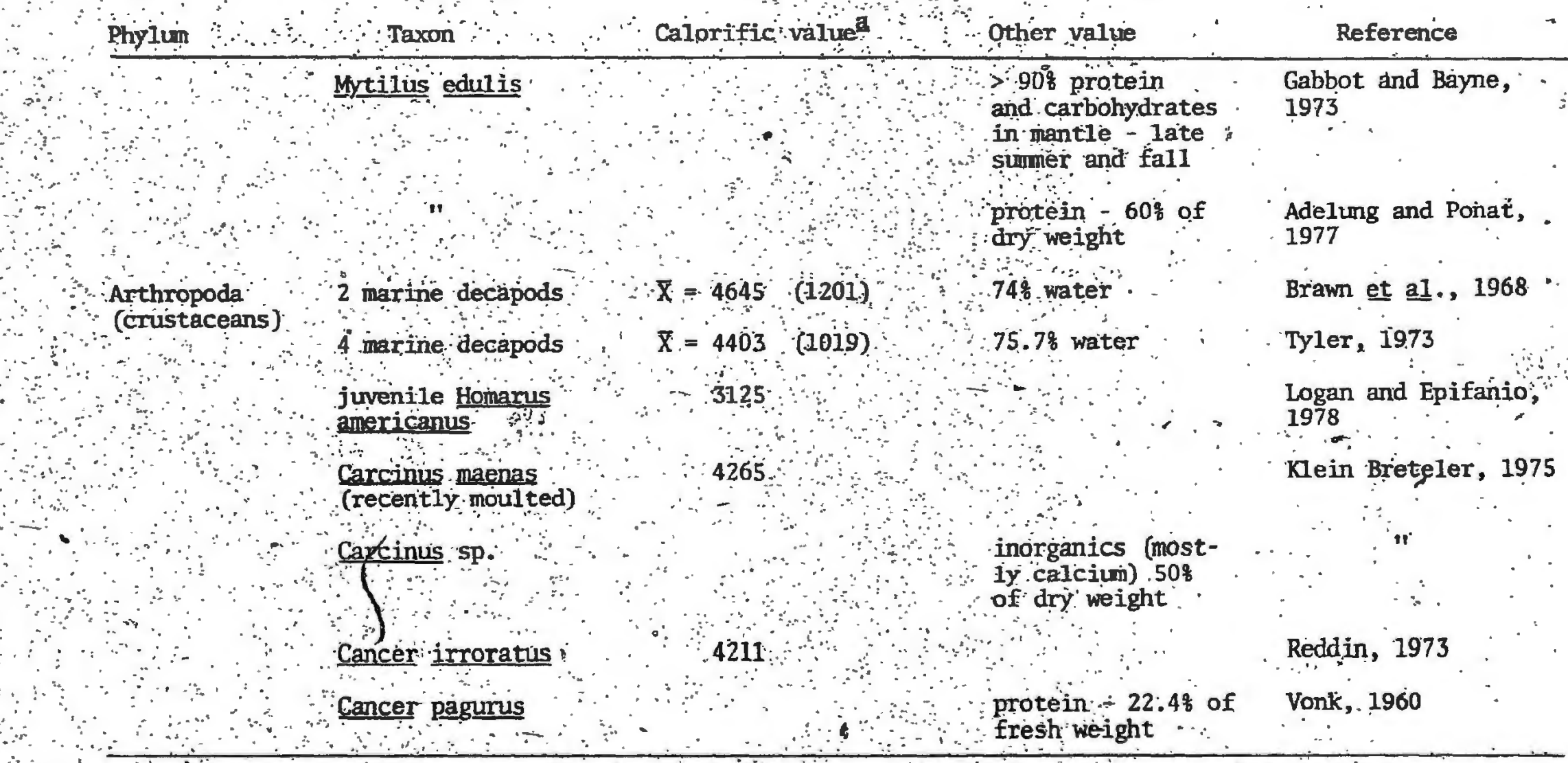

a calories/gram dry weight calories/grain wet weight indicated in brackets

cont'd. 


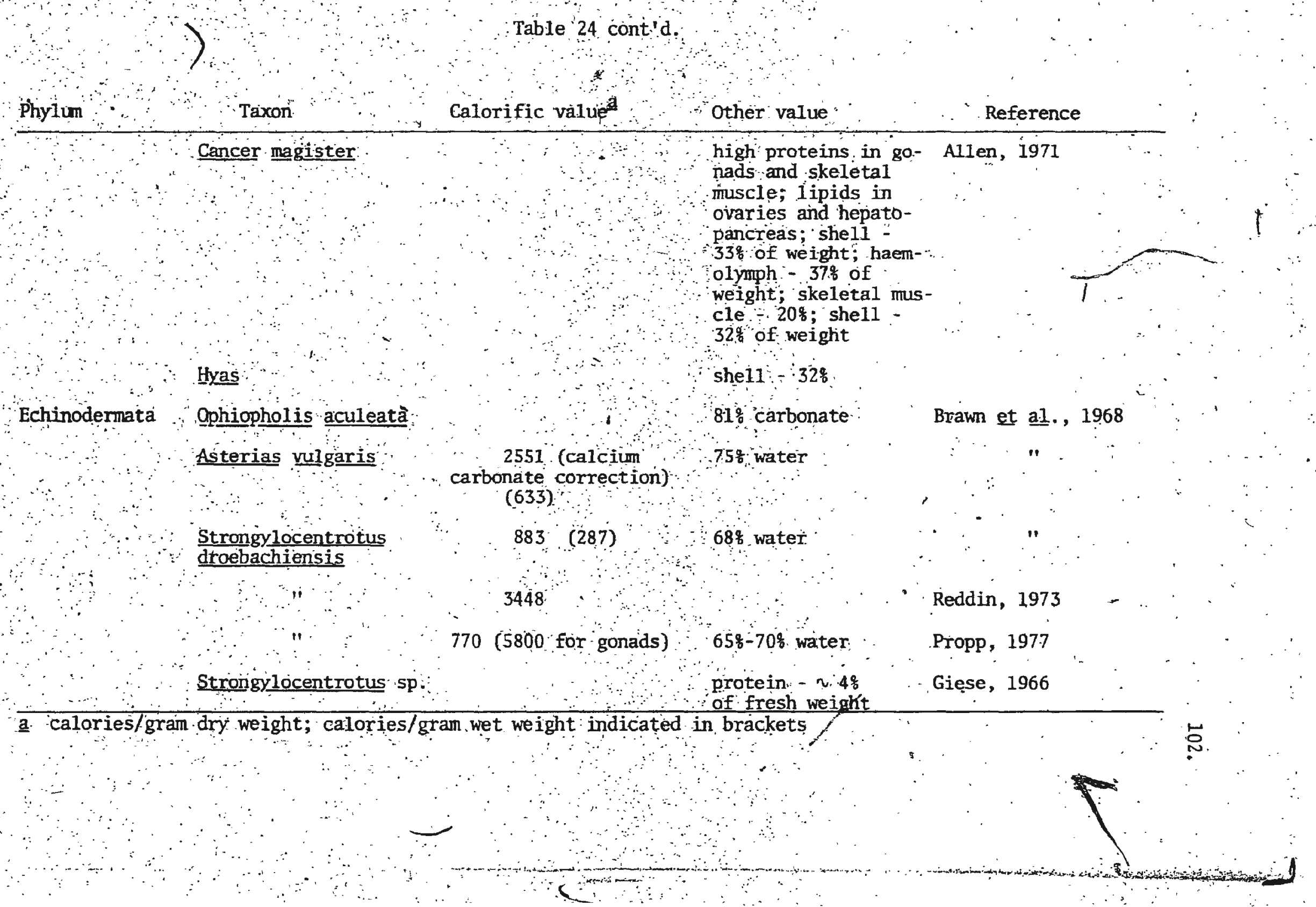


Strongylocentrotus, and Mytilus prey. A relatively long capture period for Strongylocentrotus was compensated for by a shorter consumption period. In nature, energy expense of capture of crabs may be greater than suggested by laboratory studies in which the mobility of crabs is ultimately restrained by tank walls. The relatively sessile nature of mussels and sea urchins probably makes the energy expense of capture of these prey small relative to that of crabs.

These considerations of capture expense are further complicated in nature by relative abundances of prey. If capture expense includes searching time; the cost of capture of crabs may further increase, given their infrequency in nature relative to mussels and urchins, although enhancement of the lobster -crab encounter rate is possible (this is discussed later) : Evans (1976) suggested that the calorific superiority of Cancer over other prey more than offsets the greater energy expense required to pursue and subdue this more active prey.

The actual calorific expenditure associated wi th handing time of prey by lobsters has not been calculated. Assuming that Reddin's (1973) handling times are realistic, there is probably little difference in handling expense between species: of a large size such as crabs, mussels, and sea urchins. Feeding on Asterias would probably involve a much smaller expense in handling; but the conconitant benefit in tems of calories is relatively low: Consumption of polychaetes probably involves little expense and, al though the total volume of food at each capture is small, the calorific value of polychaetes is high. Perhaps the most productive foraging technique is capture of large prey (such as Cancer and Mytilus) with high calorific value and other nutrient attributes. For example, Elner (personal communication) observed that mussels contributed approximately 
seven times more energy to the diet than sea urchins when lobsters, were given a choice of mussels and urchins.

Apart from the calorific value of prey, the apparent preference of lobsters for crustaceans has additional significance when the dietary requirements of lobsters are considered. For example, Castell and Budson (1974) demonstrated that adult lobsters have a requirement for high levels of dietary protein, and Logan and Epifanio (1978). suggested that the minimum calculated percentage of protein in food to maintain small lobsters is 17.48. The actuai minimutit is probably higher because of loss of nitrogen. in forms other than ammonia and the loss of nitrogen as glucosamine (in. chitin) at each moult . Table 24 (p. 10i) indicates that crabs can meet this protein requirement. Mason (1977) found that methionine and phenyialanine were essential in the diet of juvenile lobsters. NPC analysis of prey tissue extracts in the present study indicated greater than 10x higher levels of these amino acids in Cancer compared to levels in Mytilus: edulis ând three echinoderm species. Nereis sp. had very high levels of methionine and phenylalanine as, well. Evans (1976) stated that lobsters have requirements for the pigment, astaxanthin, and glucosamine, and that these may be satisfied by. ingestion of crustacean material:

Considering the results of the studies above, it appears that crustaceans are the most beneficial prey for immature lobsters in termis of their calorific value and other nutrient levels.

It is apparent that the prey preferences of inmature lobsters have considerable adaptive value in terms of meeting food requirements." Enlen and Emlen (1975) süggested, however, that predators must have an ability to judge energy value of individual food items in order to feed in a maximally efficient way. It seems possible that olfactory messages in 
the form of NPCs from prey provide lobsters with informafion reflecting food value.' As olfactory preference is apparently correlated to the food value of prey, natural selective pressure on the feeding behaviour of lobsters has resulted in their attraction to itens with high NPC concentrations. This is an important adaptation, given that the NPC compositions of prey to some extent refiect their own feeding modes, and, thus, their composition: i.e., camivores such as crabs have high levels of protein and NPCs, and are attractive to immature lobsters. This adaptation is also important considering that the best prey (crabs) are the least abundant of prey acceptable to lobsters.

Hunger must have an important influence on the degree to which immature lobsters respond to prey effluents. An 'olfactory threshold! the concentration of NPC stimilus above which the lobster will initiate food-searching behaviour - may operate. "Prey such as Cancer may consistently produce NPC concentrations above the threshold, assuring their at: trạctiveness to lobsters. Echinodernis probably produce NPC concentratións in their effluent below the threshold of satiated 1obsters. As the degree of food deprivation increases; the olfactory threshold is lowered such that more inferior prey may elicit food-searching responses in inumature lobsters. This threshold control of feeding behaviour may be equivalen't to the shortterm memory effect on foraging behaviour of crabs described by Elner and Hughes (1978) Regardles of whether the hunger effect on optimal foraging is accommodated by a short-tem menory or a flexible olfactory threshold, the ultimate result is the same; inclusion of suboptimal prey in the "Iobster diet with increasing hunger.

NPCs released from prey during feeding by immature Iobstérs appear to be inportant, as well, in reinforcement of feeding behaviour as 


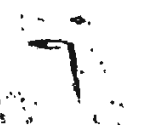


sent study and the premises of 'optimal foraging theory: "Several predatorprey interactions are hypothesised, assuming that other decapod predators such as Cancer irroratus possess olfactory abilities and feeding motivations similar to lobsters (Case, 1964; Pecci et al ., 1978):

It is assumed that inmature lobsters feed only preferred prey. when close to satiation, if they feed at all. If himger is not a strong motivation," it may be advantageous for individuals to remain in their shel-. ters and avota predation, at the same time waiting for fortuitous passing of paiathle prey which are identified by NPCs in their effluents. The scenar io of immature lobster feeding be haviour is summarised in Table 25 If a lobster is completely satiated it does not feed If the gut is not completely ful1, a lobster may start foraging Foraging commences sunset and extends throughout the night with varying intensity (Scarratt, personal commintation) Selectivity of prey ps high at the beginning of the foraging period lobsters frequently encounter sea urchins but initially do not feed on them. Similariy brittlestars are extremely common, but are generally cryptic and unatractive in terms of NPCs in effluent, and are Thinored. Most polychaetes such as nereids and polynoids are cryptic and may be difficult to capture, but considerable numbers may be moving about at night (Pettibone, 1963). Lobster encounters with polychaetes are probably com but suecessful captures less so However the handfing cost of polychaetes is low and the calorific value per unit weight is relatively high and lobsters probably atterm t capture of polychaetes on every encounter unless very close to satiation. Mussels are not as common as polychaetes, brittlestars; and urchins. Eneounters with mussels are therefore less common but, because of high food value of missels, their capture and constontion is attempted at each encounter by a less-than-sat- 
Tabie 25 ; Scenario of natural foraging of imature lobsters (it anericanus with various degrees of hunger.

-

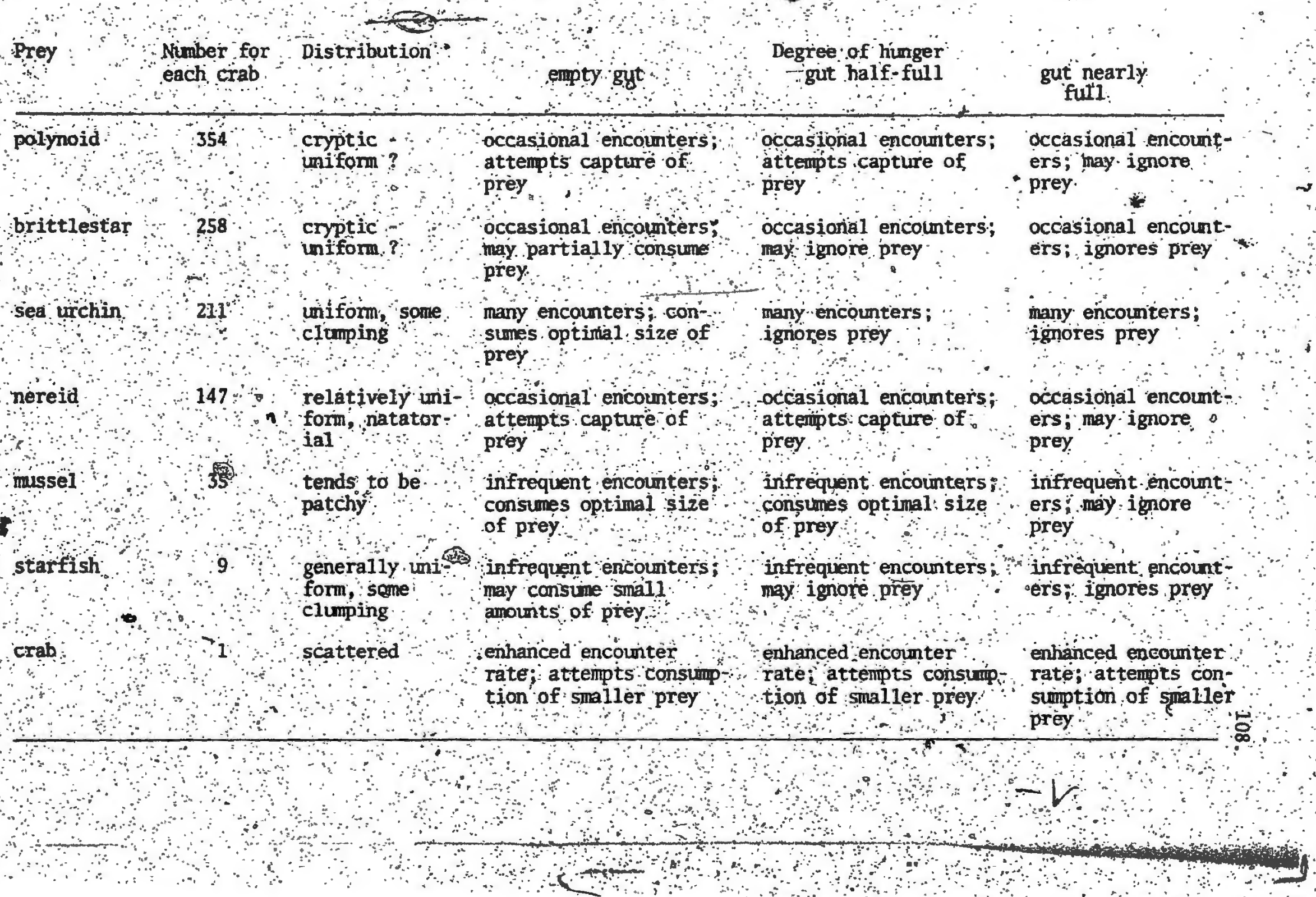


iated lobster. Lobsters feed to satiation unless disturbed or a better prey becomies available. Lobsters attempt capture of crabs on all encounters with this prey.

If the initial foraging perịod does not result in successful capture and consumption of preferred prey, the lobster is more likel $\dot{y}$ to . feed on less preferred prey as Table 25 indicates. Percentage frequencies of remaini of less preferred prey, such as sea urchin, in imature lobster guts ăre high, indicating that preferred prey species are not encountered frequently enough to preclude sea urchins from the diet.

- The percentage frequency of occurrence of crabs in immature lobsțer guts is totally disparate with crab abundance in nature (Tables 22 and 23). Random encounters of lobsters, and crabs alone cannot account for the high incidence of crabs in immature lobster guts. It is suggested that lobster feeding behaviour may enhance the lobster-crab encounter rate. As crabs have olfactory capabilities similar to 1obsters. (Case, 1964), the act of $a \cdot$ lobster feeding on a sea urchin or a mussel, which releases prey extracts, may attract crabs to the feeding site. Presumably, lobsters can also be attracted to crabs feeding on prey. There is evidence for this prey extraft reinforcement of lobster-crab encounters in nature. For example, Pecci et al. (197.8) determined that bait in lobster traps consistently attracted high numbers of Cancer irroratus, $\stackrel{i}{\mathrm{C}}$. borealis, and lobsters to the same traps: In the everit of lobster-crab encounters, a lobster may cease feeding on the inferior prey and attemipt to capture the crab. The energetic advantage of feeding on crab instead of sea urchin may be 15 t.jimes as great (Evans, 1976). Hirtle and Mann (1978) suggested that visual stimulus of food-searching behaviour through prey movement may reinforce the naturally greater attraction of lobsters to crabs over other prey, 
especially considering the high mobility of crabs compared to all other available prey. This, as well, may enhance the lobster-crab encounter. rate.

If olfactory and visuar enharicement of lobster-crab encounters does occur, much food in the form of uneaten urchins and mussels may be available to other lobsters. Apart from this, considering that lobsters feed at a rate of $1 \%-2 \%$ of their woight per day, most prey are probably only partially consumed in any case. Immature lobsters may be attracted to these partially consumed prey by olfactory information. On three occasions during the collection period, very small inmature lobsters were observed cohabiting a shelter with an adult. Such observations have been' made elsewhere in Newfoundland (Ennis, personal. communication). If a doriinance hierarchy is established such that the adult ignores the immature lobster, and lobșters consime capțred prey in their shelters as Scarratt (personal commication) suggests, much food may be available to the immature lobster, The benefits to the small lobster in terms of avoiding exposure to predation associated with foraging are corrsiderable.

Considerations of lobster habitát relationships

Lobsters are considered a key predator of the subtidal kelp zone of the rocky shores of eastern Canada (Miller et al., 1971). These authors suggested that production rates of prey species exceed the lobster ingestion rates by a factor of more than 10 and concluded that lobster production in the seaweed zone could be increased by reducing predation and competition for food and increasing suitable shelter. One of the main premises of their hypothesis was that the estimated consumption by lobsters of each 
prey species is proportional to. the production of those species. This clearly may not be the case, given the evidence of the present study and others (Evans and Mann, 1977; Hirtle and Mann, 1978) for strong prey preferences in lobsters. As well, the production model of Miller et àl. (1971) does not adequately consider the importance of Cancer in the diet of lobsters.

Mann and Breen (1972) suggested that heavy exploitation of lobsters may lead to overgrazing of seaweeds by sea urchins, with resultant loss of primary productivity. Breen and Mann (1976) tested this hypothesis.: Their model' showed that sea urchins were controlled except when lobster abundance was very low. Some chànges in the model results were observed when crabs and wolffish were added. Evans (1976). stated that this model is probably too simple ta predict the threshold abundance of lobsters necessary to keep urchins in check. Mann (1977) further suggested that the urchin-dominated barren grounds of St. Margaret's'Bay; Nova Scotia are a new; stable configuration of the ecosystem and that a long-term decrease in primary and secondary productivity of coastal waters can be expected. He suggested that destruction of the kelp beds by sea urchins leads to destruction of the habitat for young 1obsters.' Mann also suggested that, given the dietary preference for crabs shown by lobsters, crabs may have a greater importance in the ecosystem dynamics than previously thought, although Hirtle and Main (1978) suggested that urchins outnumber crabs in the diet of lobsters despite a preference for crabs.

The general concensus of most of these studies is that, while lobsters may exert a control over the sea urchin population; the degree to which this happens is difficult to determine because of lobster food preferences and predator interactions: There are no published results of 
gut content analyses of lobsters from the coast of Nova Scotia to corroborate speculations about lobster diets there (al though such studies are planned; Michaud, personal communication). As we11, the influence of immature lobsters on the kelp ecosystem has been ignored.

Results of the present study indicate that immature lobsters, while having a high incidence of small quantities of urchins in the gut, sselectively feed on crabs and mussels, and possibly" polychaetes, if the opportunity exists The head of Placentia Bay is similar to St. Margaret is ${ }^{4}$ Bay in that kelp beds are depleted (not necessarily. because of sea urchins) and urchin abundance is high; yet, substantial quantities of prey other than sea urchins exist and form an important component of the lobster diet. Electivity" indices are consistențy negative for sea urchins.. Therefore, it appears unlikely that immature lobsters will exert a great control over sea-urchin populations as long as immature lobster' numbers are relatively low and better value prey remain in the area in sufficient quantity. However, if the population of immature lobsters is increased, competition for preferred food such as crabs and mussels will be greater, and a greater number of sea urchins will be killed by lobsters.

Most of the studies of Iobster-urchin dymanics have suggested a rather direct effect of lobster fishing; that is, lobsters taken from the natural environment can no longer feed on urchins. When the effect of fishing is considered not only in terms of the predation pressure taken from the system, but alsọ in terms of the effect on the remaining lobster population, the significance of the optimal foraging aspect of lobster feeding on the urchin population is considerably greater. Specifically, it is suggested that intensive loḅster fishing in Nova Scotia in particular has had the net effect of reducing the competition between adults for 
food. Adult lobsters which are not trapped can therefore feed in an optimal way, selecting crabs and mussels to the general exclusion of sea urchins from the diet, and allowing an explosion of the sea urchin population. 


\section{'stMMARY AND CONCLUSIONS}

Results of the present study indicate that immature lobsters are more attracted to and prefer intact individuals and effluent of Cancer irroratus compared to Mytilus edulis and Strongylocentrotus droebachiensis. Ammonia and probably other ninhydrin-positive compounds released. as metabolites from intact prey can stimulate food-searching behaviour within an undefines range: Rate of capture of amionia targets by immature lobsters was significantly greater than capture rates of al1 other target types except proline. These observations, as well as the results of ninhydrin analysis showing higher concentrations of ammonia in Cancer effluent than in Mytilus and Strongylocentrotus, may explain the greater attraction of inmature lobsters to Cancer irroratus compared to other prey species.

Fidelity of attraction was maintained in tests of immature lobster behaviour elicited by prey extracts (simulating olfactory repnforcement during feeding); with ranking of behaviour variables showing the following order of apparent preference by inmature lobsters: Cancer irroratus, Mytilus edulis, Strongylocentrotus droebachiensis, Asterias vulgaris, and control. "The ninhydrin positive compound compositions of: the extracts may explain the various degrees of food-searching responses to the extracts. Cancer extract contained a much higher total NPC concentration compared to the other prey extracts and had significantly higher levels of proline: NPG target experiments showed that proline tar-" gets were captured more frequently than any other target.

Actual selection of intact prey by immature lobsters showed a higher attack rate for Cancer irroratus, compared to Mytilus and Strongyl- 
ocentrotus, although factors other than olfactory preference, such as accessibility and size of prey; may be important determinants of food selection. For the natural enviroment, where a multitude of factors determine the selection of prey by immature lobsters, Ivlev's electivity indices showed a very high selection for Cancer, moderate selection for Mytilus, and negative selection for Strongylocentrotus. Gut content analysis showed that a high percentage of the immature lobster population feeds on sea. urchins, mussels, and crabs . The guit content data in addition suggested that, at single feedings, greater anounts of crab are consumed compared to mussels and sea urchins. Controlled selection experiments and gut content analysis also revealed the potential importance of smal prey such as brittlestars and polychaetes in the diet of inmature lobsters.

The consistent attraction of immature lobsters to prey with high calorific and protein levels indicates that they probably forage in an optimal way, maximising energy and various nutrients per unit foraging time.

Future research is required on the selection of prey by imature lobsters in the natura 1 environment to determine the decisions made by lobsters during foraging sequences, in the same manner as the study by Elner and Hughes (1978), and to test the "scenario outlined in the discussion. Such variables as hunger and prey density would have to be carefully monitored. Experiments should be devised to determine which factors such as short-term memory and a flexible olfactory threshold; are operative in the foraging behaviour of lobsters. Imature lobsters; by virtue of their probable numerical dominance over adult lobsters, may comprise a much more important component of the subtidal commuity than previously thought and deserve a greater attention in hypotheses of subtidal faumal relationships. 


\section{LIST OF REFERENCES}

Ache, B.W. 1972. Amino acid receptors in the antennules of Homarus americanus. Comp. Biochem. Physiol. 42A: 807-811.

Adelung, D., and A. Ponat. 1977. Studies to establish an optima1 diet for the decapod crab. Carcinus menas under culture conditions. Mar. Biol. 44: 287-292.

Aiken, D.E. 1973. Proecdysis, setal development, and molt prediction in the American lobster (Homarus americanus):' J, Fish. Res. Board Can. 30: 1337-1344.

Aldrich, J.C. 1976. The spider crab Libinia emàrginata Leach, 1815 (Dec-

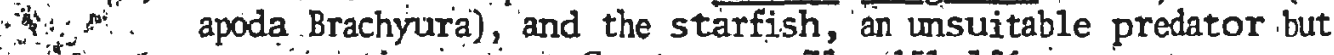
a cooperative prey." Crustaceana. 31: 151-1.56.

AMTen, w. 1971 . Amino acid and fatty acid composition of tissues of the Dumgeness crab (Cancer magister). J. Fish: Res: Board Can. 28: 1191-1195.

is P. and D.A. Dorsett. 1977. Behavioural studies on chemoreception in Balanus hameri.: Mar. Bẹav.: Physiol, 4: 205-217

Atema, if and R. B. Gagosian: $1973 . \cdots$ Behavioral responses of maie lobsters to ecdysónes. Mar. Behav. Physiol : $2: 15-20$.

Atema, J and D.G. Engstrom 1971 Sex pheromone in the Iobster Hom arus americanus - Nature $232: 261-263$

Atema, $J$ and $L: S$ Stein 1974 Effects of crude oil on the feeding behavigur of: the lobster Homarus americanus Environ. Pollut. $6:-77-86$.

Áwara, " $J_{0}$ 1962." Frèe amino acids in invertebrates: a comparative stuxdy of their distribution and mëtabolism. In Amino Acid Pools. Distribution, Formation, and Function of Free Amino Acids. Edited by J.T: Holden. Elsevier, Amsterdan: pp. 158-175.

Bayne, B.L., and C. Sculilard. 1977: Rates of nitrogen. excretion by species of Mytilus (Bivalvia: Mollusca). J. Mar. Biol. Ass. U.K. 57: 355-369;

Brawn, V.M., D.L. Peer, and R.J. Bentley. 1968. Caloric coritent of the standing crop of benthic and epibenthic invertebrates of St, Margaret's Bay, Nova Scotia.' J. Fish. Res: Board Can. 25; 18031811 .

Breen, P:A. 1974 MS. Relations among lobsters, sea urchins, and kelp in Nova Scotia: . Ph.D. Thésis. Dalhousie University, Halifax; Nova Scotilá.

Breen, P.A., and K.H. Mann 1976 Changing lobster abundance and the destruction of kelp beds by sea urchins: Mar. Biol. 34: 137142 .

Brockerhoff, H., R.J. Hoyle, and P.C. Hwang 1970, Digestive enzymes of the American lobster (Homarus americanus) : J. Fish. Res.- Board

Burikovskiy, R.N., and Y.M. Froyeman. 1974 An approach to the study of hunting by predatory marine invertebrates . Oceanology 14: 133137.

Camien, M.N., H. Sarlet, G.L. Duchateau, and M. Flórkin. 1951. Non protein amino acids in muscle and blood of marine and fresh water crustacea. J. Biol: Chem. 193. 881-885. 
Carr, W.E.S. 1967. Chemoreception in the mud snail, Nassarius obseletus. I. Properties of stimulatory substances extracted from shrimp. Biol. Bull. 133: 90-105.

Carr, W.E.S., and S. Gurin. 1975. Chemoreception in the shrimp, palaemonetes pugio: comparative study of stimulatory substances in humain serum. Biol. Bull. 148: 380-392.

Case, J. 1964. Properties of the dactyl chemoreceptors of Cancer antennarius Stimpson and C. productus Randall. Biol. Bul1. 127: 428446.

Case, J., and G:F. Gwilliam. 1961. Amino acid sensitivity of the dactyl chemoreceptors of Carcinides maenas. Biol. Bull. 121: 449-455.

Caste11, J.D., and S.D. Budson. 1974. Lobster nutrition: the effect on Homarus americanus of dietary protein Tevels, J. Fish. Res. Board Can. 31: 1363-1370.

Castel1, J.D., E.G. Mason, and J.F. Covey, 1975. Cholesterol requirements of juvenile American lobster (Homarus americanus). J. Fish. Res: Board Can. "32: 1431-1435.

Casteil1, J.D., J.C. Mauviot, and"J.F. Covey. 1976. The use of eyestalk ablation in nutrition studies with : Anerican lobsters (Homarus. americanus) $\ldots$.. In Proc 7 th Arinual Neetiong World Mariculture Socïety : Louisiana State Univ, .pp. 431-441,

Charnov; E.L. 1976, Optimal foraging:" attack strategy of a mantid. Am. Nat 110 141-151.

Chesney, E.J, Jr and JI. Esteve 2 1976 Energetics of winter floundex (Pseudopleuronectes americanus) fed the polychaete, Nereis virens, under experimentál conditions. Trans. Am. Fish. Soc. 105: 592595 .

Chesson, J, 1978. Measuring preference in selective predation. Ecology. 59: $-211-215$.

Christenisen, A:M. 1970. Feeding biology of the sea-star Astropecten "irregularis Pennant. Ophelia 8: 1-i34.

Cock, M.J.W. 1978. The assessment of preference. J.. Anim. Ecol. 47: $805-816$.

Cook; R.M., and B.J. Cockrell. 1978. Predator ingestion rate and its bearing on feeding time and the theory of optimal diets. J. Anim. Ecol. 47: 529-547.

Corne11, $\mathrm{H}_{\mathrm{t}}$ 1976. Search strategies, and the adaptive significance of switching in some general predators. Am. Nat. 110: 317-320.

Covich,. A.P.: 1976. Analyzing shapes of foraging areas: some ecological and economic theories. Ann. Rev. Ecol. Syst, 7: 235-257.

Crisp, $\therefore$ D.J.. 1967: Chemoreception in cirripedes. Biol. Bul1: 133: . 128 140 .

Cumins, K:W:; and J:C. Whycheck: 1971. Caloric equivalents-for investigations in ecological energetics. Mitt. Int. Ver. Theor: Angew. Limno1. 18: 1-158.

Dagg, M.J: "197.4. Loss of prey body contents during feeding by an aquatic predatior. Ecology 55:' 903-906.

Da11, W.: 1975.. The role of ninhydrin-positive substances in osmoregulation in the westerh rock lobster, Panulirus longipes (Milne Edwards), J; Exp. Mar. Biol Ecol. 19:' 43-58.

Daumas, R.A. 1976. Variations of particulate proteins and dissolved anino acids in coastal seawater: Mar. Chem, 4: 225-242.

Drumond-Davis', N. 1978 MS. Population estimates of the rock $\mathrm{crab}$, Cancer irroratus, in a kelp bed. and some aspects of its feeding. M.Sc. Thesis'.-Balhousie University, Halifax; Nova Scotia: 
Ebling, F.J., J.A. Kitching, L. Muntz, and C.M. Taylor. 1964. The ecology of Lough Ine. XIII. Experimental observations of the destruetion of Mytilus edulis and Nucella lapillus by crabs. J. Anim. Eco1. 33: 73-82.

Elner, R.W., and R.N. Hughes. 1978. Energy maximization in the diet of the shore crab; Carcinus maenas. J. Anim. Eco1. 47: 103-116.

Elner, R.W., and G.S. Jamieson. 1979. Predation of sea scallops, Placopecten magellanicus, by the rock crab; Cancer irroratus, and the American lobster, Homarus amerjcanus. J. Fish. Res. Board Can. 36: $537-543$.

Emlen, J.M. 1966. The role of time and energy in food preference. Am. Nat. 100: 611-617.

Emlen, J.M. , and M.G.R. Emlen. 19.75. Optimal choice in diet: test of a hypothesis. Am. Nat. 109: 427-435.

Ennis, G.P. 1973. Food, feeding, and condition of lobsters, Homarus americanus, throughout the seasonal cycle in Bonavista Bay, Newfound1and. J. Fish. Res. Board Can. 30! 1905-1909,

Ennis, G.P. 1974 MS: Observations on the lobster fishery in Newfoundland. Fish. Res: Board Can. Tech: Rep. No. 479.

Evans, P.D. 1976 MS. Choice of prey by lobsters. M:Sc: Thesis. Dalhousie University, Halifax, Nova Scotia.

-Evans, P.D. , and K.H. Mainn: 1977. Selection of prey by American lobsters (Homarus americanus) when offered a choice between sea urchins and crabs. 'J. Fish. Res. Board Can, 34: 2203-2207.

Fletcher, G.L., ,. .A. Pepper, and J.C. Kean. 1974.MS. A sttidy of the biology of the Newfoundland sea urchin with emphasis on aspects important to the development of a fishery. Mar. Sci. Res. Lab. Teck. . Rep. No. 11.

Fuzessery, Z.M., and J.J. Childress. 1975. Comparative chemosensitivity to amino acids and their role in the feeding activity of bathypelagic and littoral crustaceans. Biol. Bull. 149: 522-538.

Gabbot, P.A., and B.L. Bayne. 1973. Biochemical effects of temperature and nutritive stress on Mytilus edulis L. J. Mar. Biol: Ass. U.K. 53: 269-286.

Giese, A.C. 1966. On the biochemical composition of some echinoderms. In Physiology of Echinodermata. Edited by R.A. Boolootian. Interscience Publishers, New York. pp. 757-796.

Griffiths, 'D, '1975. Prey availability' and the food of predators. Ecology: $56 \because " 1209-1214$.

Hadley; P.B. 1912. Reactions of young lobsters determined by food stimuli. Science (N.S.) 3, 1000-1002.

Hamilton, P.V. 1976. Predation on Littorina irrorata (Mollusca: Gastropoda) by Callinectes sapidus (Crustacea: Portunidae). Bull. Max̣. Sci. 26: 403-409.

Hanmen, 'C.S. 1968. . Aminotransferase activities and amino acid excretion of bivalve mollusks and brachiopods. Comp. Biochem. Physiol. 26: 697-705.

Hartman, H.B., ard M.S. Hartman. 1977. The stimulation of filter feeding in the porcelain crab Petrolisthes cinctipes Randall by amino acids and sugars. Comp: Biochem. Physiol. 56A: 19-22.

Herrick, F.H.' 1895. The American lobster: a study of its habits and development. Bul1."U.S." Fish. Comm. 15: 1-252.

Himmelman; J.H. : 1969 ,MS.. Some aspects of the ecology of Strongylocentrotus droebachiensis in eastern Newfoundland. M.Sc. Thesis. Memorial University of Newfoundland, .St. John's, Newfoundland. 
Himmelman, J.H., and D.H. Steele. 1971'. Foods and predators of the green sea urchin Strongylocentrotus droebachiensis in Newfoundland waters. Mar. Biol. 9: 315-322.

Hindley, J.P.R. 1975. The detection; logation and recognition of food by juvenile banana prawns, Penaeus merguiensis de Man. Mar. Behav. Physio1. 3: 193-210.

Hirtle, R.W.M.', and K.H. Mann. 1978. Distance chemoreception and vision in the selection of prey by American lobster (Homarus americanus) . J. Fish. Res. Board Can. 35: 1006-1008.

Hoffman, R.S., P.J. Dumham, and P.V. Kelly, 1975. Effects of water temperature and housing conditions upon the aggressive behavior of the 1obster Homarus americanus. J. Fish. Res. Board Can. 32: 713,-717.

Ho1ling, C.S: 1965. The functional response of predators to prey density and its role in mimicry and population regulation. Entomol. Soc. Can. Mem, 45: 1-60.

Holling, C.S. 1966; The functional response of invertebrate predators to prey density. Entomol: Soc. Can. Mem. 48: 1-86.

Hoiling, C.S.; R.L. Dunbrack; and L.M. Dili. 1976. Predator size and prey size: presumed relationship in the mantid Hierodula coarc tata Saussure. Cán. J. Zool. 54: 1760-1764.

Hughes, R.N. 1979.: Optimal diets under the energy maximization premise: the effects of recognition time and leaming: Am; Nat. 113: $209^{-2}-221$.

Ivlev, V.S. I961. Experimental ecology of the feeding of fishes. Eng1 ish translation by $D$ : Scott. 'Yale. University;Press, New Haven," Conn.

Johnson, B.R:', and B.W. Ache. 1978. Antennular chemosensitivity in the spiny lobster, Panulirus argus: amino acids as feeding stimuli. Mar. Behav. Physiol. 5: 145-157.

Katz, P.L. 1974. A long-term approach to foraging optimization. Am. Nat. 108: $758 \div 782$.

Kennedy, D., and M.S. Brumo. 1961. The spectral sensitivity of crayfish and lobster vision. J. Gen. Physiol. 44: 1089-1-102,

Kittredge, J.S., D.G. Simonsen, E. Roberts, and B. Jelinek. 1962. Free amino acids of marine invertebrates. In Amino Acid' Pool's. Distribution, Formation, and Function of Free Amino Acids. Edited by J.T. Holden. Elsevier, Amsterdañi. pp: 176-186.

K1ein Breteler, W.C.M. 1975. Food consumption, growth and energy metabolism of juvenile shore crabs, Carcinus maenas: Neth. 'J. Sea Res. 9: 255-272.

Laverack, M.S. 1962a. Responses of cuticular sense organs of the lobster, Homarus vulgaris (Crustacea) - - I. Hair-peg organs as water cur -" rent receptors: Camp: Biochem. Physiol. 5: 319-325.

Laverack, M.S. 1962b.. Responses of cuticular sense organs of the 1obster, Homarus vulgaris (Crústacea) - - II. Hair-fan organs as pressure receptors. Coy̆p. Biochem. Physio1, 6: 137-145.

Laverack, M.S. 1964. The antennular sense organs of Panulirus argus. Coimp. Biochen. Physiol. 13: 310-321.

Lehninger, A.L. 1975. Biochemistry, the molecular basis of cell structure and function. 2nd. ed. Worth Publishers Inc., New York.

Levaridowsky, M., and E.S. Hodgson. 1965: "Amino acid and amine receptors of 1obsters. Comp. Bíchen. Physiol. 16: 159-161.

Lindstedt; K:J. 1971. Chemical control of feeding behavior, Comp. Biochen: Physiol. 39A: 553-581: 
Logan, D.T., and C.E. Epifanio. 1978. A laboratory energy balance for the Iarvae and juveniles of the American lobster Homarus americanus. Mar. Biol.. 47: 381-389.

Mackie, A.M. 1973. The chemical basis of food detection in the lobster Homarius gammarus. Mar. Biol. 21:-103-108.

Mackie, A.M., and R.G.J. Shelton. 1972. A whole-animal bioassay for the determination of the food attractants of the. lobster Homarus gammanus, Mar. Bíol. 14: 217-221.

Manin, K.H. 1977. Destruction of kelp-beds by sea-urchins:- a cyclical phenomenon or irreversible degradation? Helgol. wiss. Meeresunters 30: $455-467$.

Mann, K.H., and P.A. Breen. 1972. The relation between lobster abundance, sea urchins, and kelp beds, J. Fish. Res. Board Can. 29; 603609.

" Marten, G.G... 1973. An optimization equation for predation: Ecology 54: $92-101:$

Mason, E.G. . 1977 MS . Dietary amino, acid requirements of juivenile lobs ters (Homarus americanus): M.Sc. Thesis: Daihousie University, Halifax, Nova Scotia.

Meister, A. 1965 Biochemistry of anino acids Vol 1 and ed: Academic Press Inci. Néw York.

Méglitsch, P.A. 1972. Invertebrate zoology." 2nd, ed. Oxford Unịversity Press, New York:

Miller, R.J., K.H. Mann, and D.J. Scarratt. 1971. : Production potential: of a seaweed-lobster community in eastern Canada. J...Fish." Res. Board Can.' 28:' 1.733-1738.

Miner, R.W. 1950. Field Book of Seashore Life: G.P. Putman's and Sons, New York.

Muntz, L.,.F.J. Ebling, and J.A. Kitching. 1965. The ecology of Lough Ine. ' XIV. Predatory activity of large crabs." J. Anim.. Ecol , $34: 315 \div 329$

Murdoch, W.W. . 1969: Switching in general predators: experiments on predator specificity and stability of prey populations. Ecol. Monogr. 39: 335-354.

Murdoch, "W.W. 1973. The functional response of predators. J. App1. Eco1. 10: $335-342$.

McBurney, D.R., ; and D.G. Wilder. 1973 MS. Survịval and condition of -1ob-' sters in a tide pond related to feeding, cover and stock density." Fish." Res. Board"Can. Tech."Rep. No: 377.

McLeese, D.W. 1970: Detection of dissolved substances by the American lobster (Homarus americanius) and oifactory attraction between lobsters. J. Fish. Res. Böard Can $77 \%$ 1371-137.8.

Mcleese, D.W. 1972a MS. Initial experiments on the growth of the American lobster in captivity. Fish. Reśs. Bäard Can. Tech. Rep. No. 320.

Mcleese, D.W. 1972b. Effects of "several factors on the growth of the American lobster (Homanus americanus.) in captivity....J. Fish. 'Res. Board Can. $29: 1725-1730$.

Mcleese, D.W. ' 1.973á. Response of lobsters Homarus americanus to odor solution in the presence of bleached kraft:mill effiuent: $\mathrm{J}$. Fish. Res. Board Can. 30: : 279-282.

Mcleese, D.W.: 1973b: Orientation of lobsters (Homanus americanus) to odor. J: Fish. Res. Board Can." 30: 838-840.

McLeese; DiW. $1973 \mathrm{C}$.". Olfactory responses of lobsters (Homanus americanus) to solutions fram prey species and to seawater extracts and chemical fractiónis of fish muscle and effects of antenule ablation. Mar. Behav. Physiol. 2: 237-249: 
McLeese, D.W., R.L: Spraggins, A.K. Bose, and B.N. Pramanik. 1977. Chemical and behavioral studies of the sex attractant of the lobster (Honarus americanus). Mar. Behav: Physiol. 4: 219-232.

Nakamura, Ko: 1974. A model of the functional response of a predator to prey density involving the hunger effect. Oecologia 16: 265278.

Natrella, M.G. 1972. The relation between confidence intervals and tests of significance. In Statistical Issues. Edited by R.E. Kirk. Brooks/Colé :Publishing Co., Monterey, Calif. pp. 113'-117.

Norberg, R.A. 1977. An ecological theory on foraging time and energetics and choice of optimal food-searching method. J. Anim. Ecol. $46: 511-527$ :

Oaten; A., and W.W. Murdoch. 1975.. Switching, functiona1 response, and stability in predator-prey systems. Am. Nat. 109: 299-318:

-Paine, R.T. 1976. Size-1imited predation an observational and experi-: mental approach with the Mytilus-pisastef interaction $\therefore$ Ecology $57 \div 858-873$.

Patterson, M.K Jr. 1972 Uptake and utilization of amino acids by cei1 cultures, In Growth; Nutrition and Metabolism of Cel1s in Culture. Vol 1 Edited by G.H. Rothblat and V:J Cristofalo: Acádemic Press Inc. New York pp: $171-209$

Pecci, K.J R.A.:Cooper, C:D. Newel1, R.A. Glifford, and R.J. Smolowitz: 1978 Ghost fishing of vented and unvented Lobstèr, Homarus

$\because \because \quad \therefore$ americanus, traps Mar Fish. Rev. 40, 9-24.

Peterson, $\mathrm{C} . \mathrm{H}:$, and B.P. Bradley. 1978. Estimating the diet of a sluggish predator from field observations. J. Fish. Res. Board Can. 35: . $136 \div 141$.

Pettibone, M.H. 1963. Marine polychaete worms of the New England region: 'I. Aphrodi tidae through trochochaetidae: U.S. Nat, Mus. Bull. $227:$ Part. 1 .

Pollock, D.E: 1979. Predator-prey relationships between the rock lobster Jasus lalandij and the musse1 Aulacomya ater at Robben: Island on the Cape West Coast of Africa. Mar: Biol: 52: 347-356.

Price, R.B., and B.W: Ache. 1977, Poripheral modification of chemosensory information in the spiny lobster. Comp. Biochem. Physio1: 57A: $249-253$.

Propp, M.V. 1977. Ecology of the sea urchin Strongylocentrotus droebachiens is of the Barents. Sea: metabolism and regulation of abiundance. Biologiya Morya 1: $39-51$.

Puilian, H.R 1974, Of the theory of optimal diets. Am. Nat 108: 59 7.4.

Pullịam, H:R. $\because$ 1975. Diet optimization with nutrient constraintș. Am. Nat. i09: $765-7.684$

Pyke, G.H., H.R :Pulliam, and E.L Charnov. 1977 Optimal foraging: a selective review of theory and tes, ts. Q. Revi. Biol, 52: 137-154:

Rapport, D.Jk 1971: An optimization mode1 of food selection. Am. Nat. $105:$ : $575-587$.

Rapport, "D.J.; and J.E. Turner 1970. Determination of predator, food preferences J. Theor Biol: 26: 365-372.

Reddin, D. 197.3. MS. - The ecology and feeding habits of the American lobster (Homarus américanus (Milne-Edwards, 1837)) in Newfoundland. M.Sc. Thesis. Menorial University of Newfoundland, St: John's; Newfoundland. 
Richard, P. - 1977. Influence de la temperature sur les acides aminés iibres de Palaémon sérratus et P. squilla. Bịochem, Syst. Eco1. 5: 297-300.

Riley, J.P:, and D.A. Segar. :1970. The seasonal variation of the free. and combined dissolved anino acids in the Irish Sea J. Mar.

- Biol, Ass. U.K. 50: "713-720.

Roesijadi, G., J.W. Aniderson, and C.S. Giam.. 1976. Osmoregulation of the grass. shrimp palaenonetes pugio exposed to polychiorinatęd biphenyls (PCBs). II. Effect on free amino acid's of muscle tissue. "Mar. Biol. 38: 357-363.

Scarratt, D.J., and R. Lowe. 1972: Biology of rock crab (Cancer inroratus) in Northumberiand Strait. J. Fish." Res. Board Can. 29: 161-166"

Schoener, 'T.W. 1969:" Models of optimal size for solitary predators. Am. Nat, $103: 277-313$

- Schoener, T.W. 1971. Theory of feeding strategies. Annu. Rev Écol Syst. . $2: 369-404$.

Schoffeniels, E., and $R$; Gilles, 1970. Nitrogenous constituents and nitrogen metaboli ism in arthropods. In Chemical Zoology. Vol . 5: Part A. "Edited by M: Florkiñ and B.T. Scheer: Acadenic Press Inc New York pp. 199-227.

Scrivener, J.C.E. 1971 MS, Agonistic behaviour of the American lobster Homarus americanus (Milne-Edwards) $\therefore$ Fish. Res. Board Can Tech. Rep. No. 235 .

Shelton; R.G.J., and A.M. Mackie. 1971. Studies on the chemical preferences of the shore crab, Carcinus maenas -(Li): J.: Exp. Mar. Biol. Ecol: $7: 41-49$,

Shepheard, P. 1974. Chemoreception in the antenule of the lobster, Homarus americanus .: Mar. Behav. Physiol. 2: 261-273.

Siebers, D., C. Lucu, K. R. Speri.ing, and $K_{\text {. }}$-Eberlein. 1972. Kinetics of osmoregulation in the crab Carcinus maenas. Mar. Bio1. 17: $291-303$.

Snow, P.J. 1973. The antennula activities of the hermit crab pagurus alaskensis (Benedict) $\therefore$ J. Exp. Biol. 58: 745-765.

Sokal, R.R., and F.J -Rohlf. 1969: Biometry - the principles and practice bf statistics in biological research. W.H. Freeman and Co., Sán Francisco.

Squires. H.J 1970. Lobster (Homanis americanus) fishery and ecology in Pört au Port Bày, Newfoundland, 1960-65: Proc. Nat: Shellfish." Ass, 60: $22-39:$

Squires, H.J., and G.P. Ennis, 1968. Lobsters from 95 fath deep off St. John's, Newfoumdland. J, Fish. Res. Board Can, 25: 2723-2724:

Stenseth, N.C., and L. Hansson. 1979: optimal food selection: a graphic mode1. Am. Nat. 113: 373-389:

Swiss, J.J., and J.M. Osborne 1976 MS. Baseline characteristićs of Come by Chance Bay, Newfoundland: Enviromerital Protection Service Surveillance :Rep.- No: EPS-5-AR-76-9.

Tazaki, K.. 1977. Nervous responses ifrom mechanosensory hairs on the antennal flagelium in the lobs ter; Homarus gamarus (L.) $\because$ Mar. Behav. Physiol: 5: "1-18.

Templeman, $W$. 1940. The life history of the lobster Dept of Nat Res. (Nfld. Gov't.) Service Bul1 15 .

Torres, C. 1973. Variations du pool 'des acides amines libres tu muscle abdominal de Penaeus kerathurus au cours du cycle d'intermue, et au cours du' jeune Comp . Biochem . Physiol 45B $1-12$. 
Tyler, A.V. 1973. Caloric values of some North Atlantic invertebrates. Mar. Biol. "79: 258-261.

Vadas, R.L. 1977. Preferential feeding: an optimization strategy in sea urchins, Ecol. Manogr. 47: 337-371.

Vonk, H.J. 1960. Digestion and metabolism. In The Physiology of Crustacea. Vol. 1. Edited by T.H. Waterman: Academic Press Inc., . New York. pp. 291-316.

Wachtendonk, D. von, and M. Käppler. 1977. Amino acids and biogenic amines in smooth muscles and hemolymphs of different molluscs. Comp. Biochem. Physiol. 56C: 19-24.

Webb, K.L., and R.E. Johannes. 1967. Studies of the release of dissolved free amino acids by marine zooplankton. Limno1. Oceanogr. 12: 376-382.

Weber, R.E., - and W.J.A. van Marrewi.jk. 1972. Free amino acids in the shrimp Crangon crangon and their osmoregulatory significance. Neth. J. Sea Res. 5: 391-415.

Weiss, H.M. 1970 MS. The diet and feeding behaviour of the lobster, Homirus americanus, in Long Island. Ph.D. Thesis. University of Connecticut, Storrs; Connecticut.

Werner, E.E., and D.J. Hall. 1974. Optinal foraging and the size selectivity of prey by the bluegi-l1 sunfish (Lepomis macrochirus). Ecology 55: 1042-1052.

Westoby, M. 1978. What are the biological bases of varied diets? Am. Nat. 112: 627-631.

Windhoiz, M: (ed.), S. Budavari (assoc. ed.), L.Y. Stroumtsos (asst. ed.), and.M.N. Fertig (tsst. ed .). 1976. 'The Merck. Index. An Encyclopedia of Chemicals and Drigs. 9th ed Merck and Co. " Inc.; Rahway, New Jersey:

Zafiriou, 0. 1972. Ręsponse of Asterias vilgaris to chemical stimuli. Mar. Biol, 17: 100-107.

Zeitlin-Hale, L., and A.N. Sastry, 1978. Effects of environmental mani- pulation on the locomotor attivity and agonistic behavior of cultured juvénile American lobsters, Homarus americanus. Mar. a Biol. 47: 369-379. 
APPENDIX A

Individual lobster data at time of collection.

Collection Location Wet weight Carapace Sex Lab. exper- Gut content date length iments analysis

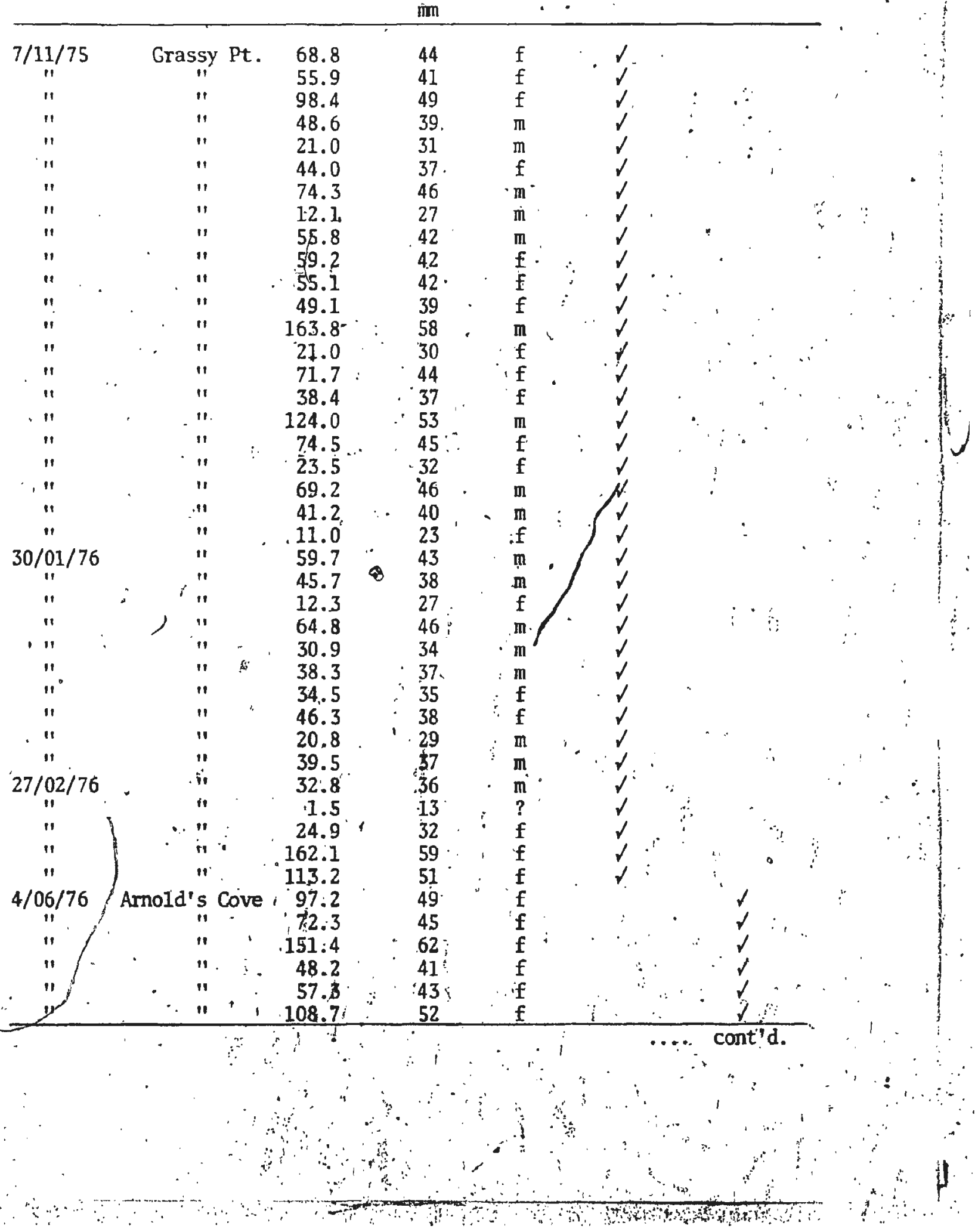




\section{APPENDIX A cont'd.}

Collection Location Wet weight date

$$
\mathrm{g}
$$

Carapace Sex length
Lab. exper + iments
Gut content analysis

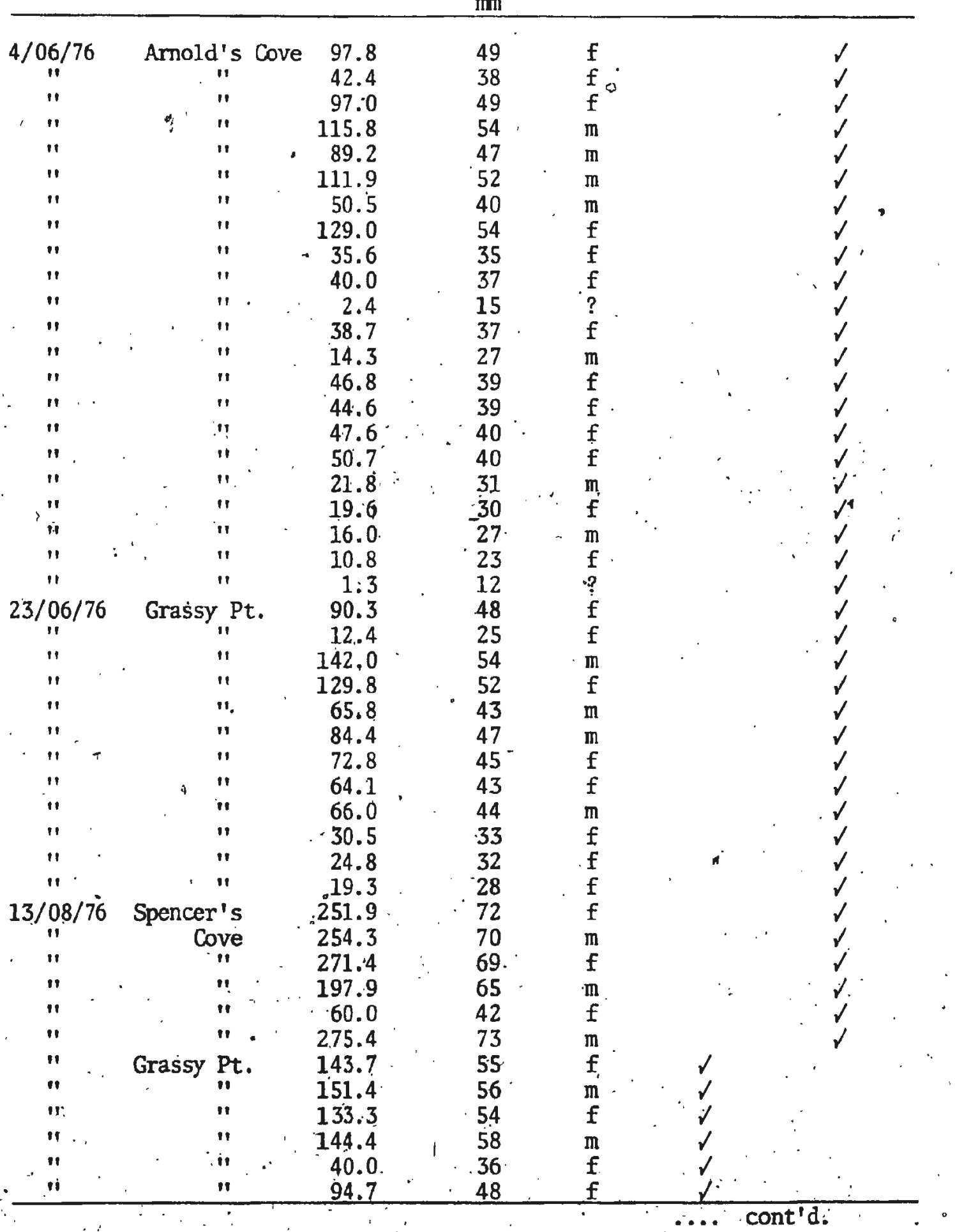


126.

APPENDIX A cont'd.

Collection Location Wet weight Carapace Sex Lab. exper-Gut content date

$\mathrm{g}$ length iments analysis

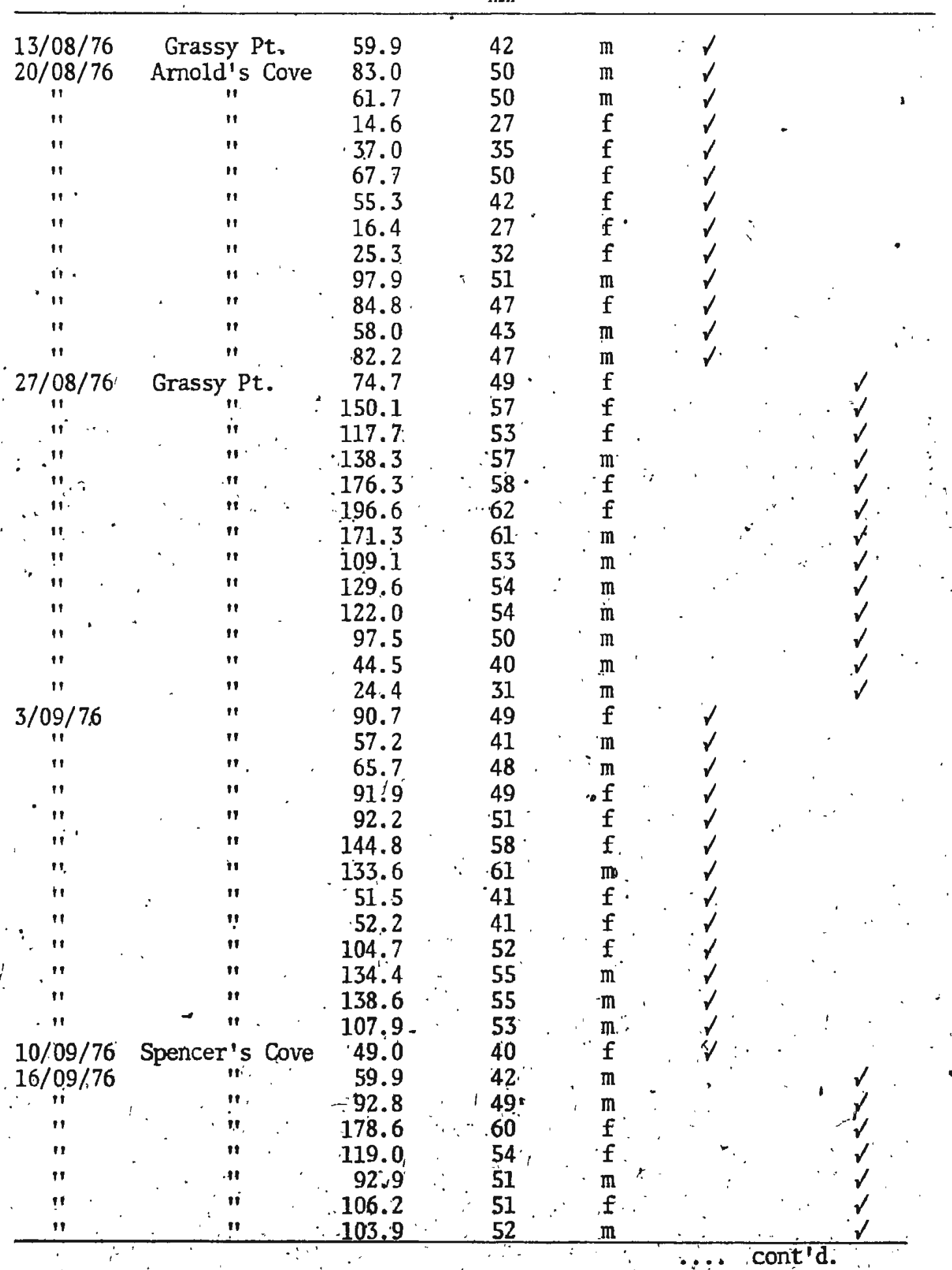


APPENDIX A cont'd.

Collection Location. Wet weight Carapace Sex Lab. exper-Gut content date

$\mathrm{g}$ length

$\mathrm{mm}$. iments analysis

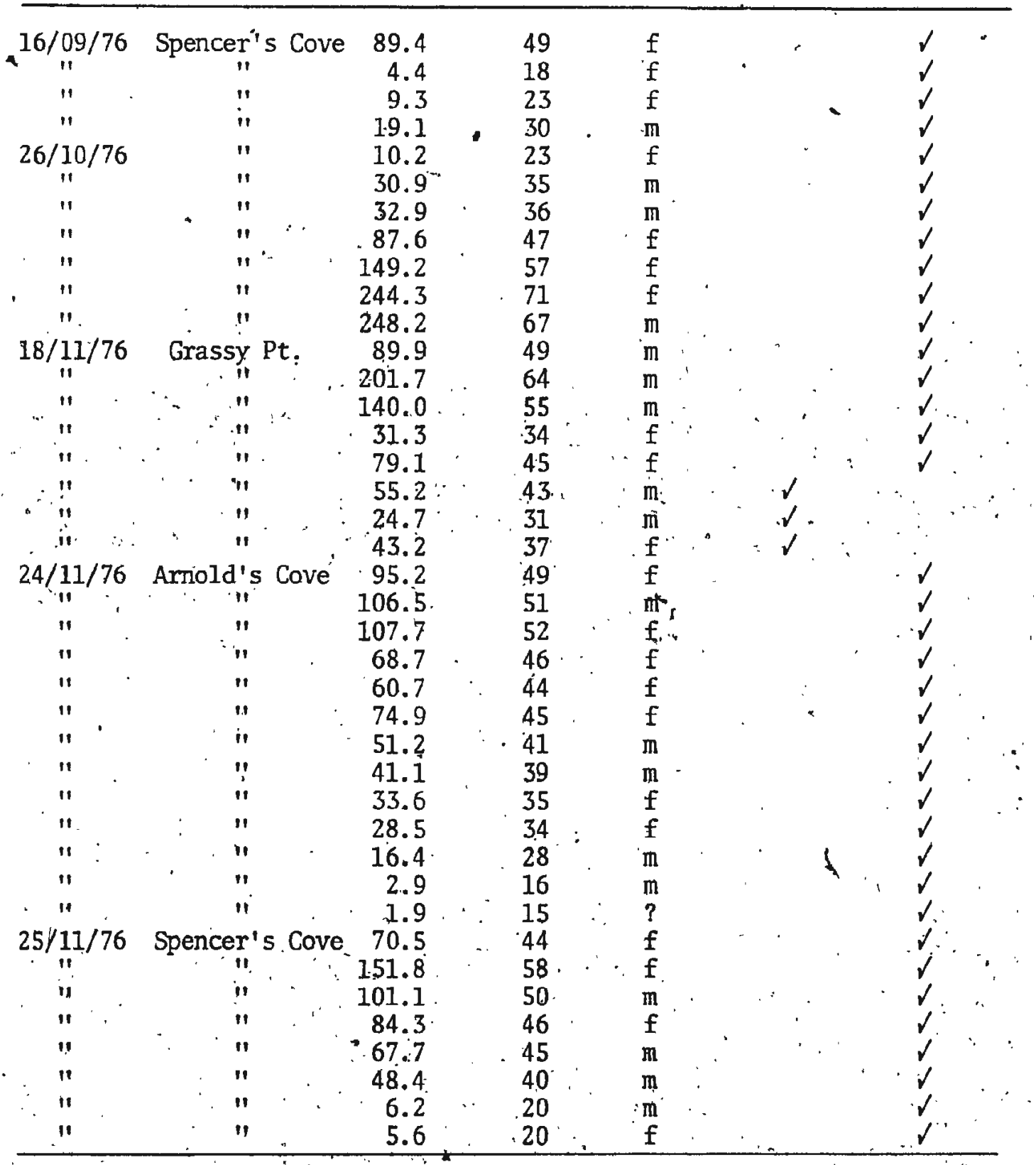




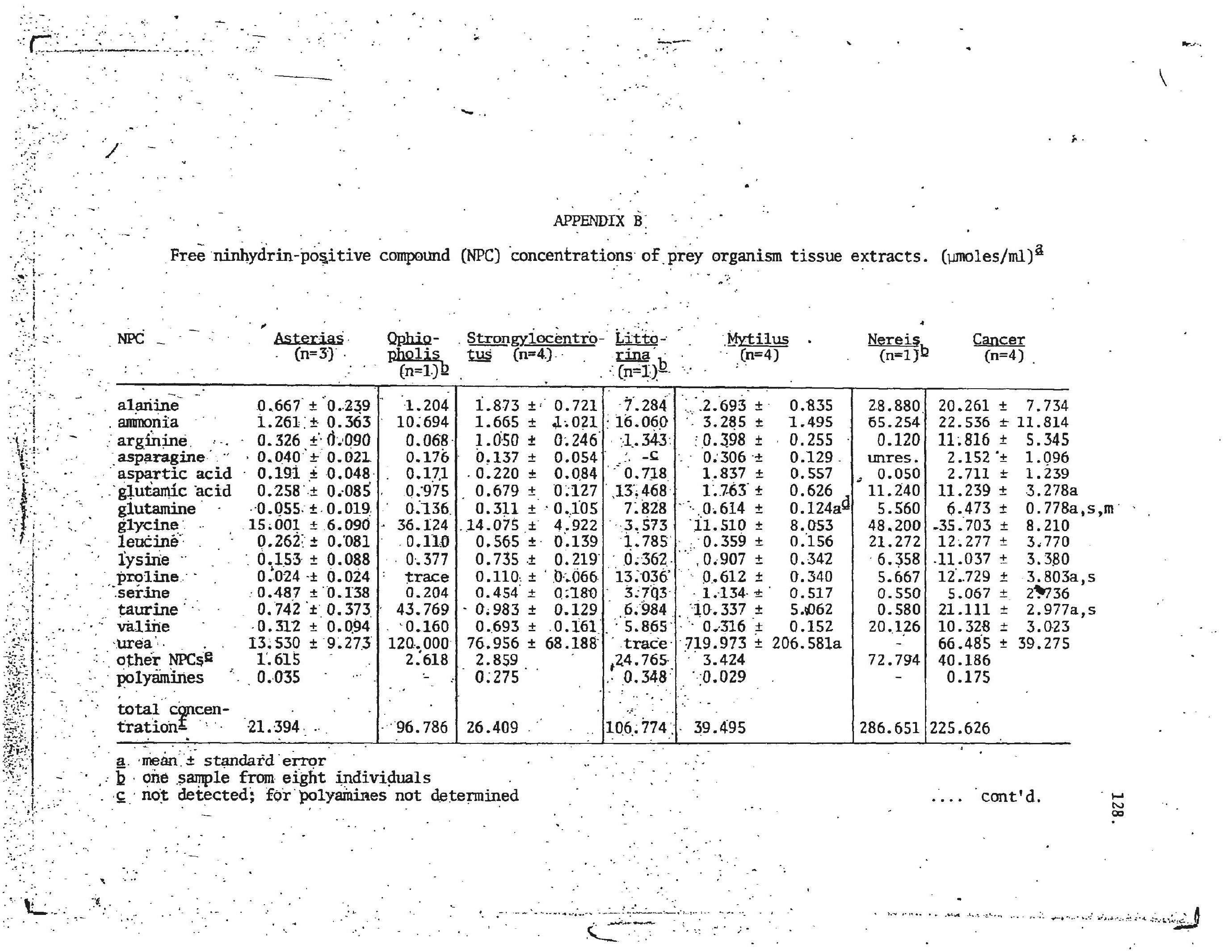


APPENDIX B cont'd.

d. significantly greater than:' a - Asterias; s - Strongylocentrotus; m - Mytilus, $p<0.05$

e $\beta$-alanine, $\alpha$-amino ądipic acid, $\alpha$-amino $n$ butyric acid, $\beta$-amino isobutyric acid, $\gamma$-amino butyric acid, anserine, citrulline, cystathiorijine, cysteic acid/phosphoserine, half cystine, ethanolamine, reduced".glutathione, glycerophosphoethanolamine, histidine, hydroxylysine, hydroxypraline, isoleucine, methionine, methionine sulphoxide, 3-methylhistidine, ornithine, phenylalanine, phosphoethanolamine, sarcosine, threonirie, tryptophan, tyrosine

f excluding urea, unknowns, trace amounts, and polyamines 


\section{APPENDIX C}

Gut items of immature lobsters (Homarus americanus) - characteristic hard parts.

Prey organism

Characteristics

Cancer irroratus

fragments of carapace with characteristic pigmentation; portions of pereiopods; pereiopod tips very common; claw knuckles common; apodemes occasional; parts 'of maxillipeds and maxillae; eyes; gilizs; parts of antennae occasional

Hyas araneus portion of pereiopod

Pagurus arcuatus characteristic claw and portions of pereiopods

unidentified crustacean usually heavily worn or digested portions of cara-"? pace and peretopods

Nereis sp. jaws extremely comon, frequently numerous in a single gut; denticles connon; setae extremely common; acicula common; occastional complete parapodium; peristomial cirri occasional

polynoid polychaete jaws extremely common, frequently numerous in a single gut; , elytra very common; denticles occasional; peristomial cirri occasionai; frequently portions of body intact.

unidentilied polychaete oniy settae evident amphipod portion of body.with large coxal plates.

chiton. shell valyes intact .7

sponge

Lacuna vincta some tissue with spicules portions of characteristic shell occasional; opercula conmon

Littorina 1ittorea portions of she11 common; thick characteristic

Lora bicominata opercula common

Margarités costalis complete shèl1 complete sheli. unidentified gastropods small portions of abraded shell $1 i^{\circ}$ cont $! d$. 
Prey organism

Characteristics

Anomia aculeata

Hiate11a arctica

Mitilus edulis

Tellina agilis

unidentified bivalve

Asterias vulgaris

Ophiopholis aculeata portions of characteristic shell

one complete valve

portions of shell; periostracum extremely com-

mon; bysisus threads occasional

, complete set of valves

portions of abraded she11 comon

calcareous portions of arms occasional

calcareous vertebrae of arms common; small arm spines common

Strongylocentrotus droe bachiensis

bryozoan mon; pedicellaria occasional; portions of jaws occasionaí

zóecia with spines occasional 
Percentage of immature lobsters (Homarus americanus) from Placentia Bay in various moralt stages.

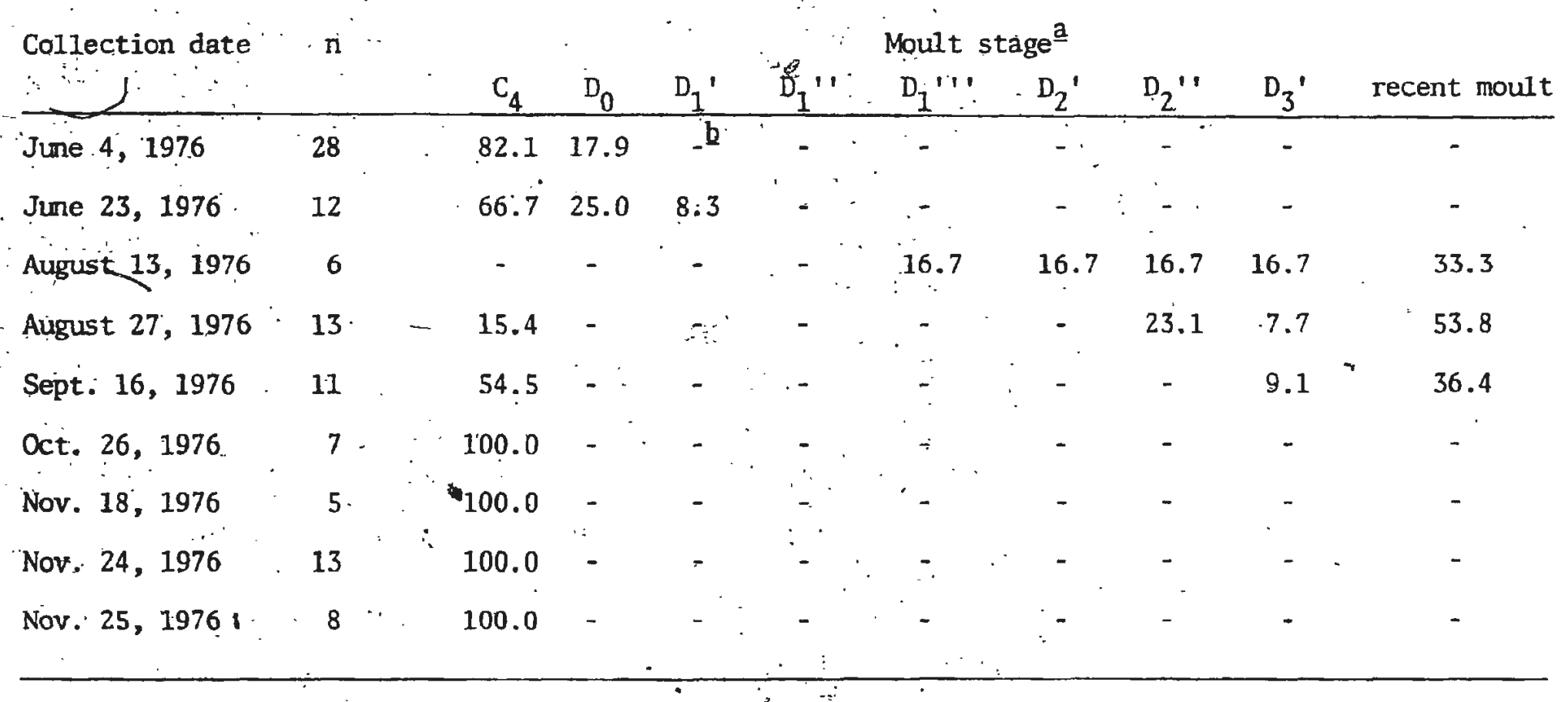

a moult stage classification according to Aiken, 1973.

$\underline{b}$ no lobsters in this stage observed 


\section{APPENDIX E \\ Considerations of gut content analysis}

Gut analysis based on indicator particles has been criticised by Reddin (1973). He suggested that this method is invalid for determining diet since lobsters do not seem to actively consume shells except at moult. This Iatter statement is inaccurate. In all cases of inmature lobsters feeding on ad libitum diets of Cancer irroratus, Mytilus edulis, and Strongylocentrotus droebachiensis, enough sheli or test wạs consumed by lobsters to be readily detected in the guts: While Reddin's criticisms of the 'indicator' technique of gut analysis are not strictly ap: plicable, some important points or assumptions inherent in the method are raised.

In the first instance, the sources of indicator fragments are either active predation of live prey or incidental/deliberate ingestion of shell fragments from the bottom. Laboratory experiments show that ingestion of shell is common during feeding on crabs, mussels, and sea urchins, and ingestion of small hard parts is very probable in the case of feeding on polychaetes and brittlestars, considering their size and morphology. An indeterminable proportion of prey hard parts may originate from the guts of lobster prey such as crabs and polychaetes, but this must be small. Deliberate ingestion of shell fragments appears to be common in post-moult lobsters. The high number of mollusc, species in immature lobster guts and the low individual species occurrence support this hypothesis.

1 Several other factors may influence the percentage frequency of occurrence of prey species in immature' lobster guts and the percentage 
of guts in which a single species is dominant. These are sumarised below.

Factors which may bias values for incidence of prey items in immature lobster guts

Percentage frequency of occirrence of items in lobster guts:

1. The probability of ingestion of indicator parts of a particular prey species.

2. The length of residency of indicator parts in a lobster gut.

3. Real differences in the percentages of the lobster population feeding on various prey species.

Percentage frequency of occurrence as dóminant gut item:

1. The differential rate of ingestion of indicator parts; i.e., for a species A, there may be a greater probability of consuming more indicator parts thä for a species $B$.

2. The length of residency of indicator parts in the lobster gut; i.e., - there may be a net accumulation of hard parts of a particular species to the point of dominancy in the gut

3. Sequence of feeding on various species; i.e., a species A was consumed more recently than a species $B$ and therefore is dominant in the gut. This is related to gut clearance times.

4. Assuming an equal çhance of consuming indicator parts, more of one species was consumed than any other individual species. 
In terms of the percentage frequency of occurrence of species in immature lobster guts, factor 1 will probably cause little bias of results. Results of the present study show a definite ingestion by immature lobsters of prey hard parts, regardiess of the species, Presence of a species was noted regardless of the relative quantities of hard parts.

Factor 2 has been suggested by. Burokovskiy and Froyerman (1974) ' and Peterson and Bradley (1978) as a source of error in determination of diets of predators. 'They defined residence time as the period of time $>$ during which the prey item remains recognisable in the gut. Those prey species with characteristicaliy long average residence times will tend to be overrepresented among the gut contents Christensen (1970) noted that in the gut contents of an asteroid Astropecten irregularis, the residence times of gut items differed by a factor of more than 50 , substantialiy biasing the determination of feeding proportions. Two indications in the present study reduce the possibility of factor 2 influencing the value of incidence of prey itemis. Observations of guts of inmature lohsters deprived of food or fed diets of cod and liver showed that prey hard parts, regardless of the species, were capable of remaining in the gut for long periods. For example, parts of all the major prey species could remain in lobster guts for at least 10 days, albeit in progressively smailer quantities as the period of food deprivation increased. There were no obvious trends indicating that parts of some prey were more likely to have longer gut residence times than other prey, with the possible exception of Asterias. and Strongylocentrotus with apparently shorter residence times SecordIy, the gut evacuation rates of hard parts from sea urchin, crab, and mussel are apparenty quite similar, substantial clearance of the guts oc- 
curring by the third or fourth day after feeding. In the case of lobsters feeding on Ophiopholis, parts of the brittlestar arms were observed in the faeces within one day after feeding. Brockerhoff et a1 (1970) found that, lobsters fed chopped mackerel and held at temperatures of $9^{\circ} \mathrm{C}$. to $12^{\circ} \mathrm{C}$. had guts free of food particles on the third day after feeding and that gastric juice was clear by-the fifth day.

Assuming that factors $I$ and 2 do not significantly bias percentage frequencies of occurrence of prey in immature lobster guts, then the third factor, rea1 differences in the proportion of the lobster population feeding on prey, must be the factor with the greatest influence on percentage frequency of occurrence of gut items.

Several factors may influence the recorded percentage frequency of occurrence of dominant gut items. Factor 1 in the previous sumary may influence dominancy values. Two prey species of equal mass may have different quaritities of hard parts. For example an ingested nereid would probably contribute fewer hard parts in the gut of an inmature lobster than an inges ted crab. Aithough the same quantity of tissue may be ingested, the gut would show-a greater contribution of crab parts to the total volume of gut contents However, the influence of factor 1 is mininised if capture of the 1obster to be exanined occurs soon after ingest ion of its last meal, before significant digestion of the soft tissues has occurred. For example in the case of polychaetes being dominant in the gut, considerable quantities of soft tissues with associated hard parts were observed. Table 19 (p 58 ) indicates that-Fäctor 1 has a neglogible effect on dominancy values when comparing diets of Cancer; yytilus, and Strongylocentrotus:

Factor 2 probably has little influence on percentage frequencies of occurrence fôr reasoins stated above (lengths of residency of items in 
inmature lobster guts are similar). Assuming that gut clearance rates are approximately the same regardless of prey species, and that factor 1 does not have a profound effect on recorded occurrence values, the last species consumed before capture of the lobster will probably be the dominant item in the gut. Experiments in the laboratory indicated that last meals always contributed the greatest proportion to the total volume of gut items, at least within eight days of the last feeding. If factor 3 is generally operative, then the values for dominancy of gut items can be considered equivalent to the percentages of the population feeding on certain species just before capture. Factor 4 probably has a real effect on dominancy values as well. 'If more of one species is consumed than. other individual species during a single feeding period such as one night; then that species will be dominant in the gut. This is intuitively obvious: 




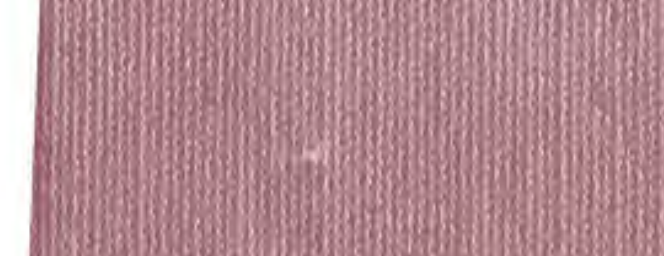

